Review

\title{
Pulp and paper mill sludge management practices: What are the challenges to assess the impacts on greenhouse gas emissions?
}

\author{
Patrick Faubert ${ }^{\mathrm{a}, *}$, Simon Barnabéb ${ }^{\mathrm{b}}$, Sylvie Bouchard ${ }^{\mathrm{a}}$, Richard Côtéa ${ }^{\mathrm{a}}$, Claude Villeneuve ${ }^{\mathrm{a}}$ \\ a Chaire en éco-conseil, Département des sciences fondamentales, Université du Québec à Chicoutimi, 555, boulevard de l'Université, Chicoutimi, Québec, \\ Canada G7H $2 B 1$ \\ ${ }^{\mathrm{b}}$ Chaire de recherche industrielle en environnement et biotechnologie, Département de chimie, biochimie et physique, Université du Québec à \\ Trois-Rivières, 3351, boul. des Forges, C.P. 500, Trois-Rivières, Québec, Canada G9A 5H7
}

\section{A R T I C L E I N F O}

\section{Article history:}

Received 29 June 2015

Received in revised form 8 January 2016

Accepted 11 January 2016

Available online 6 February 2016

\section{Keywords:}

Biosolid

Climate change

Landfilling

Land application

Energy recovery

Life cycle analysis

\begin{abstract}
A B S T R A C T
Pulp and paper mill sludge (PPMS) is an organic residual generated from the wastewater treatments. PPMS management involves economic, environmental and social costs that will likely increase in the future as landfilling tends to be reduced or banned in certain jurisdictions. The reduction or the banning of landfilling may be considered as a climate change mitigation measure since organic waste disposal is normally associated with greenhouse gas (GHG) emissions. This critical review aims to (1) describe the variety of the current and emerging PPMS management practices that are alternatives to landfilling and (2) underline the crucial need for GHG emission assessments. The management practices of the three main PPMS types (primary, secondary and de-inking) comprised in this review are land application (agriculture, silviculture, land reclamation and composting), energy recovery (combustion, anaerobic digestion, pyrolysis, bioethanol, hydrogen production and direct liquefaction) and integration in materials (biocomposite, cement, asphalt and adsorbent-absorbent). Future research should focus to increase the comprehension of known GHG determinants from the PPMS management practices and reveal unknown factors. Life cycle analyses, based on direct GHG emission measurements, are needed to determine GHG emissions from current and emerging practices and plan a responsible future reduction or banning of landfilling. Such analyses will contribute to assist decision makers in implementing the best PPMS management practices with the least impact on climate change.
\end{abstract}

(C) 2016 Elsevier B.V. All rights reserved.

\section{Contents}

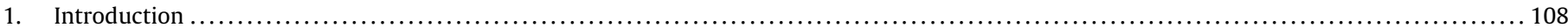

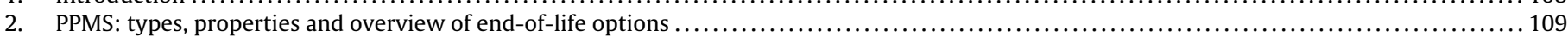

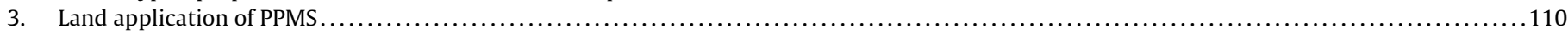

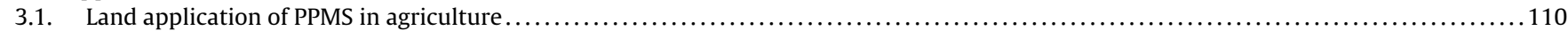

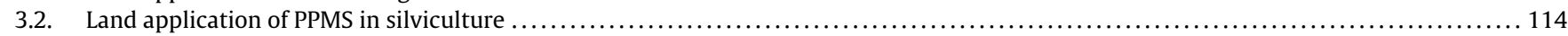

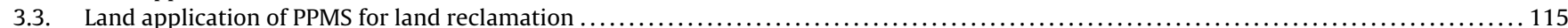

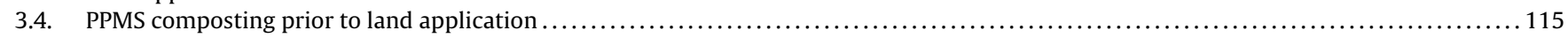

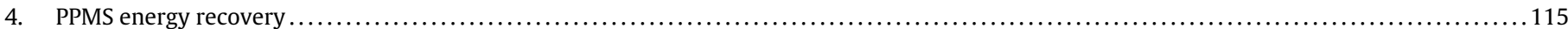

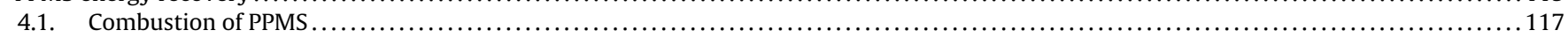

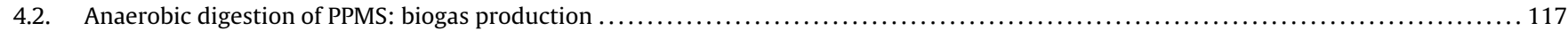

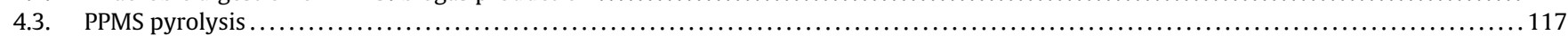

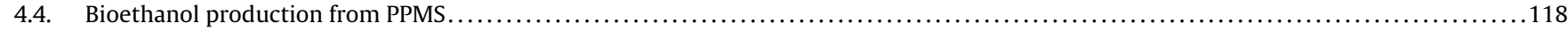

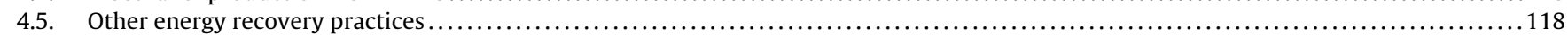

\footnotetext{
* Corresponding author.

E-mail address: patrick1_faubert@uqac.ca (P. Faubert).
} 


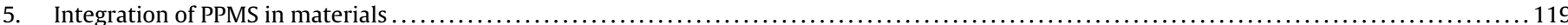

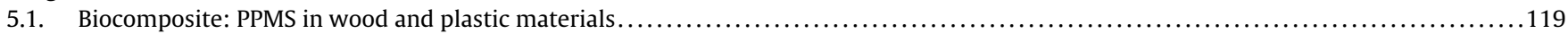

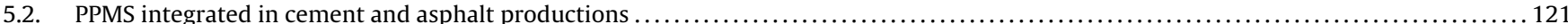

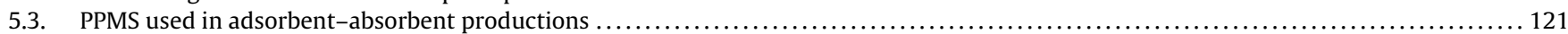

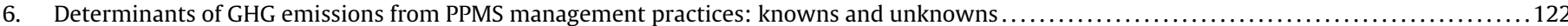

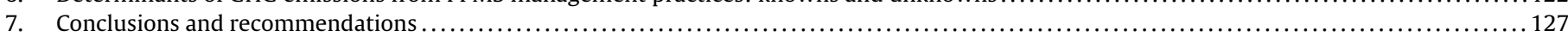

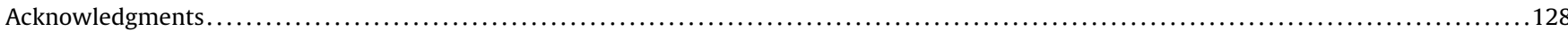

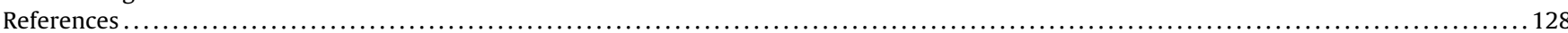

\section{Introduction}

Pulp and paper mill sludge (PPMS) is the main organic residual generated from the wastewater treatments of the pulp and paper industry. The annual world production of paper and paperboard is estimated to 400 million tons (FAOSTAT, 2015) and is predicted to reach up to 550 million tons by 2050 , which could increase the PPMS production by $48-86 \%$ compared with the actual rates (Mabee and Roy, 2003). PPMS management and disposal involve economic, environmental and social costs that will likely increase in the future. Some jurisdictions actually tend to reduce or ban landfilling of organic residuals by improving the efficiency of resource use and recycling (Council of the European Communities, 1991; US EPA, 1994; Ljunggren Söderman, 2003; EC-BiPRO, 2007; Fytili and Zabaniotou, 2008; Monte et al., 2009; MfE, 2010; MDDEP, 2011; Gouvernement du Québec, 2012), which will likely induce a change in the actual management practices (Mabee and Roy, 2003; Pervaiz and Sain, 2015). The actual greenhouse gas (GHG) emissions from the variety of PPMS management practices are unknown and should be addressed especially in the light of upcoming changes, consequence of reducing or banning landfilling.

The actual and common PPMS management practices are landfilling, land application for agricultural, silvicultural and reclamation purposes, and energy recovery through combustion (CANMET, 2005; Camberato et al., 2006; Gavrilescu, 2008; Likon and Trebše, 2012; MDDELCC, 2015; Pervaiz and Sain, 2015). The proportions of PPMS directed to one of these practices vary with time and jurisdiction policies. For instance, in the U.S., up to $87 \%$ of PPMS was landfilled in 1979 (Amberg, 1984) whereas this proportion has now decreased to 52\% (Pervaiz and Sain, 2015). Nowadays in the province of Quebec, Canada, the annual production of 1.4 million tons of PPMS are managed at $29 \%$ by landfilling, $31 \%$ by land application, $35 \%$ by energy recovery and $5 \%$ by other practices (MDDELCC, 2015). The Quebec's government policies aim to ban landfilling of PPMS by 2020 (MDDEP, 2011; Gouvernement du Québec, 2012) resulting in major challenges for the industry to change their PPMS management practices in order to meet the government objectives. The practice of landfilling will also tend to decrease in other jurisdictions following the application of such policies and pressure from the low public acceptance (Wang et al., 2008; Joo et al., 2015; Pervaiz and Sain, 2015). Depending on the local context for each paper mill, the tonnages actually directed to landfill sites may not be only manageable by current energy recovery installations and land availability. Energy recovery through combustion benefits to pulp and paper industry (e.g., heat and electricity production) but it can be costly due to the implantation of combustion facilities and the prior PPMS dewatering process (CANMET, 2005; Mahmood and Elliott, 2006; Xu and Lancaster, 2008). Land application is generally feasible (Camberato et al., 2006; Pervaiz and Sain, 2015) and well accepted but this option can be practically and economically difficult for certain paper mills. For instance, some paper mills are located at great distances from agricultural lands, leading to high management costs and GHG emissions related to transport. Moreover, the heavy metal contents of some types of PPMS and the odor, especially when the spreading is done in the vicinity of residential areas, can be environmental and public acceptance issues in rare exceptions (Rashid et al., 2006; Pervaiz and Sain, 2015).

There is a need to integrate novel PPMS management practices as land application and/or energy recovery through combustion may not be the common alternatives to dispose the PPMS tonnages actually directed to landfill sites. Several alternative management options, other than combustion for energy recovery, are emerging, such as anaerobic digestion for biogas production, pyrolysis and bioethanol production (Monte et al., 2009; Meyer and Edwards, 2014). PPMS can also be integrated as a component of biocomposites, bioplastics, cement and asphalt, as well as being used for adsorbent-absorbent productions (Beauchamp et al., 2002; Mari et al., 2009; Monte et al., 2009; Li et al., 2011; Yan et al., 2011; Likon and Trebše, 2012; Almquist and Qin, 2013; Soucy et al., 2014; Pervaiz and Sain, 2015). These emerging options also have the potential of being opportunities for industrial synergies, leading to mutual economic benefits. The residual of one industry becomes the primary matter for another industry, fitting with the concept of industrial ecology.

The reduction or the banning of PPMS landfilling could represent a potential abatement for GHG emissions, especially in North America (Fischedick et al., 2014). So far, the GHG emissions from PPMS landfilling have only been theoretically estimated (1 ton of landfilled low-ash PPMS could release 2.69 tons of $\mathrm{CO}_{2}$ and 0.24 ton of $\mathrm{CH}_{4}$ due to aerobic and anaerobic decomposition; Buswell and Mueller, 1952; Likon and Trebše, 2012) and robust data series from direct GHG measurements are non-existent for different landfill conditions and mill operations (NCASI, 2005; IPCC, 2006). The GHG emissions from wastewater treatment plants can be estimated with models and life cycle analyses (Ashrafi et al., 2013a, 2013b, 2015; O'Connor et al., 2014; Zang et al., 2015) but the emissions from PPMS management are unknown outside the mill operations. The impacts on climate change from the pulp and paper industry can also be estimated through its GHG emissions using calculation tools such as the one built by the National Council for Air and Stream Improvement (NCASI, 2005). However, data from direct GHG emission measurements that isolate the contribution of PPMS management practices on the GHG emission budgets are missing in the NCASI calculation tool and are not considered in the guidelines of the Intergovernmental Panel on Climate Change (IPCC) for national greenhouse gas inventories (IPCC, 2006). Therefore, direct measurements linked to various PPMS management practices could be used in databases such as the Ecoinvent database utilized by the SimaPro software for example (Ecoinvent, 2013; PRé Consultants, 2014), or to build models similar to the biosolids emissions assessment model (BEAM) that estimates GHG emissions from municipal biosolid management (SYLVIS, 2009; Brown et al., 2010).

This review aims to describe the variety of the actual and emerging PPMS management practices that are alternatives to landfilling. Moreover, the objective is to underline that GHG emission assessments from PPMS management practices are needed to: 
Table 1

Physical and chemical properties of primary, secondary, mixed (primary-secondary) and de-inking pulp and paper mill sludge (PPMS).

\begin{tabular}{|c|c|c|c|c|c|}
\hline Parameter & Primary PPMS & Secondary PPMS & Mixed PPMS & De-inking PPMS & References $^{c}$ \\
\hline Dry matter $\left(\% \mathrm{FM}^{\mathrm{a}}\right)$ & $15-57$ & $1-47$ & $19-60$ & $32-63$ & $1-23$ \\
\hline Ash content (\% dry solids) & $10-15$ & $10-20$ & 20 & $40-60$ & 8,13 \\
\hline Nitrogen $\left(\% \mathrm{DM}^{\mathrm{b}}\right)$ & $0.045-0.28$ & $1.1-7.7$ & $0.7-3.6$ & $0.15-1.0$ & $1-3,6,7,9-13,15-17,19-28$ \\
\hline Phosphorus (\% DM) & $0.01-0.06$ & $0.25-2.8$ & $0.22-0.74$ & $0.0012-0.16$ & $1-3,7,9,11,12,15-17,19,20,22,25-28$ \\
\hline Potassium (\% DM) & $0.02-0.09$ & $0.078-0.7$ & $0.03-0.33$ & $0.0029-0.2$ & $1-3,7,9-11,15-17,19,20,22,26-28$ \\
\hline $\mathrm{C}: \mathrm{N}$ ratio & $111: 1-943: 1$ & $8: 1-50: 1$ & $13: 1-31: 1$ & $34: 1-344: 1$ & $1-3,6,9-11,15-17,19-31$ \\
\hline $\mathrm{pH}$ & $5.0-11.0$ & $6.0-8.5$ & $3.8-8.1$ & $7.2-9.2$ & $1-3,5-7,9-12,14-16,19-22,24-26,28,32$ \\
\hline Heating value (MJ kg-1 DM) & 5.5 & $0-25$ & $14-19$ & $1.5-5.7$ & $8,12,23$ \\
\hline
\end{tabular}

a Fresh matter.

b Dry matter.

c References: 1 - Aitken et al. (1998); 2 - Simard et al. (1998); 3 - Charbonneau et al. (2001); 4 - IPPC (2001); 5 - Calace et al. (2003); 6 - Allahdadi et al. (2004); 7 -

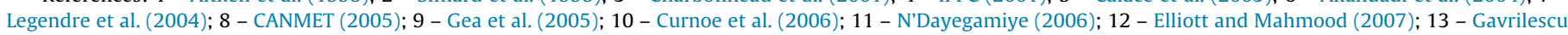

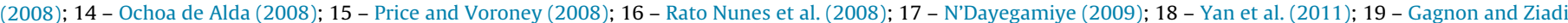

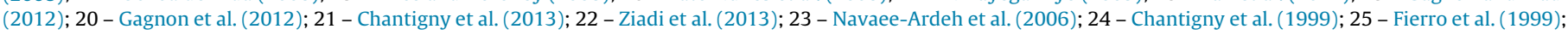

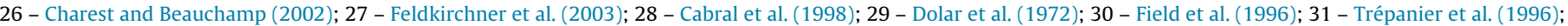
32 - Méndez et al. (2009b).

- Determine the impacts of the current scenarios that are actually unknown, as well as from the future scenarios in which landfilling will not be possible.

- Build upcoming approved protocols that could be used in a cap-and-trade program such as the one of the Western Climate Initiative (WCI) aiming to reduce and offset industrial GHG emissions.

\section{PPMS: types, properties and overview of end-of-life options}

Pulp and paper production requires large amounts of water, ranging between 15 and $100 \mathrm{~m}^{3} \mathrm{Mg}^{-1}$ dry pulp, used as reaction media and wash water (Ackermann et al., 1999; IPPC, 2001; CANMET, 2005; Ashrafi et al., 2015), which effluent needs to be treated before being released to the environment. PPMS is the organic residual material remaining after wastewater treatment in the pulp and paper mills. Three main types of PPMS are produced: primary, secondary and de-inking (Thompson et al., 2001; Pokhrel and Viraraghavan, 2004; CANMET, 2005; Mahmood and Elliott, 2006; Monte et al., 2009). Primary and secondary PPMS are often combined in different ratios (Pervaiz and Sain, 2015) to form "mixed" PPMS (Table 1; the term "mixed PPMS" is used hereafter as a combination of primary and secondary PPMS). In rare cases, PPMS and municipal biosolids can be combined (Gagnon et al., 2010) but this type of PPMS is not documented in this review. Properties of the main types of PPMS are summarized in Table 1; studies show that these can be quite variable. Pulp and paper manufacturing processes are of five main types: mechanical (i.e., grinding and refining processes), chemical (i.e., Kraft and sulfite processes), chemo-mechanical (i.e., batch and continuous systems), thermomechanical and paper making (CANMET, 2005; Ashrafi et al., 2015). Thus, the variability in the PPMS properties reflects the quality and composition of the wastewater effluents that are, up to a certain extent, particular to each mill depending on the type of raw material and input, paper making process and wastewater treatment (CANMET, 2005; Pervaiz and Sain, 2015). However, certain properties such as the ash content, carbon:nitrogen ratio (C:N) and heating value can be used to characterize each type of PPMS (Table 1).

Primary PPMS is the residue from the primary treatment with high fibrous and organic contents (i.e., high $\mathrm{C}: \mathrm{N}$ ratio, Table 1 ), consisting mainly of a mixture of coarse and fine fibers and fillers obtained by gravity through a primary clarification process (CANMET, 2005; Pervaiz and Sain, 2015). Wastewater treatments leading to primary PPMS are mainly physicochemical consisting of sedimentation and floatation (Thompson et al., 2001; Pokhrel and Viraraghavan, 2004; CANMET, 2005).
Secondary PPMS (also called biological sludge, biosludge or waste activated sludge - WAS) is the residue left after the biological treatment of the wastewater, where microorganisms are used to reduce the charge in dissolved organic matter, chemical oxygen demand and biochemical oxygen demand (Thompson et al., 2001; Pokhrel and Viraraghavan, 2004; CANMET, 2005; Mahmood and Elliott, 2006). The amount of secondary PPMS generated is less than that of primary PPMS as all the residual cellulosic fibers and inorganic materials are removed by the primary clarification process (CANMET, 2005). Nitrogen, phosphorus and oxygen must be added to the process to maintain microorganism activity, which explains the low C:N ratio and high phosphorus content (Table 1). The most common treatment leading to secondary PPMS is aerobic (e.g., activated sludge process), aeration is performed into basins, tanks, ponds or lagoons containing aerobic bacteria that decompose and remove organic substances (Thompson et al., 2001; Pokhrel and Viraraghavan, 2004; CANMET, 2005). Water effluents resulting from the secondary treatment and clarification process do not need any further treatment and are usually released to the environment (CANMET, 2005). Existing or emerging technologies can control and reduce the quantity of secondary sludge from pulp and paper mills (Mahmood and Elliott, 2006), which could decrease the amount of PPMS to manage. However, more research would be needed to enhance these reduction technologies and their common utilization by the industry (Joo et al., 2015). Primary and secondary PPMS are often combined to be dewatered by a mechanical process, and further disposed or recycled by different means (Table 1).

Paper recycling produces de-inking PPMS which is a combination of the viscous float or scum created by the dissolved air floatation process used to remove inks and dyes from recycled paper fibers and the primary and secondary clarification processes (CANMET, 2005). De-inking PPMS contains fibers, inorganic compounds such as ink particles (color pigments), de-inking agents, adhesive components and fillers (e.g., kaolin, clay and calcium carbonate; CANMET, 2005; Gavrilescu, 2008; Monte et al., 2009). Heavy metals and mineral contents of de-inking PPMS are high whereas heating values are typically low (Table 1; CANMET, 2005; Rashid et al., 2006). De-inking PPMS is usually characterized by a high C:N ratio explained by the high organic content of wastepaper (Table 1).

PPMS contains some heavy metals, which can be an environmental issue regarding their disposal (IPPC, 2001; CANMET, 2005; Camberato et al., 2006; Rashid et al., 2006; Gavrilescu, 2008; Monte et al., 2009; Mäkelä et al., 2012; Pervaiz and Sain, 2015). For instance, PPMS applied as a soil amendment must follow regulatory standards in order to avoid soil and watershed contaminations (Camberato et al., 2006). In Canada, heavy metal contents of PPMS 


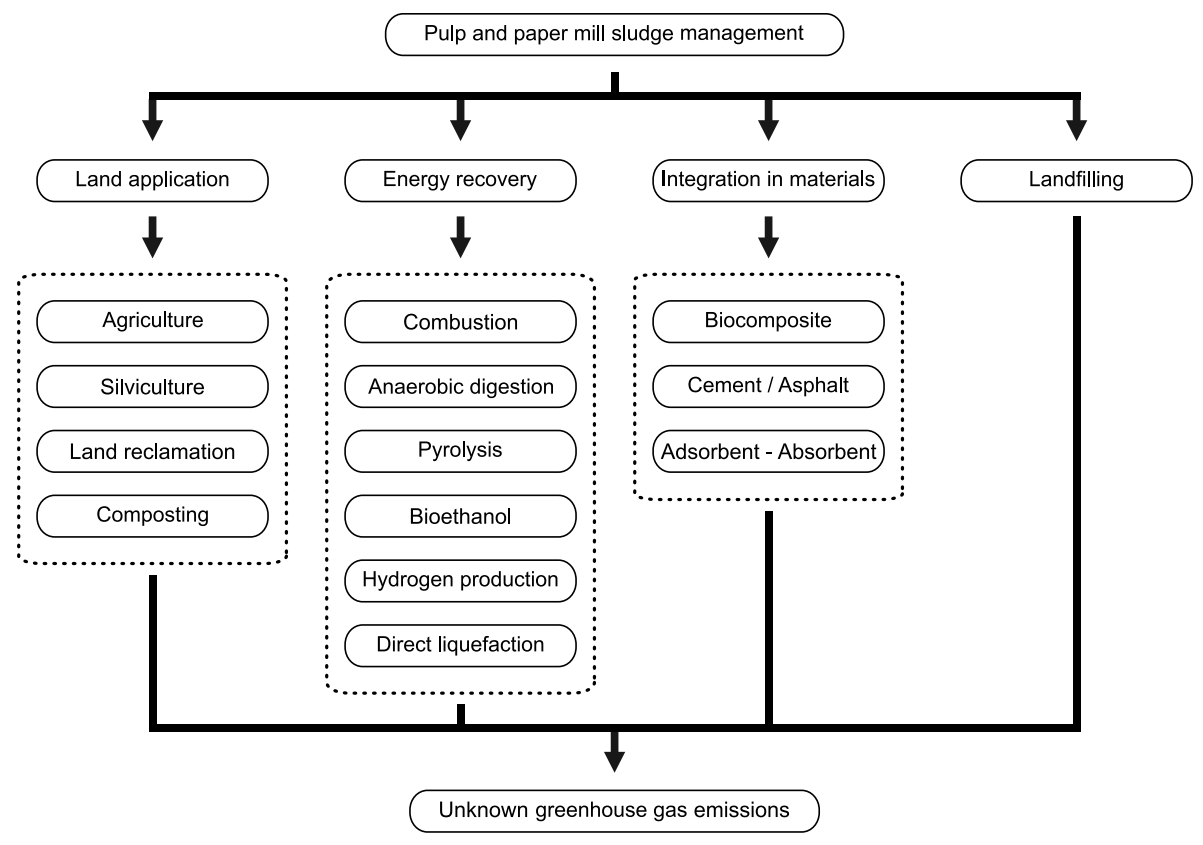

Fig. 1. Overview of the actual and emerging management practices for pulp and paper mill sludge regarding the unknown effects on the greenhouse gas emissions.

are usually less than municipal biosolids and as they are within the regulatory limits of all provinces they can be used as soil amendments (Camberato et al., 1997, 2006). It is also important to take into account heavy metal contents of PPMS when using it in energy recovery practices (CANMET, 2005; Tsupari et al., 2007; Gavrilescu, 2008). Emissions and ashes from the PPMS combustion in biomass boilers are treated by modern technologies and respect the regulatory standards in Canada (CANMET, 2005).

The following sections will describe the actual and possible future practices for PPMS management. The practices presented in this paper can be economically and environmentally attractive options and/or alternatives to the actual disposal by landfilling, which is being reduced or banned in some jurisdictions (Council of the European Communities, 1991; US EPA, 1994; Ljunggren Söderman, 2003; EC-BiPRO, 2007; Fytili and Zabaniotou, 2008; Monte et al., 2009; MfE, 2010; MDDEP, 2011; Gouvernement du Québec, 2012). These PPMS management practices are summarized in Fig. 1 which underlines one crucial and important question regarding climate change: what will be the impact of these PPMS management practices on GHG emissions? Several countries make some or great efforts to apply GHG emission reduction plans. These plans need to consider GHG emission contributions from the current PPMS management practices in order to compare the former emissions to those of future management practices as estimated in life cycle analyses. Thus, one of the future challenges will be to integrate PPMS management practices in scenarios with lower GHG emissions than the current scenarios without increasing the overall management costs for pulp and paper mills. Life cycle analyses will become a key tool to assess the changes in PPMS management practices and their impact on GHGs but at the moment data are missing to feed the models.

It is important to define which GHGs are targeted in current and future scenarios of PPMS management practices. In this review, GHG emissions refer to carbon dioxide $\left(\mathrm{CO}_{2}\right.$; Global warming potential for 100 years $\left.-\mathrm{GWP}_{100}=1\right)$, nitrous oxide $\left(\mathrm{N}_{2} \mathrm{O}\right.$; $\left.\mathrm{GWP}_{100}=265\right)$ and methane $\left(\mathrm{CH}_{4} ; \mathrm{GWP}_{100}=28\right)$, three important GHGs included in usual GHG inventories (IPCC, 2006, 2013). $\mathrm{CO}_{2}$ emissions from biogenic sources (e.g., biomass) are excluded from GHG inventories, as far as they are included in the carbon stock changes if there is a change of the land use category (IPCC, 2006).
Thus here, GHG inventories refer to $\mathrm{CO}_{2}$ emissions from nonbiogenic sources (e.g., fossil fuel), and $\mathrm{N}_{2} \mathrm{O}$ and $\mathrm{CH}_{4}$ from both biogenic and non-biogenic sources (IPCC, 2006).

\section{Land application of PPMS}

Land application of PPMS is a common alternative option to landfilling. PPMS is used as an organic soil amendment in agriculture, silviculture and land reclamation, and can be composted prior to land application (Table 2). Once applied onto the land, PPMS nutrients (Table 1) are recycled from the biomass to the soil.

\subsection{Land application of PPMS in agriculture}

A complete literature review has been published on the benefits of using PPMS as an organic soil amendment in agriculture (Camberato et al., 2006), but few studies reported on the impact of this practice on GHG emissions (Baggs et al., 2002; Chantigny et al., 2013). Land application of PPMS in agriculture is performed at the beginning and/or the end of the growing season by spreading and incorporating the organic matter into the soil. Benefits of applying PPMS are well known in agriculture as it increases soil quality and consequently crop yield (Tables 2 and 3). PPMS land application improves soil fertility by increasing organic matter content (i.e., carbon), nutrient content (e.g., nitrogen, phosphorus and potassium), $\mathrm{pH}$, aggregates and water holding and cation exchange capacities (Table 3; Camberato et al., 2006). PPMS can also be used as a liming agent (Camberato et al., 2006; Rato Nunes et al., 2008), which can substitute commercial lime.

Land application of PPMS increases soil microbial activity and biomass as well as the abundance of invertebrates (Table 2). Chantigny et al. (2000) reported that applied de-inking PPMS stimulated microbial growth and activity while enzyme activity leveled off at a rate of $50 \mathrm{Mgdry} \mathrm{ha}^{-1}$ resulting from an excessive carbon input. Similarly, a laboratory study revealed that application of secondary PPMS from Kraft mill at rates ranging between 10 and $50 \mathrm{Mg}$ wet ha $^{-1}$ (PPMS collected from the landfill site after one year disposal) increased microbial and enzyme activities (Gallardo et al., 2010). However, the same type of PPMS applied in a field experiment at rates of 10,20 and $30 \mathrm{Mg}$ wet ha $^{-1}$ did not modify 
Table 2

Summary of the beneficial uses of pulp and paper mill sludge (PPMS) for land application in agriculture, silviculture, land reclamation and composting.

\begin{tabular}{|c|c|c|}
\hline Type of PPMS & Beneficial uses & References \\
\hline \multicolumn{3}{|l|}{ Agriculture } \\
\hline \multirow[t]{2}{*}{-All types } & -Reviews on the beneficial uses of PPMS as a soil amendment and a & Cabral et al. (1998) \\
\hline & plant nutrient source & Camberato et al. (2006) \\
\hline \multirow[t]{20}{*}{-All types } & -Effects on yields of various crops (corn, barley, wheat, soybean, & Dolar et al. (1972) \\
\hline & cranberry dry bean, oat, sugarcane, turfgrass, tall wheat grass, meadow & Field et al. (1996) \\
\hline & foxtail, hard fescue, galega, black medic, yellow sweet clover, and & Norrie and Gosselin (1996) \\
\hline & strawberry) and soil properties of fine and coarse-textured soils & Trépanier et al. (1996) \\
\hline & & Fierro et al. (1997) \\
\hline & & Aitken et al. (1998) \\
\hline & & Simard et al. (1998) \\
\hline & & Zibilske et al. (2000) \\
\hline & & Legendre et al. (2004) \\
\hline & & Curnoe et al. (2006) \\
\hline & & N'Dayegamiye $(2006,2009)$ \\
\hline & & Price and Voroney (2007) \\
\hline & & Rato Nunes et al. (2008) \\
\hline & & Tripathy et al. (2008) \\
\hline & & Fan et al. (2010) \\
\hline & & Gagnon et al. (2010) \\
\hline & & Amini et al. (2012) \\
\hline & & Gagnon and Ziadi (2012) \\
\hline & & Gagnon et al. (2012) \\
\hline & & Ziadi et al. (2013) \\
\hline -Primary & -Definition of a PPMS application index using GIS tools & Ribeiro et al. (2010) \\
\hline \multicolumn{3}{|c|}{ 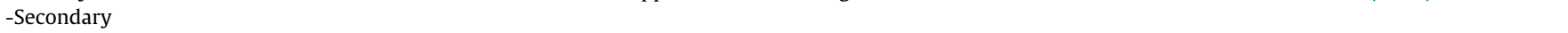 } \\
\hline -Secondary (extracted from & -Effect on soil properties (volcanic soils), microbial community and & Gallardo et al. (2010) \\
\hline a landfill site after 1 year) & yields (crop: Lolium perenne L.) & Gallardo et al. (2012) \\
\hline \multirow[t]{6}{*}{-De-inking } & -Dynamics of PPMS decomposition and its role on soil microflora and & Chantigny et al. (1999) \\
\hline & structure in fine-textured soils: & Chantigny et al. (2000) \\
\hline & - Aggregate formation & \\
\hline & - Microbial biomass & \\
\hline & • Enzyme activity & \\
\hline & - Active carbon pool & \\
\hline \multirow[t]{2}{*}{-De-inking } & -Effects on invertebrates (various earthworm species) in fine and & Piearce and Boone (1998) \\
\hline & coarse-textured soils & Price and Voroney (2008) \\
\hline -De-inking & $\begin{array}{l}\text {-Effect on dinitrogen fixation in forage legumes (alfalfa, birdsfoot } \\
\text { trefoil, red clover and sweetclover) }\end{array}$ & Allahdadi et al. (2004) \\
\hline \multicolumn{3}{|l|}{ Silviculture } \\
\hline \multirow[t]{9}{*}{-All types } & -Effects on forest stand growth (various stands: radiata pine, red pine, & 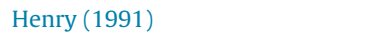 \\
\hline & lodgepole pine, white spruce, Douglas-fir, maple, alder, aspen and & Kraske and Fernandez (1993) \\
\hline & shrub willow) and soil properties & Henry et al. (1994) \\
\hline & & Cabral et al. (1998) \\
\hline & & Macyk (1999) \\
\hline & & Jackson et al. (2000) \\
\hline & & Feldkirchner et al. (2003) \\
\hline & & Filiatrault et al. (2006) \\
\hline & & Quaye et al. (2011) \\
\hline -Primary & -PPMS used as herbicide on clear-cut areas & Lo et al. (1996) \\
\hline \multirow{2}{*}{-Mixed } & -Effect of the toxic chlorinated organic compound & Vera and Servello (1994) \\
\hline & $\begin{array}{l}\text { 2,3,7,8-tetrachlorodibenzo-p-dioxin on breeding birds and small } \\
\text { mammals }\end{array}$ & \\
\hline -De-inking & $\begin{array}{l}\text {-Development of a forest soil amendment combining PPMS with } \\
\text { residues from steel and pulp and paper industries }\end{array}$ & Mäkelä et al. (2010) \\
\hline \multicolumn{3}{|l|}{ Land reclamation } \\
\hline \multirow[t]{2}{*}{-All types } & -Reviews on the beneficial uses of PPMS as an organic amendment for & Camberato et al. (2006) \\
\hline & the restoration and rehabilitation of reclaimed sites & Larney and Angers (2012) \\
\hline \multirow[t]{3}{*}{-All types } & -Effects on the vegetation (species: bermuda grass, tall wheatgrass), & Feagley et al. (1994) \\
\hline & soil properties and runoff water quality of reclaimed sites & Fierro et al. (1999) \\
\hline & & Shipitalo and Bonta (2008) \\
\hline $\begin{array}{l}\text {-De-inking (byproduct of } \\
\text { paper recycling) }\end{array}$ & $\begin{array}{l}\text {-Effects on invertebrates (various earthworm species) in the } \\
\text { restoration of a former landfill site }\end{array}$ & Piearce et al. (2003) \\
\hline \multicolumn{3}{|l|}{ Composting } \\
\hline \multirow[t]{2}{*}{-All types } & -Reviews presenting some beneficial uses of composted PPMS & Camberato et al. (2006) \\
\hline & & Hubbe et al. (2010) \\
\hline -All types & -Vermicomposting of PPMS alone or combined with municipal & Elvira et al. (1998) \\
\hline & biosolids or dairy sludge & Quintern (2014) \\
\hline -Secondary & -Effects of co-composting with other residues (i.e., poultry manure, & Baziramakenga and Simard (2001) \\
\hline -De-inking & chicken broiler floor litter, hog manure) on: & Charest and Beauchamp (2002) \\
\hline & -Compost and soil properties & Lalande et al. (2003) \\
\hline & -Crops (snap bean, potato and wheat) & Charest et al. (2004) \\
\hline & & Gea et al. (2005) \\
\hline
\end{tabular}


Table 3

Summarized results from selected studies on the effects of land application of pulp and paper mill sludge (PPMS) in agriculture on soil and crop properties.

\begin{tabular}{|c|c|c|c|c|c|c|}
\hline Type of PPMS & C:N & Application rate & $\begin{array}{l}\text { Soil texture and } \\
\text { location }\end{array}$ & Crop & Main PPMS effects & Reference \\
\hline -Secondary & $-11: 1$ & $\begin{array}{l}\text {-Control, } 38,88 \text { and } \\
120 \mathrm{Mg} \mathrm{ha}^{-1} \text {, equivalent to } \\
0-40 \mathrm{~g} \mathrm{~kg}^{-1} \\
-188 \text { days, greenhouse } \\
\text { study }\end{array}$ & $\begin{array}{l}\text {-Cambic Arenosol } \\
\text { (cmAR) } \\
\text {-Sandy loam Cromic } \\
\text { Cambisol (crCM) } \\
\text {-Portugal }\end{array}$ & -Wheat & $\begin{array}{l}\text {-Soil: } \\
\text { Increase of pH, organic C and } \mathrm{N} \text { contents, available } \mathrm{P} \\
\text { and exchangeable } \mathrm{K} \\
\text {-Crop: } \\
\text { Rate of } 38 \mathrm{Mg} \mathrm{ha}^{-1} \text { : increase of grain yield in crCM } \\
\text { soil } \\
\text { Rate of } 120 \mathrm{Mg} \mathrm{ha}^{-1}: 32 \% \text { and } 36 \% \text { decrease of grain } \\
\text { yield in } \mathrm{cmAR} \text { and crCM soils, respectively } \\
\text { Increase of wheat } \mathrm{N} \text { content } \\
\text { Decrease of wheat } \mathrm{Zn}, \mathrm{Mn} \text { and Cu contents }\end{array}$ & $\begin{array}{l}\text { Rato Nunes et al. } \\
\text { (2008) }\end{array}$ \\
\hline -Secondary & $-16: 1-27: 1$ & $\begin{array}{l}\text {-Control, } 15 \text { and } \\
25 \text { Mg dry ha }^{-1} \\
\text {-5-yr field study }\end{array}$ & $\begin{array}{l}\text {-Sandy loam } \\
\text {-Ontario, Canada }\end{array}$ & -Corn & $\begin{array}{l}\text {-Soil: } \\
\text { Increase of organic matter but little evidence for } \\
\text { long-term accumulation } \\
\text {-Crop: } \\
\text { Rate of } 15 \mathrm{Mg} \mathrm{dry} \mathrm{ha} \mathrm{ha}^{-1}: 123 \% \text { increase of grain yield } \\
\text { Rate of } 25 \mathrm{Mg} \text { dry ha } \mathrm{h}^{-1}: 152 \% \text { increase of grain yield } \\
\text { Increase of plant total } \mathrm{N} \text { content }\end{array}$ & Curnoe et al. (2006) \\
\hline $\begin{array}{l}\text {-Mixed (from bleached } \\
\text { Kraft pulp) with 3\% } \\
\text { addition of municipal } \\
\text { biosolids }\end{array}$ & $-13: 1-16: 1$ & $\begin{array}{l}\text {-Control, } 30,60 \text { and } \\
120 \mathrm{Mg} \text { wet ha }^{-1} \\
-3 \text {-yr field study }\end{array}$ & $\begin{array}{l}\text {-Loamy sand } \\
\text {-Ontario, Canada }\end{array}$ & -Silage corn & $\begin{array}{l}\text {-Soil: } \\
\text { Increase of } \mathrm{NO}_{3}-\mathrm{N} \text { content and P saturation index } \\
\text { Increased (or at least maintained) organic matter } \\
\mathrm{Cd} \text { and } \mathrm{Zn} \text { accumulations } \\
\mathrm{Recommendation} \mathrm{to} \mathrm{not} \mathrm{exceed} \mathrm{a} \mathrm{rate} \mathrm{of} 60 \mathrm{Mg} \text { wet } \mathrm{ha}^{-1} \text { to limit contamination by } \mathrm{NO}_{3}^{-}, \mathrm{P} \text { and metals } \\
\text {-Crop: } \\
\text { Rate of } 120 \mathrm{Mg} \text { wet ha }{ }^{-1}: 50 \% \text { increase of corn yield } \\
\text { in the } 3 \mathrm{rd} \text { year } \\
\text { Rates of } 30 \mathrm{Mg} \text { wet ha }^{-1} \text { with reduced mineral } \mathrm{N} \text { and } \\
60 \mathrm{Mg} \text { wet ha }{ }^{-1} \text { resulted in yields comparable with } \\
\text { those obtained with complete mineral } \mathrm{N} \text { fertilization } \\
\mathrm{Cd} \text { and } \mathrm{Zn} \text { accumulations in plant tissues }\end{array}$ & Gagnon et al. (2010) \\
\hline $\begin{array}{l}\text {-Mixed (60\% } \\
\text { primary-40\% } \\
\text { secondary) }\end{array}$ & $-14: 1$ & $\begin{array}{l}\text {-Control, } 18,36 \text { and } \\
54 \mathrm{Mg} \text { wet ha }^{-1} \\
-6 \text {-yr field study }\end{array}$ & $\begin{array}{l}\text {-Sandy loam } \\
\text {-Clay loam } \\
\text {-Quebec, Canada }\end{array}$ & $\begin{array}{l}\text {-Grain corn } \\
\text {-Silage corn } \\
\text {-Barley } \\
\text {-Soybean }\end{array}$ & $\begin{array}{l}\text {-Soil: } \\
\text { Sandy loam: increase of } \mathrm{N} \text { mineralization, microbial } \\
\text { respiration rates and C content } \\
\text { Clay loam: increase of the macroaggregate sizes, } \\
\text { mean weight diameter of waterstable aggregates, } \\
\text { microbial respiration rates and C content } \\
\text {-Crop: } \\
\text { Sandy loam: increase of silage and grain corn yields } \\
\text { Clay loam: increase of grain corn yield }\end{array}$ & $\begin{array}{l}\text { N'Dayegamiye } \\
\text { (2009) }\end{array}$ \\
\hline $\begin{array}{l}\text {-Mixed (60\% } \\
\text { primary-40\% } \\
\text { secondary) }\end{array}$ & $-19: 1-24: 1$ & $\begin{array}{l}\text {-Control, } \\
20-60 \text { Mg wet ha }{ }^{-1} \\
-3 \text {-yr field study }\end{array}$ & $\begin{array}{l}\text {-Silt loam } \\
\text {-Quebec, Canada }\end{array}$ & -Corn & $\begin{array}{l}\text {-Soil: } \\
\text { Rate of } 40 \mathrm{Mg} \text { wet ha }{ }^{-1}: 22 \% \text { and } 16 \% \text { increases of C } \\
\text { and } \mathrm{N} \text { contents, respectively } \\
\text { Rate of } 60 \mathrm{Mg} \text { wet ha } \mathrm{C}^{-1}: 26 \% \text { and } 16 \% \text { increases of C } \\
\text { and } \mathrm{N} \text { contents, respectively } \\
\text {-Crop: } \\
35-65 \% \text { increase of grain yield compared to the } \\
\text { control }\end{array}$ & $\begin{array}{l}\text { N'Dayegamiye } \\
\text { (2006) }\end{array}$ \\
\hline
\end{tabular}


Table 3 (Continued)

\begin{tabular}{|c|c|c|c|c|c|c|}
\hline Type of PPMS & $\mathrm{C}: \mathrm{N}$ & Application rate & $\begin{array}{l}\text { Soil texture and } \\
\text { location }\end{array}$ & Crop & Main PPMS effects & Reference \\
\hline$-N D$ & $-22: 1-25: 1$ & $\begin{array}{l}\text {-Control, } 30,60 \text { and } \\
90 \mathrm{Mg}^{-} \text {et ha } \\
\text {-1 } \\
-6 \text {-yr field study }\end{array}$ & $\begin{array}{l}\text {-Loam } \\
\text {-Quebec, Canada }\end{array}$ & -Grain corn & $\begin{array}{l}\text {-Soil: } \\
\text { Increase of organic P availability } \\
\text { Promoted transformation of residual P to more labile } \\
\mathrm{P} \text { forms } \\
\text { Increase of total C and } \mathrm{N} \text { contents } \\
\text { Supply of Ca }\end{array}$ & Fan et al. (2010) \\
\hline -Mixed & $-22: 1-26: 1$ & $\begin{array}{l}\text {-Control, } 30,60 \text { and } \\
90 \text { Mg wet ha }{ }^{-1} \\
\text {-9-yr field study: } \\
\text { Years 1-3: mixed PPMS } \\
\text { from thermo-mechanical } \\
\text { pulp } \\
\text { Years 4-9: mixed PPMS } \\
\text { from bleached Kraft pulp }\end{array}$ & $\begin{array}{l}\text {-Loam } \\
\text {-Quebec, Canada }\end{array}$ & $\begin{array}{l}\text {-Grain corn } \\
\text {-Cranberry dry bean } \\
\text {-Natto soybean }\end{array}$ & $\begin{array}{l}\text {-Soil: } \\
\text { Increase of organic matter and all major nutrients, } \\
\text { except } \mathrm{K} \text { and } \mathrm{Mg} \\
\text {-Crop: } \\
\text { Rate of } 90 \mathrm{Mg} \text { wet ha }{ }^{-1}: 19 \% \text { increase of grain corn } \\
\text { yield; } 26 \% \text { increase of cranberry dry bean yield }\end{array}$ & $\begin{array}{l}\text { Gagnon and Ziadi } \\
\text { (2012) }\end{array}$ \\
\hline $\begin{array}{l}\text {-Two types of mixed } \\
\text { PPMS } \\
\text {-De-inking }\end{array}$ & $\begin{array}{l}\text {-Mixed: 31:1, 14:1 } \\
\text {-De-inking: 65:1 }\end{array}$ & $\begin{array}{l}\text {-Control, } 30 \text { and } \\
60 \mathrm{Mg} \mathrm{wet} \mathrm{ha}^{-1} \text { for mixed } \\
\text { and de-inking PPMS } \\
\text {-Greenhouse study }\end{array}$ & $\begin{array}{l}\text {-Combination of sandy } \\
\text { soils: Gleyed } \\
\text { Humo-Ferric Podzol } \\
\text { and Orthic } \\
\text { Humo-Ferric Podzol } \\
\text {-Quebec, Canada }\end{array}$ & $\begin{array}{l}\text {-Mixed: } \\
\text { Dry bean with PPMS } \\
\text { at C:N } 31 \\
\text { Barley with PPMS at } \\
\text { C:N } 14 \\
\text {-De-inking } \\
\text { Soybean }\end{array}$ & 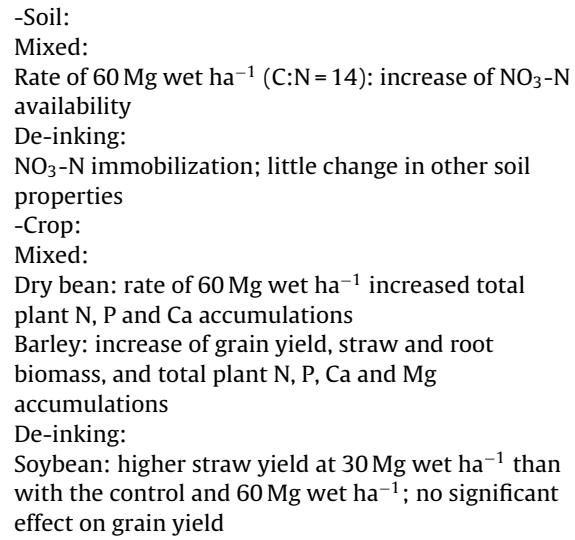 & Ziadi et al. (2013) \\
\hline $\begin{array}{l}\text {-Mixed } \\
\text { (primary-secondary) } \\
\text {-De-inking }\end{array}$ & $\begin{array}{l}\text {-Mixed: 13:1-21:1 } \\
\text {-De-inking: } \\
\text { 50:1-71:1 }\end{array}$ & $\begin{array}{l}\text {-Mixed: } \\
\text { Control, } \\
4.24-6.90 \mathrm{Mg} \mathrm{dry} \mathrm{ha}^{-1} \\
\text {-De-inking: } \\
\text { Control, } \\
\text { 25.9-38.1 Mg dry ha-1 } \\
\text {-3-yr field study }\end{array}$ & $\begin{array}{l}\text {-Clay } \\
\text {-Quebec, Canada }\end{array}$ & -Silage corn & $\begin{array}{l}\text {-Soil: } \\
\text { De-inking PPMS increased Zn availability } \\
\text {-Crop: } \\
\text { Mixed PPMS (2-3-yr average): } \\
\text { Yield: } 34 \% \text { higher than control } \\
\text { N-use efficiency: } 16 \mathrm{~kg} \text { dry matter } \mathrm{kg}^{-1} \mathrm{~N} \text { applied } \\
\mathrm{N} \text {-accumulation: } 30 \% \text { higher than control } \\
\text { P-accumulation: } 13 \% \text { higher than control } \\
\text { De-inking PPMS ( } 2 \text { - } 3 \text {-yr average): } \\
\text { Yield: } 43 \% \text { lower than control } \\
\text { N-use efficiency: }-20 \mathrm{~kg} \text { dry matter } \mathrm{kg}^{-1} \mathrm{~N} \text { applied } \\
\text { N-accumulation: } 12 \% \text { lower than control } \\
\text { P-accumulation: } 34 \% \text { lower than control }\end{array}$ & Gagnon et al. (2012) \\
\hline -De-inking & $-219: 1$ & $\begin{array}{l}\text {-Control, } 50 \text { and } \\
100 \text { Mg dry ha }^{-1} \\
\text {-3-yr field study }\end{array}$ & $\begin{array}{l}\text {-Clay loam } \\
\text {-Silty clay loam } \\
\text {-Quebec, Canada }\end{array}$ & $\begin{array}{l}\text {-Alfalfa } \\
\text {-Bromegrass } \\
\text {-Sweet corn }\end{array}$ & $\begin{array}{l}\text {-Soil: } \\
\text { Increase of C content after } 2 \text { years } \\
\text { Residual C attributed to de-inking PPMS: } \\
\text { Particulate fraction: remained constant at } 70-90 \% \\
\text { Light fraction: decrease from }>95 \% \text { to }<50 \% \\
\text { Increase of the proportion of soil water-stable } \\
\text { aggregates ( }>1 \mathrm{~mm} \text { ) from } 2 \text { to } 6 \text { times. Effects were } \\
\text { still detectable after } 3 \text { years. }\end{array}$ & $\begin{array}{l}\text { Chantigny et al. } \\
\text { (1999) }\end{array}$ \\
\hline
\end{tabular}


Table 4

Summarized results from selected studies on the effects of land application of pulp and paper mill sludge (PPMS) in silviculture on soil and stand properties.

\begin{tabular}{|c|c|c|c|c|}
\hline Type of PPMS & Application rate & Stand description & Main PPMS effects & Reference \\
\hline -Primary (composted) & $\begin{array}{l}\text {-Control, 20, } 40 \text { and } \\
60{\mathrm{Mg} \text { dry } \mathrm{ha}^{-1}}^{-1-\mathrm{yr} \text { field study }}\end{array}$ & $\begin{array}{l}\text {-Radiata pine (Pinus } \\
\text { radiata) }\end{array}$ & $\begin{array}{l}\text {-Soil: } \\
\text { - N release from composted PPMS was } \\
\text { mostly absorbed by plant roots within } \\
\text { the } 20 \mathrm{~cm} \text { soil depth; no significant } \\
\text { movement below this depth was } \\
\text { measured } \\
\text {-Stand: } \\
\text { - Increase of stem diameter by } 40-66 \% \text {, } \\
\text { with the highest application rate } \\
\text { resulting in higher growth } \\
\text { - Increase of } 17-37 \% \text { of the foliar N } \\
\text { concentration } \\
\text { - Decrease of water stress }\end{array}$ & Jackson et al. (2000) \\
\hline -Mixed & $\begin{array}{l}\text {-Control, } 40 \mathrm{Mg} \text { dry ha }^{-1} \\
-2-\mathrm{yr} \text { field study }\end{array}$ & -Red pine (Pinus resinosa) & $\begin{array}{l}\text {-Soil: } \\
\text { - Increase of forest floor pH by } \\
\text { approximately one unit } \\
\text { - Increase of exchangeable } \mathrm{Ca}^{2+} \text { and } \\
\mathrm{Mg}^{2+} \text { by } 100 \% \text { and } 60 \% \text {, respectively } \\
\text { - Increase of cation-exchange capacity } \\
\text { and base saturation by } 60 \% \text { and } 34 \% \text {, } \\
\text { respectively } \\
\text { - One year after mixed } \mathrm{PPMS}^{2-} \\
\text { application, only } \mathrm{N}^{+} \text {and } \mathrm{SO}_{4}^{2-} \\
\text { concentrations among base cations } \\
\text { remained five and three times higher } \\
\text { than the control } \\
\text { - When compared to the harvesting } \\
\text { operations, PPMS had much less impact } \\
\text { on soil biogeochemical processes }\end{array}$ & $\begin{array}{l}\text { Kraske and Fernandez } \\
\text { (1993) }\end{array}$ \\
\hline -Mixed & $\begin{array}{l}\text {-Rates in the } 1 \text { st year: } \\
\text { Control, } 16 \text { and } \\
33 \mathrm{Mg} \text { wet ha }^{-1} \\
\text {-Rates in the } 2 \text { nd year: } \\
\text { Control, } 32 \text { and } \\
64 \mathrm{Mg} \text { wet ha } \\
\text {-2-yr field study }\end{array}$ & $\begin{array}{l}\text {-Maple stands dominated } \\
\text { by sugar maple (Acer } \\
\text { saccharum) } \\
\text {-Aspen stands dominated } \\
\text { by quaking aspen (Populus } \\
\text { tremuloides) }\end{array}$ & $\begin{array}{l}\text {-Soil: } \\
\text { - Maple stands: } \\
\text { - In the soil layer } 0-10 \mathrm{~cm} \text { : increase of } \\
\text { soil pH by } 10 \% \text { and Ca concentration } \\
\text { with } 64 \mathrm{Mg} \text { wet ha }{ }^{-1} \\
\text { - Increase of understory Fe and } \mathrm{Mg} \\
\text { concentrations with } 64 \mathrm{Mg} \text { wet ha }{ }^{-1} \\
\text { - Aspen stands: } \\
\text { - Increase of soil pH }(0-10 \mathrm{~cm} \text { layer) by } \\
15 \% \text { with } 64 \mathrm{Mg} \text { wet ha }{ }^{-1} \\
\text { - For both stands: } \\
\text { - Increase of understory } \mathrm{N}^{-} \text {and } \mathrm{P} \\
\text { concentrations with } 64 \mathrm{Mg}^{-1} \text { wet ha } \\
\text {-Stand: } \\
\text { - Increase of foliar } \mathrm{N} \text { concentration for } \\
\text { both stands with } 64 \mathrm{Mg} \text { wet ha }^{-1} \\
\text { - No PPMS effects on stand growths }\end{array}$ & $\begin{array}{l}\text { Feldkirchner et al. } \\
\text { (2003) }\end{array}$ \\
\hline -De-inking & $\begin{array}{l}\text {-Control, } 73 \mathrm{Mg} \text { wet ha } \\
\text {-3-yr field study on two sites }\end{array}$ & $\begin{array}{l}\text {-Shrub willow (Salix } \\
\text { dasyclados) }\end{array}$ & $\begin{array}{l}\text { No PPMS effects on soil and stand } \\
\text { properties }\end{array}$ & Quaye et al. (2011) \\
\hline
\end{tabular}

greatly the soil microbial community of fungi and bacteria (Gallardo et al., 2012). Applied de-inking PPMS also increases the abundance of earthworms, thus improving soil properties (Piearce and Boone, 1998; Price and Voroney, 2008).

Several studies have reported an increased crop yield following land application of PPMS (Tables 2 and 3). One of the conclusions from these studies was that repeated applications of mixed PPMS with reduced nitrogen fertilizer rate was a sustainable agricultural practice with the potential to maintain crop quality and yield and improve soil properties (N'Dayegamiye, 2006, 2009; Gagnon and Ziadi, 2012). It is important to consider the effect of the PPMS C: $\mathrm{N}$ ratio on soil nitrogen immobilization which in turn affects crop yield (Camberato et al., 2006). Problems with soil nitrogen immobilization can be avoided by the addition of mineral nitrogen fertilizer combined with applied PPMS or use of legumes (Camberato et al., 2006). Optimum nitrogen rates will depend on the crop, soil and PPMS characteristics (Camberato et al., 2006). Land application of PPMS in agriculture is generally well accepted and common in areas where pulp and paper mills are localized but some factors can limit this practice (Camberato et al., 2006; Rashid et al., 2006). For instance, heavy metal content is one of the major public concerns although it is usually less than municipal biosolids and below the regulatory limits (Camberato et al., 2006). In some cases, other considerations such as site and soil characteristics, distance from surface water and wells, depth to groundwater, potential erosion and runoff, and proximity to floodplains or wetlands can be obstacles to land application (Camberato et al., 2006). However, PPMS land application is usually well monitored for the dosages and times of application and must respect the state rules in order to avoid soil and water contamination (Camberato et al., 2006; Rashid et al., 2006).

\subsection{Land application of PPMS in silviculture}

Land application of PPMS is practiced in silviculture to improve soil properties after harvesting and promote stand regeneration (Tables 2 and 4). However, this practice seems to be less common than the application on agricultural lands according to the fewer studies on the topic (Tables 2 and 4). As it does onto agricultural land, PPMS applied as an organic amendment in managed forests affect soil properties by increasing nitrogen content as well as cation exchange capacity, base saturation and $\mathrm{pH}$ (Table 4). PPMS 
application has also positive effects on managed stand growths and foliar nutrient status (Table 4; Macyk, 1999). Macyk (1999) reported that PPMS application (from mechanical pulp mill) increased white spruce (Picea glauca) and lodgepole pine (Pinus contorta var. latifolia) seedling height and diameter by up to 2.5 times compared with the control. Application of composted primary PPMS could also be an acceptable recycling alternative as it was found to improve plantation productivity (Jackson et al., 2000). However, contrasting results were also reported on the effect of mixed and de-inking PPMS applications as it did not benefit maple, aspen and willow stand growths and affect soil properties (Feldkirchner et al., 2003; Quaye et al., 2011).

Primary PPMS can also act as herbicide on clear-cut areas targeted for stand regenerations (Table 2). Lo et al. (1996) applied primary PPMS as a substitute for herbicides, one year prior to the plantation of hybrid poplar cuttings. Weed growth was decreased by $75-90 \%$ and the effect lasted during the second year without additional application.

The use of mixed PPMS on forest soil for stand regeneration could have adverse effects on wildlife as they contain 2,3,7,8-tetrachlorodibenzo-p-dioxin (TCDD), a chlorinated organic compound, known to be toxic and/or sublethal on adult animals and bird embryos (Table 2). Nevertheless, Vera and Servello (1994) reported that mixed PPMS application at a rate of $45 \mathrm{Mg}$ dry ha $^{-1}$ on regenerating spruce-fir (Picea spp. - Abies balsamea) forest stands did not affect breeding birds or small mammal communities in the first and second years following application. However, species known to be affected by TCDD were in negligible abundance in the studied forests, which most likely explained the absence of noticeable adverse effects (Vera and Servello, 1994). TCDD levels in PPMS used in silviculture should therefore remain a cause for concern as more research is needed on their impacts on the surrounding fauna.

PPMS can be combined with various industrial residues to be used as forest soil amendments (Table 2). Mäkelä et al. (2010) developed such an amendment by incorporating de-inking PPMS as a reactive aggregate with other residues from Finnish steel and pulp and paper industries. The resulting forest soil amendment had properties comparable to commercial ground limestone products (Mäkelä et al., 2010). The total concentration of chrome exceeded the Finnish statutory limit value for forest soil amendment only under severe leaching tests (Mäkelä et al., 2010). Thus, there could be a potential to integrate PPMS with residues from different industries to produce forest soil amendments as long as it does not counteract climate change mitigation actions.

\subsection{Land application of PPMS for land reclamation}

PPMS is a valuable soil organic amendment for land reclamation (Table 2). Examples of degraded soils are eroded agriculture sites, oil and gas well sites, mine tailing sites, abandoned quarries and temporary roads on managed forest sites (Larney and Angers, 2012). Such types of soils lack organic matter, which can be remediated by the high organic content of PPMS (Shipitalo and Bonta, 2008; Larney and Angers, 2012). Sludge application on degraded soils can also increase its biota by sustaining earthworm communities (Piearce et al., 2003). Moreover, soil aggregate formation favored by PPMS application can become hotspots for microbial and faunal activity (Larney and Angers, 2012). Nitrogen content immediately available for plant growth (i.e., mineralized nitrogen) is also increased, as long as a high C: $\mathrm{N}$ ratio does not favor nitrogen immobilization (Larney and Angers, 2012; Thangarajan et al., 2013), which could seriously hinder a land reclamation operation. Cation-exchange capacity of amended degraded soil increases, especially if the PPMS composted prior to their application (Fierro et al., 1999; Larney and Angers, 2012). As measured for agricultural land, PPMS application on degraded soils increases water-holding capacity (Fierro et al., 1999; Larney and Angers, 2012), which can be an important improvement for coarse textured soils. Therefore, the positive effects of PPMS amendments on degraded soil properties can decrease its erosion and favor plant growth on reclaimed land (Shipitalo and Bonta, 2008; Larney and Angers, 2012). Shipitalo and Bonta (2008) showed that mixed PPMS applied to reclaim a surfacecoal mine at rates of 224 and $672 \mathrm{Mgdry} \mathrm{ha}^{-1}$ increased plant growth and decreased soil erosion from $47 \mathrm{Mgha}^{-1}$ to $1 \mathrm{Mg} \mathrm{ha}^{-1}$ compared with the control. Although water runoff was decreased, it contained significant amounts of dissolved organic carbon and increased the chemical oxygen demand (Shipitalo and Bonta, 2008). The authors concluded that PPMS application for surface-mine reclamation could reduce the operational costs as the size of the sediment basins could be smaller than standard practices due to lower water runoff (Shipitalo and Bonta, 2008).

\subsection{PPMS composting prior to land application}

Composting of PPMS prior to land application enhances its overall quality as a soil amendment (Table 2; Joo et al., 2015). Composting is a biological process that converts lignocellulosic residues, such as PPMS, into a stabilized and non-hazardous material, rich in humic-like substances devoid of pathogens (Hubbe et al., 2010). Composting of primary and de-inking PPMS with other types of nitrogen-rich wastes decreases C: $\mathrm{N}$ ratio, prevents soil nitrogen immobilization and renders the resulting amendment suitable for plant growth (Camberato et al., 2006; Hubbe et al., 2010). Some studies reported on the co-composting of PPMS with municipal biosolids, fertilizers, animal manures and chicken broiler floor litter (Table 2). De-inking PPMS was composted with poultry manure and chicken broiler floor litter during 24 weeks at three initial nitrogen contents of $0.6 \%, 0.7 \%$ and $0.9 \%$ (Charest and Beauchamp, 2002; Charest et al., 2004). Results showed that the composting process occurred in two steps: the first eight weeks consisted of high cellulose and hemicellulose degradation followed by the decomposition of resistant carbon fractions (Charest et al., 2004). Microbial biomass was at the highest level at the 12th week (Charest et al., 2004). The composting mixture with an initial nitrogen content of $0.6 \%$ yielded the lowest C: $\mathrm{N}$ ratio after 24 weeks and was the best to enhance de-inking PPMS composting by mechanical turning (Charest and Beauchamp, 2002). The initial pH and C:N ratio were found to be the key factors in the composting process however, the 24 -week composting period was not long enough to produce full mature compost (Charest and Beauchamp, 2002). The final product met the requirements of types $\mathrm{AA}$ and $\mathrm{A}$ of the Canadian Compost Standards, except for copper concentration corresponding to type B (Charest and Beauchamp, 2002). Gea et al. (2005) showed the feasibility of composting de-inking and secondary PPMS alone and combined with each other both at the laboratory and pilot scales. No bulking agents were needed when secondary PPMS was cocomposted with de-inking PPMS. Composting of de-inking PPMS did not need any amendments or bulking agents, which would reduce the operating costs if the process was to be applied on a larger scale (Gea et al., 2005). The pilot scale composting experiment showed that $\mathrm{C}: \mathrm{N}$ ratio of the de-inking PPMS was decreased (Gea et al., 2005).

\section{PPMS energy recovery}

PPMS is a type of biomass that allows a variety of energy recovery practices (Table 5), thereby reducing the volume that would be otherwise directed to landfilling. The substrates resulting from the energy recovery of PPMS, such as ashes and biochar (see Section 4.3 below), can also be recycled or reclaimed as soil amendments and/or used in construction materials. Energy recovery can be 
Table 5

Summary of the technologies in which pulp and paper mill sludge (PPMS) is used in energy recovery practices.

\begin{tabular}{|c|c|c|}
\hline Type of PPMS & Technologies & References \\
\hline \multicolumn{3}{|l|}{ Combustion } \\
\hline \multirow[t]{3}{*}{-All types } & -Reviews or reports presenting technologies for PPMS combustion & CANMET (2005) \\
\hline & & Oral et al. (2005) \\
\hline & & Gavrilescu (2008) \\
\hline \multirow[t]{5}{*}{-All types } & -Technologies on drying pretreatments that increase the energy recovery from & Krogerus et al. (1999) \\
\hline & combustion & Frei et al. (2006) \\
\hline & & Navaee-Ardeh et al. (2006) \\
\hline & & Stoica et al. (2009) \\
\hline & & Velis et al. (2009) \\
\hline$-\mathrm{ND}$ & $\begin{array}{l}\text {-Effects of combustion parameters (i.e., water content, feeding rate, secondary } \\
\text { air injection; lab-scale experiment with an internally cycloned circulating } \\
\text { fluidized bed) on carbon conversion ratio, mean carbon conversion time, } \\
\text { pollutant emission ratio and estimated areal mass burning rate }\end{array}$ & Shin et al. (2005) \\
\hline \multicolumn{3}{|l|}{ Anaerobic digestion } \\
\hline -All types & -Review on the anaerobic digestion of PPMS & Meyer and Edwards (2014) \\
\hline -All types & $\begin{array}{l}\text {-Modeling approach evaluating the potential for the substitution of fossil fuel by } \\
\text { biogas from the pulp and paper industry in Sweden }\end{array}$ & Magnusson and Alvfors (2012) \\
\hline \multirow[t]{4}{*}{-All types } & -Modeling approaches estimating GHG emissions & Ashrafi et al. (2013a) \\
\hline & & Ashrafi et al. (2013b) \\
\hline & & O'Connor et al. (2014) \\
\hline & & Ashrafi et al. (2015) \\
\hline \multirow[t]{3}{*}{-Secondary } & -Pretreatments aiming to increase the PPMS digestibility and decrease digester & Elliott and Mahmood (2007) \\
\hline & sizes & Wood et al. (2009) \\
\hline & & Elliott and Mahmood (2012) \\
\hline \multirow[t]{5}{*}{-Secondary } & -MicroSludge process: an alkaline pretreatment ( $900 \mathrm{mg} \mathrm{L}^{-1} \mathrm{NaOH}$ for $1 \mathrm{~h}$ ) to & Rabinowitz and Stephenson (2005) \\
\hline & weaken the cell membrane combined with high pressure homogenizer $(\approx$ & Stephenson et al. (2005) \\
\hline & $83 \mathrm{MPa}$ ) to lyse the cells, resulting in an increased biogas yield & Wood et al. (2009) \\
\hline & & Saha et al. (2011) \\
\hline & & Caulfield (2012) \\
\hline -Secondary & $\begin{array}{l}\text {-Co-digestion with municipal biosolids: the substitution of up to } 50 \% \text { of the } \\
\text { mixture with secondary PPMS did not decrease the } \mathrm{CH}_{4} \text { yield compared with a } \\
\text { full mixture of municipal biosolids }\end{array}$ & Hagelqvist (2013) \\
\hline \multirow[t]{2}{*}{$-\mathrm{ND}$} & -Pretreatments with rumen microorganisms to increase lignocellulose & Gijzen et al. (1988) \\
\hline & degradation & Gijzen et al. (1990) \\
\hline \multicolumn{3}{|l|}{ Pyrolysis } \\
\hline \multirow[t]{7}{*}{-All types } & -Assessments of PPMS: & Méndez et al. (2009b) \\
\hline & - Characteristics for pyrolysis: e.g., $\mathrm{pH}$, electrical conductivity, cation exchange & Strezov and Evans (2009) \\
\hline & capacity, metal content, organic matter and $\mathrm{CaCO}_{3}$ contents & Jiang and Ma (2011) \\
\hline & - Pyrolysis behavior: e.g., maximum weight loss rate and its temperature & Lou et al. (2012) \\
\hline & - Products: gases, bio-oil, biochar & Hossain et al. (2013) \\
\hline & & Ouadi et al. (2013) \\
\hline & & Reckamp et al. (2014) \\
\hline \multicolumn{3}{|l|}{ Bioethanol production } \\
\hline & -Fermentation processes: & \\
\hline & - Separate hydrolysis and fermentation (SHF) & \\
\hline -De-inking & & Marques et al. (2008) \\
\hline -From a bleached Kraft process & & Peng and Chen (2011) \\
\hline \multirow[t]{2}{*}{-From a chemical pulping process } & & Zhu et al. (2011) \\
\hline & - Simultaneous saccharification and fermentation (SSF) & \\
\hline -Primary and de-inking & & Kang et al. (2010) \\
\hline \multirow[t]{2}{*}{-De-inking } & & Lark et al. (1997) \\
\hline & & Marques et al. (2008) \\
\hline \multirow[t]{3}{*}{-From a bleached Kraft process } & & Fan et al. (2003) \\
\hline & & Fan and Lynd (2007a, 2007b) \\
\hline & - Simultaneous saccharification and co-fermentation (SSCF) & \\
\hline -Primary and de-inking & & Kang et al. (2010) \\
\hline -ND & & Zhang and Lynd (2010) \\
\hline & - Consolidated bioprocessing (CBP) & \\
\hline -Primary & & Moreau et al. (2015) \\
\hline Other energy recovery practices & & \\
\hline & -Hydrogen - biological production & \\
\hline -Primary & & Moreau et al. (2015) \\
\hline -Secondary & & Valdez-Vazquez et al. (2005) \\
\hline -ND & & Kádár et al. (2003) \\
\hline & & Kádár et al. (2004) \\
\hline & $\begin{array}{l}\text {-Hydrogen - Production with supercritical water processes: } \\
\text { - Supercritical water gasification (SCWG) }\end{array}$ & \\
\hline -Secondary & & Zhang et al. (2010) \\
\hline & - Supercritical water oxidation (SCWO) & \\
\hline -All types & - Review on the processes for PPMS & Mahmood and Elliott (2006) \\
\hline$-\mathrm{ND}$ & & Crain et al. (2000) \\
\hline & -Direct liquefaction-production of liquid fuel & \\
\hline -Secondary & & $\mathrm{Xu}$ and Lancaster (2008) \\
\hline & & Zhang et al. (2011) \\
\hline
\end{tabular}

ND: PPMS type not determined or specified in the study. 
practiced directly by combustion or indirectly by microbiological and physicochemical processes leading to the production of biogas (through anaerobic digestion) and biofuel (through pyrolysis and bioethanol production). A complete process of PPMS to energy recovery typically includes (1) dewatering and (2) drying to increase the effective thermal heat capacity, (3) thermal conversion or recovery of biofuel or direct use of the aqueous phase in which PPMS is processed for biofuel production (CANMET, 2005). The intensity of the dewatering and drying processes depend on the technology. Combustion requires dewatering and drying prior to burning, dewatering is also needed for anaerobic digestion for biogas production whereas fermentation for ethanol production can use PPMS with low solid content (as low as 20\%), reducing energy consumption for pretreatments (CANMET, 2005; Meyer and Edwards, 2014).

\subsection{Combustion of PPMS}

Some paper mills use PPMS as a renewable source of fuel in biomass boilers and recovery furnaces (Table 5 ). The main benefits of using PPMS as fuel are: the hygienic disposal, volume reduction, recovery of thermal energy by production of steam or super heated water used further for heat in the paper production operations and power generation, for instance electricity (CANMET, 2005; Gavrilescu, 2008). PPMS combined with other biomass residues from the pulp and paper industry can be an economically attractive option. The use of biomass instead of fossil fuel reduces the overall operating costs at the mills and may lead to fuel self-sufficiency (Gavrilescu, 2008). The report from CANMET (2005) suggests that $5-34 \%$ of the thermal load from fossil fuel may be substituted with PPMS, based on a dry sludge generation rate of 5-15\% of mill production and depending on the net energy consumption of the mill.

One of the main limiting factors of using PPMS as fuel is the high water content (CANMET, 2005; Gavrilescu, 2008). Dewatering the sludge is essential in order to achieve an efficient combustion (CANMET, 2005; Ruohonen et al., 2010). PPMS type affects the dewatering potential: mixed PPMS, which contains higher proportions of cellulosic fibers, is easier to dewater than de-inking PPMS containing ink particles, adhesives, mineral fillers (e.g., kaolin, clay and calcium carbonate) and some cellulosic fibers (Gavrilescu, 2008; Mäkinen et al., 2013). Mechanical dewatering is a common practice resulting in dry contents between $15 \%$ and $50 \%$ whereas the critical level is $\sim 42 \%$ for an efficient and stable combustion (Krogerus et al., 1999; Navaee-Ardeh et al., 2006; Stoica et al., 2009). Biological drying (biodrying) is a practice that consists of drying PPMS with ventilated heat generated by microbial activity from the PPMS itself (Navaee-Ardeh et al., 2006). Biodrying is a promising technology that can be cost-effective (Frei et al., 2006; Navaee-Ardeh et al., 2006).

The low heating value of PPMS is also a limiting factor for combustion (Table 1). Sludge is usually co-fired in small proportions with other residues from paper mills (Gavrilescu, 2008; Stoica et al., 2009). Dewatered PPMS has a heating value commonly ranging between 0 and $6 \mathrm{MJ} \mathrm{kg}^{-1}$ dry solids but can reach up to $25 \mathrm{MJ} \mathrm{kg}^{-1}$ dry solids in rare cases (Table 1; Elliott and Mahmood, 2007). Thus, the common PPMS heating values are low compared, for instance, with wood that has heating values ranging between 17 and $21 \mathrm{MJ} \mathrm{kg}^{-1}$ dry solids (Raitio, 1992; Mabee and Roy, 2003). The heating value of mixed PPMS on dry basis can reach 14-19 $\mathrm{MJ} \mathrm{kg}^{-1}$, which is similar to wood and peat, but only if the sludge is dried to above the critical level of $42 \%$ dryness for good combustion (Navaee-Ardeh et al., 2006). When PPMS is mixed with bark and other lignin residues from the paper mills, the heating value can reach up to $26 \mathrm{MJ} \mathrm{kg}^{-1}$ dry solids (Mabee and Roy, 2003). Combustion in fluidized bed boiler seems to be the most efficient technology to recover energy from PPMS nowadays when considering the low heating value, economic and environmental aspects (Mabee and Roy, 2003; CANMET, 2005; Gavrilescu, 2008).

\subsection{Anaerobic digestion of PPMS: biogas production}

Anaerobic digestion of organic material is a biological process leading to biogas production, which is further used to produce energy. Several types of organic wastes can be processed by anaerobic digestion such as food wastes, municipal biosolids, manure and agricultural wastes (Wang et al., 2008; Magnusson and Alvfors, 2012). Magnusson and Alvfors (2012) investigated the potential of using PPMS as a substrate for biogas production in Sweden. The modeling approach demonstrated that one third of the national biogas production could be achieved if all pulp and paper mills in Sweden would use PPMS as a substrate for anaerobic digestion. This biogas could be used in the transport sector to substitute fossil fuel, which would be a step forward to reduce the impact of this sector on climate warming (Magnusson and Alvfors, 2012).

The modeling approach of Magnusson and Alvfors (2012) encourages to go forward with anaerobic digestion, but biogas production from PPMS is in its infancy and faces technical and economic challenges such as investment costs to install the technology and the appropriate pretreatment leading to an increased biogas yield (Elliott and Mahmood, 2012; Meyer and Edwards, 2014; Ashrafi et al., 2015; Sawatdeenarunat et al., 2015). Actual biogas production from PPMS can be costly for paper mills due to long retention times required by the process and large investments to install efficient bioreactors (Elliott and Mahmood, 2012; Meyer and Edwards, 2014; Sawatdeenarunat et al., 2015). However, the review of Meyer and Edwards (2014) showed that pretreated PPMS leads to increased biogas yield, the most effective methods being thermal and microwave treatments and high-pressure homogenization. Several studies reported on pretreatments that can decrease the retention time and digester size to produce biogas and increase the biodegradability of PPMS (Table 5; Carlsson et al., 2012). Retention times for anaerobic digestion of PPMS in conventional bioreactors usually used for municipal biosolids can range from 20 to 30 days, but a series of pretreatments have been reviewed and applied at the laboratory scale to reduce the retention time down to three to seven days (Elliott and Mahmood, 2007, 2012). Rumen microorganisms were found to have high cellulolytic activity and increase the rate of lignocellulose degradation compared with conventional inocula such as anaerobic sewage sludge (Gijzen et al., 1990; Yue et al., 2013; Sawatdeenarunat et al., 2015). Meyer and Edwards (2014) concluded that future research should focus on the relationships between the anaerobic digestibility and PPMS properties, as biogas yields from non-pretreated PPMS are largely variable. Moreover, more research should be conducted on the anaerobic digestion of primary PPMS as it is the most abundant (Meyer and Edwards, 2014). For instance, in Canadian pulp and paper mills, the average ratio primary:secondary PPMS is estimated to be 70:30 (Elliott and Mahmood, 2005), although it can differ among mills (e.g., 50:50, 40:60 or 67:33; Rashid et al., 2006; Stoica et al., 2009; Meyer and Edwards, 2014; Pervaiz and Sain, 2015). Future research should also focus on the anaerobic digestion of the high content of lignocellulosic material in PPMS (Meyer and Edwards, 2014; Sawatdeenarunat et al., 2015). Thus, new technologies for biogas production from PPMS are emerging and have a concrete potential to be used in the near future.

\subsection{PPMS pyrolysis}

Pyrolysis decomposes organic matter by thermochemical conversion practiced at elevated temperature in the absence of oxygen. The end products of pyrolysis are gases and liquids that are used as fuel (e.g., pyrolytic oil, bio-oil) and a solid residue similar to 
charcoal, commonly named char or biochar. Energy produced by pyrolysis can be used in pulp and paper mills or sustains the pyrolysis itself. For instances, bio-oil can be adapted and used in modified diesel engines, or in conventional engines, if blended with conventional fuel (Ouadi et al., 2012, 2013). There are studies reporting on the use of PPMS as an organic input for pyrolysis (Table 5), another alternative to landfill disposal.

De-inking PPMS can be used for energy recovery by pyrolysis (Lou et al., 2012; Ouadi et al., 2013). Paper mills that recycle paper need high amounts of energy which could be partly produced by pyrolysis of de-inking PPMS at the mill site (Ouadi et al., 2013). Lou et al. (2012) reported that tubular furnace pyrolysis of de-inking PPMS, as a low-quality biomass, produced high-quality fuel and chemicals on a pilot scale. Yields from pyrolysis at $800^{\circ} \mathrm{C}$ of deinking PPMS were $46 \%$ as solids, $30 \%$ as gaseous products $\left(\mathrm{CO}_{2}, \mathrm{CO}\right.$, $\mathrm{CH}_{4}, \mathrm{C}_{2} \mathrm{H}_{4}$ and $\mathrm{H}_{2}$ ) and $24 \%$ as bio-oil (Lou et al., 2012). Thus, some of the gases can be considered as fuel and energy sources (Lou et al., 2012). Ouadi et al. (2013) addressed some of the research questions raised by Lou et al. (2012) by applying an intermediate pyrolysis technique using dried and pelletized de-inking PPMS to produce combined heat and power. Bio-oil produced by this technique had a high heating value of $36-37 \mathrm{MJ} \mathrm{kg}^{-1}$, similar to biodiesel. This biooil was fully miscible with biodiesel and could be used in modified or conventional diesel engines (Hossain et al., 2013; Ouadi et al., 2013). The obtain gases had a heating value of 5-6 $\mathrm{MJ} \mathrm{N} \mathrm{m}^{-3}$ (Ouadi et al., 2013). This intermediate pyrolysis technique did not fully decompose the organic matter from de-inking PPMS, which produced solid residues with a heating value of $3-5 \mathrm{MJ} \mathrm{kg}^{-1}$ (Ouadi et al., 2013). This technique was feasible in principle and could be applied at secondary fiber paper mills with a potential payback period of less than five years in terms of savings from the changes in the disposal practices and energy recovery (Ouadi et al., 2013).

Bio-oil and biochar can be used for other purposes than energy recovery. Components of the bio-oil produced by the pyrolysis of de-inking PPMS have the potential for many uses once isolated (Lou et al., 2012). For instance, toluene can be used as an organic solvent (Lou et al., 2012). The compound o-cresol can be used in the synthesis of antioxidants, adhesives and explosives (Lou et al., 2012). Phenols can be used for the synthesis of phenolic resin and synthetic fiber whereas naphthalene is actually used in spices, plastics, synthetic dyes and as an intermediate for certain drugs (Lou et al., 2012).

\subsection{Bioethanol production from PPMS}

PPMS is a source of lignocellulosic biomass which is used for bioethanol production, classified as second-generation biofuel (Mtui, 2009; Demirbas et al., 2011; Joshi et al., 2011; Nigam and Singh, 2011; Guo et al., 2015). Materials used for second-generation biofuel generally are from the biological or thermochemical processing of agricultural lignocellulosic residues, which are nonedible crop residues (Nigam and Singh, 2011). Second-generation biofuel does not compete for arable lands as it is the case for first-generation biofuel produced from basic feedstock (i.e., sugar, starch, vegetable oil or animal fat; Demirbas et al., 2011; Nigam and Singh, 2011; Guo et al., 2015). Commercial-scale production of second-generation bioethanol from lignocellulosic biomass has recently been reached (Guo et al., 2015), although further research is needed on the processes to be economically viable (Baeyens et al., 2015). Briefly, the review of Baeyens et al. (2015) discussed on five possible interventions that could improve bioethanol production: (1) energy integration within the current production process, (2) use of very high gravity fermentation, (3) development of hybrid systems, (4) final ethanol dewatering to fuel grade and (5) other developments such as cross-flow filtration of bioethanol fermentation broth, novel distillation concepts and improved bioethanol production plant. Thus, PPMS could be an option for the production of second-generation biofuel, which would increase the land use efficiency and have lower environmental impacts compared with first-generation biofuel (Fargione et al., 2008; Nigam and Singh, 2011; Morales et al., 2015; Nanda et al., 2015).

Several studies reported on PPMS conversion into bioethanol (Table 5). Bioethanol production is economically feasible when the process leads to concentrations above $4 \%(\mathrm{w} / \mathrm{v})$ which is achievable and can be surpassed (Zacchi and Axelsson, 1989; Fan et al., 2003; Kang et al., 2010; Zhang and Lynd, 2010). Conversion into bioethanol is controlled by different factors such as the fermentation process, the cellulose and hemicellulose contents and the type of PPMS. Three common fermentation processes have been applied to PPMS for their conversion into bioethanol: separate (or sequential) hydrolysis and fermentation (SHF), simultaneous saccharification and fermentation (SSF), and simultaneous saccharification and co-fermentation (SSCF; Table 5). Moreover, consolidated bioprocessing (CBP), which is the direct microbial conversion of cellulose to ethanol, was recently performed with primary PPMS (Moreau et al., 2015). Different bacteria are used in the SHF, SSF, SSCF and CBP processes affecting the bioethanol yields. Energy required for the conversion can also depend on the process used, as it has been reported for sugarcane bagasse following an exergy analysis (Ojeda et al., 2011). As mentioned, PPMS conversion into bioethanol also depends on the cellulose content as it will proportionally affect the concentrations in fermentable sugars (Monte et al., 2009; Zhang and Lynd, 2010) and the PPMS types (e.g., from Kraft vs. thermo-mechanical processes) affect the bioethanol yields (Monte et al., 2009). Technological advances have been achieved to convert PPMS into second-generation bioethanol. The five interventions discussed by Baeyens et al. (2015) could be considered to upscale the production at low costs for pulp and paper mills.

\subsection{Other energy recovery practices}

Biowastes, biomass and industrial wastewater have been used for the biological production of hydrogen (Mizuno et al., 2000; Noike et al., 2002; Kádár et al., 2003, 2004; Valdez-Vazquez et al., 2005; Kothari et al., 2012; Rama Mohan, 2015; Sharma and Ghoshal, 2015). Hydrogen is an energy carrier (not a fuel) and is one of the potential options to replace fossil fuel, as it is a renewable source with a moderate footprint on GHG emissions following combustion (Kothari et al., 2012; Amoo and Fagbenle, 2014). PPMS has been investigated as a potential residue for the biological production of hydrogen (Table 5). Anaerobic fermentation of PPMS using thermophile bacteria had a hydrogen yield that remained lower compared with other types of sugars, such as glucose and xylose (Kádár et al., 2003, 2004). A successive application of three incubation cycles of PPMS with microbial consortia of solid substrate anaerobic digesters increased the hydrogen yield compared with one incubation cycle (Valdez-Vazquez et al., 2005). This procedure was named as "intermittently vented solid substrate anaerobic hydrogen generation" (IV-SSAH) and claimed to be a feasible strategy for obtaining higher hydrogen yields from the fermentation of industrial solid wastes (Valdez-Vazquez et al., 2005). Moreau et al. (2015) succeeded in producing biohydrogen from primary PPMS fermentation, but their work was conducted at the laboratory scale. Biological production of hydrogen from PPMS and other types of bioindustrial wastes is still in its early stage and need further developments (Kothari et al., 2012). In ideal conditions, about 40\% of the chemical energy in industrial wastewater can be converted into hydrogen energy while by-products from the process (acids and alcohols) require further treatments for full energy recovery, which requires the development of a sustainable technology (Kothari et al., 2012). Isolations of new bacterial strains resulting in efficient hydrogen production should also be performed in 
combination with genetic engineering, reactor optimization and use of low cost raw materials (Kothari et al., 2012).

Technologies involving supercritical water can also produce hydrogen from biomass. Supercritical water has a pressure and temperature that are, at or above their critical points (22.1 MPa and $374{ }^{\circ} \mathrm{C}$ ). In the supercritical phase, water has a high diffusion capacity, a low viscosity and acts as a solvent for organic molecules (Gloyna et al., 1994; Matsumura et al., 2005; Mahmood and Elliott, 2006; Yanik et al., 2007; Zhang et al., 2010). Supercritical water treatments were successfully applied to PPMS to produce energy and remove contaminants (Table 5). Supercritical water gasification (SCWG) produces hydrogen from the biomass with the main advantage of having a high solid conversion, i.e., with low or no formation of char and tar (Xu and Antal, 1998; Matsumura et al., 2005; Yanik et al., 2007; Zhang et al., 2010). SCWG from biomass also produces other gases such as $\mathrm{CH}_{4}, \mathrm{CO}_{2}$ and $\mathrm{CO}$ (Yanik et al., 2007). Unlike combustion and pyrolysis, biomass treated with supercritical water does not need to be dewatered/dried prior to the process (Furness et al., 2000; Mahmood and Elliott, 2006; Zhang et al., 2010), which is one of the benefits of this technology as PPMS dewatering can be costly. Zhang et al. (2010) reported that secondary PPMS treated by SCWG had the highest gas yield with $37.7 \%$ of PPMS (on dry basis) converted into gases, from which hydrogen yield was $14.5 \mathrm{~mol} \mathrm{H}_{2} \mathrm{~kg}^{-1}$. Gas yield from secondary PPMS was higher than municipal biosolids treated by SCWG (Zhang et al., 2010). Supercritical water oxidation (SCWO) of secondary PPMS has been reviewed by Mahmood and Elliott (2006). SCWO produces water, $\mathrm{CO}_{2}$, nitrogen (without the formation of $\mathrm{NO}_{\mathrm{X}}$ and $\mathrm{SO}_{\mathrm{X}}$ ), acids and salts (Mahmood and Elliott, 2006; Wang et al., 2008). SCWO was efficient in removing contaminants from various types of PPMS, which could be applied in sludge remediation technology (Crain et al., 2000). SCWO also has the potential to produce energy (hot water and high-pressure steam) as reported for the treatment of municipal biosolids (Svanström et al., 2004; Wang et al., 2008). SCWG and SCWO processes applied on various types of wet biomass (e.g., sewage sludge, wood sawdust and glucose) were reported to be effective for the production of hydrogen (Xu et al., 1996; Xu and Antal, 1998).

Direct liquefaction is a one-step process that converts biomass into liquid fuel without the gasification step (Behrendt et al., 2008). Direct liquefaction is practiced at temperatures varying between 150 and $420^{\circ} \mathrm{C}$, lower than pyrolysis, and pressures ranging from 0.1 to $24 \mathrm{MPa}$ (Behrendt et al., 2008). Water can be an effective solvent for liquefaction, which is one of the benefits when the process is applied to PPMS as dewatering is not required (Table 5; Zhang et al., 2011). Catalysts are also used during liquefaction in order to improve the fuel yield and decrease the formation of char (Xu and Lancaster, 2008; Zhang et al., 2011). Xu and Lancaster (2008) performed liquefaction experiments on dried secondary PPMS powder in suspension in distilled water using a bomb reactor (temperature range of $250-380^{\circ} \mathrm{C}$ ), with and without catalysts. Yields of heavy and water soluble oil were affected by the liquefaction temperature, residence time, initial biomass concentration, catalysts and liquefaction air (inert or reducing). The highest heavy oil yield was $26 \%$ with a heating value above $35 \mathrm{MJ} \mathrm{kg}^{-1}$, obtained in the presence of a catalyst $\left(0.1 \mathrm{M} \mathrm{Ca}(\mathrm{OH})_{2}\right)$ and a pressurized hydrogenous (2 MPa of $\mathrm{H}_{2}$ ) air (Xu and Lancaster, 2008). Xu and Lancaster (2008) pointed out that they first aimed to understand the controlling factors of the process and that future work should be realized at the commercial-scale, where secondary PPMS is treated as received (i.e., without any drying treatment). Zhang et al. (2011) experimented on the co-liquefaction of various ratios of secondary PPMS mixed with waste newspapers using different catalysts. The heavy oil yield increased at temperatures ranging between 250 and $350^{\circ} \mathrm{C}$ with a maximum of $28 \%$ at $350{ }^{\circ} \mathrm{C}$. The heavy oil yield increased to $34.4 \%$ when using the most effective catalyst $\mathrm{HCO}_{2} \mathrm{H}$ (Zhang et al.,
2011). Their experiments were performed in a bench-scale batch reactor.

\section{Integration of PPMS in materials}

There are numerous options for using PPMS as a material component (Table 6). It is integrated in a variety of materials such as biocomposites of wood and plastic and other construction materials. PPMS is also used in the adsorbent-absorbent productions.

\subsection{Biocomposite: PPMS in wood and plastic materials}

PPMS contains organic (e.g., cellulose fibers) and inorganic components (e.g., clay, calcium carbonate) that improves the properties of composites such as polypropylene, polyethylene and rubber (Table 6). For instance, PPMS can replace the inorganic fillers in the production of rubber and polypropylene-ethylene propylene diene terpolymer (PP-EPDM; used in rubber industry) composites to improve the product properties and reduce the production cost (Ismail et al., 2005, 2006). Their incorporation increased the tensile modulus (i.e., Young's modulus or elasticity) but decreased the tensile strength and elongation at break (Ismail et al., 2005, 2006). The sludge also increased the thermal stability above $500{ }^{\circ} \mathrm{C}$ and water absorption of PP-EPDM composites (Ismail et al., 2005).

PPMS can be used in the composition of wood and polyethylene materials (Table 6). Soucy et al. (2014) determined the impact of using primary and secondary PPMS, from thermo-mechanical, chemithermomechanical and Kraft pulping, on the development of high density polyethylene-wood-plastic composites (HDPE-WPC). HDPE-WPC properties were better when using PPMS from Kraft pulping, with its high cellulosic content and longer fibers, compared with PPMS produced by thermo-mechanical and chemithermomechanical pulping (Soucy et al., 2014). The composite strength, water absorption and thickness swelling improved by increasing PPMS proportion (Soucy et al., 2014). However, Hamzeh et al. (2011) reported that water absorption and thickness swelling were decreased with increasing PPMS proportion using different PPMScomposite formulations than Soucy et al. (2014). Primary PPMS fibers reinforced HDPE-WPC whereas secondary PPMS content negatively affected the physical and mechanical HDPE-WPC properties (Soucy et al., 2014).

PPMS can also be used to substitute wood in the production of pallets (Table 6). In the U.S., pallets made of wood represent approximately $95 \%$ of the pallet market share and the annual production is estimated to 450 million new pallets (Kim et al., 2009). The substitution of $10 \%$ of wood particle by PPMS resulted in pallets having the same mechanical properties than pallets made with only wood particles and meeting the minimum requirements for standard manufacturing (Kim et al., 2009).

Some studies demonstrated that PPMS can be incorporated (partly or totally) in the production of medium density fiberboards (MDF) and particle boards (Table 6). Primary and secondary PPMS have natural adhesive properties enabled by their fiber and protein contents, which can be used as a fiber source and particle binders in MDF and particle board productions (Migneault et al., 2011a, 2011b; Pervaiz and Sain, 2011, 2012; Xing et al., 2012a, 2012b, 2013). Secondary PPMS was tested as a co-adhesive in MDF resin (Migneault et al., 2011b; Xing et al., 2012a, 2012b, 2013), its use reduced the formaldehyde emissions by up to $68 \%$ compared with control panels and did not affect the internal bond strength of the MDF product (Migneault et al., 2011b). However, the short fibers length and the high non-fibrous content of the secondary PPMS negatively affected the mechanical properties of the MDF, although it still met the highest standards of the American National Standard Institute (ANSI; Migneault et al., 2011b). On the other hand, tests 
Table 6

Summary of the emerging options in which pulp and paper mill sludge (PPMS) is integrated in materials.

\begin{tabular}{|c|c|c|}
\hline Type of PPMS & Emerging options: materials in which PPMS is integrated & Reference \\
\hline \multicolumn{3}{|l|}{ Biocomposite: wood and plastic materials } \\
\hline & -Polypropylene (PP) composites: & \\
\hline -De-inking & - Coupled with PP and maleic anhydride grafted polypropylene (MAPP) & Qiao et al. (2004) \\
\hline$-\mathrm{ND}$ & - Tested as a filler/reinforcement & Girones et al. (2010) \\
\hline$-N D$ & $\begin{array}{l}\text { - Thermoplastic polymer composites: } \\
\text { - PP } \\
\text { - High impact polypropylene (HIPP) } \\
\text { - High-density polyethylene (HDPE) } \\
\text { - Low-density polyethylene (LDPE) }\end{array}$ & Son et al. (2004) \\
\hline$-\mathrm{ND}$ & $\begin{array}{l}\text {-Polypropylene-ethylene propylene diene terpolymer composites } \\
\text { (PP-EPDM composites) }\end{array}$ & Ismail et al. (2005) \\
\hline$-\mathrm{ND}$ & -Rubber composites & Ismail et al. (2006) \\
\hline \multirow[t]{5}{*}{-All types } & -Wood-plastic composites: & Hamzeh et al. (2011) \\
\hline & - High density polyethylene-wood-plastic composites (HDPE-WPC) & Hamzeh et al. (2012) \\
\hline & & Huang et al. (2012) \\
\hline & & Migneault et al. (2014) \\
\hline & & Soucy et al. (2014) \\
\hline$-\mathrm{ND}$ & -Wood pallets (i.e., green composite pallets) & Kim et al. (2009) \\
\hline \multirow[t]{8}{*}{-All types } & -Medium density fiberboards (MDF): & Davis et al. (2003) \\
\hline & - Used as a fiber source and adhesive & Geng et al. (2007a) \\
\hline & & Geng et al. (2007b) \\
\hline & & Migneault et al. (2010) \\
\hline & & Migneault et al. (2011a) \\
\hline & & Migneault et al. (2011b) \\
\hline & & Pervaiz and Sain $(2011,2012)$ \\
\hline & $\begin{array}{l}\text {-Particle boards: } \\
\text { - Used a fiber source and particle binder }\end{array}$ & \\
\hline \multirow[t]{2}{*}{-Secondary } & & Xing et al. (2012a, 2012b) \\
\hline & & Xing et al. (2013) \\
\hline $\begin{array}{l}\text {-From chemimechanical and neutral } \\
\text { sulfite semichemical pulping }\end{array}$ & & Taramian et al. (2007) \\
\hline -Primary & -Nanocellulose (i.e., nano sized cellulose) & Leão et al. (2012) \\
\hline \multirow[t]{2}{*}{$-N D$} & -Lactic acid leading to bioplastic production & Tong et al. (2004) \\
\hline & & Shabna et al. (2011) \\
\hline \multicolumn{3}{|l|}{ Cement and asphalt productions } \\
\hline & -Integrated in cement, concrete, clinker and brick productions: & \\
\hline -Secondary & $\begin{array}{l}\text { - Used as secondary raw materials to produce cement and clinker and } \\
\text { tested in mortar preparations }\end{array}$ & Buruberri et al. (2015) \\
\hline -De-inking & - Addition in cement mortar & Yan et al. (2011) \\
\hline -From Kraft pulping & - Addition in clay brick & Demir et al. (2005) \\
\hline$-\mathrm{ND}$ & - Replacement of the mineral filler material in concrete & Ahmadi and Al-Khaja (2001) \\
\hline -De-inking & -Integrated as fiber additive in asphalt & Mari et al. (2009) \\
\hline \multirow{2}{*}{\multicolumn{3}{|c|}{$\begin{array}{l}\text {-Sludge from the final filter cakes from } \\
\text { the wastewater treatment } \\
\text { Adsorbent-absorbent productions }\end{array}$}} \\
\hline & & \\
\hline & -Adsorbents for environmental decontamination: & \\
\hline -Secondary & $\begin{array}{l}\text { - Activated carbon made from pyrolyzed PPMS and } \mathrm{KOH} \text {-activation } \\
\text { tested for the adsorption of metals (copper, cadmium and chromium) }\end{array}$ & Kang et al. (2006) \\
\hline \multirow[t]{2}{*}{-Mixed } & - Removal of heavy metals from contaminated water & Calace et al. (2002) \\
\hline & & Calace et al. (2003) \\
\hline -De-inking & $\begin{array}{l}\text { - Comparison between pyrolyzed PPMS and the commercial activated } \\
\text { carbon BPL on the adsorptive capacity for mercury }\end{array}$ & Almquist and Qin (2013) \\
\hline -De-inking & - Pyrolyzed PPMS for the removal of copper ions and malachite green & Méndez et al. (2009a) \\
\hline -Sludge from eucalyptus virgin pulp & from contaminated water & Méndez et al. (2010) \\
\hline \multicolumn{3}{|l|}{ mill } \\
\hline -ND & $\begin{array}{l}\text { - Paper mill waste tested for the removal of heavy metals from } \\
\text { contaminated water }\end{array}$ & Lister and Line (2001) \\
\hline$-\mathrm{ND}$ & - PPMS tested for the removal of lead from contaminated soil & He et al. (2010) \\
\hline$-\mathrm{ND}$ & $\begin{array}{l}\text { - Activated carbon made from PPMS to remove dyes from dying, } \\
\text { textile, leather, paint and plastic industries }\end{array}$ & Li et al. (2011) \\
\hline$-\mathrm{ND}$ & $\begin{array}{l}\text { - Pyrolysis and physical activation of PPMS tested for } \mathrm{NO}_{2} \text { removal } \\
\text {-Absorbents: }\end{array}$ & Hofman and Pietrzak (2012) \\
\hline -De-inking & $\begin{array}{l}\text { - BIODAC granules: carrier for microorganisms (bacteria and fungi) } \\
\text { tested for soil bioremediation }\end{array}$ & Ilyina et al. (2000) \\
\hline -De-inking & - PPMS tested as animal bedding & Beauchamp et al. (2002) \\
\hline -De-inking & - Treated PPMS (hydrophobation, mechanical and thermal treatments) & Likon et al. (2009) \\
\hline -From chemo-mechanical pulping & $\begin{array}{l}\text { tested as a substitute of mineral and synthetic absorbents for the } \\
\text { removal of hydrophobic substances from contaminated water }\end{array}$ & \\
\hline$-\mathrm{ND}$ & $\begin{array}{l}\text { - A patent for a cellulose absorbent made from a fibrous cellulose } \\
\text { component including wood fibers, fiber pile, chip wash solids, fiber } \\
\text { waste and wood fiber fines }\end{array}$ & Eifling and Ebbers (2006) \\
\hline
\end{tabular}

ND: PPMS type not determined or specified in the study. 
on different secondary PPMS proportions (Xing et al., 2012a, 2012b, 2013) only partly met the ANSI standards, making proportions of secondary PPMS, used as a co-adhesive in MDF resin, a critical issue in order to meet the highest product standards. Migneault et al. (2011a) evaluated the properties of binderless fiberboard made from combinations of primary and secondary PPMS in different ratios. Among the ratios tested, the secondary:primary PPMS ratio of 3:7 from thermo-mechanical pulping was the only one meeting the ANSI standards for basic hardboard (Migneault et al., 2011a).

There is emerging research on the extraction of nanocellulose from primary PPMS by using high pressure defibrillation and chemical purification processes (Table 6). The extracted nanofibers can be used to form a nanocellulose-polyurethane nanocomposite having a wide range of biomedical and biotechnological applications (Leão et al., 2012). PPMS could be integrated in bioplastic production (Table 6; Vijayakumar et al., 2008) and substitute fossil-based plastic. Studies reported that PPMS could be used as a cellulosic source and growing medium for bacteria producing lactic acid entering in the synthesis of biodegradable polylactic acid leading to bioplastic production (Tong et al., 2004; Vijayakumar et al., 2008).

\section{2. $P P M S$ integrated in cement and asphalt productions}

Studies have shown that PPMS can be integrated in cement, clinker, mortar, concrete and asphalt productions (Table 6). Ahmadi and Al-Khaja (2001) reported that PPMS can substitute mineral fillers in concrete mixes for non-structural masonry construction. Replacement of mineral fillers by PPMS increased concrete water absorption and met the compressive strength requirements for concrete uses in masonry (Ahmadi and Al-Khaja, 2001). Yan et al. (2011) demonstrated that de-inking PPMS has the potential to be used as an additive in cement mortar systems for masonry products. The optimal addition of $2.5 \%$ of de-inking PPMS in cement increased water absorption and did not significantly affect the mechanical and physical properties (Yan et al., 2011). Moreover, de-inking PPMS increased cement setting time, indicating that it could be used as a retarding chemical admixture (Yan et al., 2011). Buruberri et al. (2015) also showed that it is possible to incorporate a large amount of secondary PPMS in clinker preparation. Mari et al. (2009) tested PPMS produced by four paper mills for its use as a fiber additive in stone mastic asphalt in the Philippines. An addition of $0.3-0.5 \%$ of any of the PPMS tested in the stone mastic asphalt met the standards for medium and heavy traffic road pavements, according to the Department of Public Works and Highways in the Philippines (Mari et al., 2009).

\subsection{PPMS used in adsorbent-absorbent productions}

PPMS was tested as such or as a precursor to be used as an adsorbent-absorbent in environmental decontamination, soil bioremediation and animal bedding (Table 6). Motives to use PPMS as an adsorbent-absorbent are based on environmental and economic reasons (Li et al., 2011; Almquist and Qin, 2013). Using PPMS as an adsorbent-absorbent represents an environment-friendly alternative to the conventional disposal in landfill sites. PPMS has a low cost and is easily available to produce adsorbent-absorbent compared with the expensive commercial products (Li et al., 2011; Almquist and Qin, 2013).

The use of PPMS as an adsorbent for environmental decontamination, either as a raw material or after being transformed by pyrolysis and/or physical activation, was demonstrated in several studies (Table 6). PPMS could be an interesting precursor for adsorbents, considering the high carbon content and proportion in cellulose fibers. Contaminated water can contain large amount of heavy metals that need to be removed (Méndez et al., 2009a). Conventional methods such as precipitation, ion-exchange and adsorption with commercial activated carbon are not efficient and too costly when dealing with a large amount of contaminated water (Méndez et al., 2009a). Pyrolyzed de-inking PPMS and PPMS produced by an eucalyptus virgin pulp mill were tested as precursors for adsorbents that could remove copper ions $\left(\mathrm{Cu}^{2+}\right)$ and malachite green from contaminated water (Méndez et al., 2009a, 2010). Both types of pyrolyzed PPMS led to mesoporous and high microporous adsorbents, respectively (Méndez et al., 2009a). Adsorbent made from pyrolyzed de-inking PPMS had the highest capacity to remove copper ions, which could be due to the elevated oxygenated surface groups, high average pore diameter, elevated superficial charge density and calcium and magnesium exchange contents (Méndez et al., 2009a). Water pH was also increased by both types of adsorbents (Méndez et al., 2009a). They also both were able to adsorb malachite green but the affinity and adsorption intensity was highest for pyrolyzed PPMS from eucalyptus mill (Méndez et al., 2010). Calace et al. (2003) reported that mixed PPMS was able to retain lead, copper, silver and cadmium ions from water and that the sorptive capacity was increased with increasing $\mathrm{pH}$. Thus, mixed PPMS could be used as an adsorbent matrix to remove heavy metals from contaminated water and increase the $\mathrm{pH}$ value (Calace et al., 2003). Li et al. (2011) tested PPMS as a precursor of activated carbon for its capacity to remove dyes (cationic methylene blue and anionic reactive red) released from dying, textile, leather, paint and plastic industries, as an alternative to the more expensive, but commercially available, activated carbon. PPMS was converted into activated carbon by physical activation with steam (Li et al., 2011). The activated carbon made from PPMS showed better adsorptive capacities than the commercially available activated carbon for both types of dyes tested (Li et al., 2011). PPMS can also be used as an adsorbent in air decontamination. For instance, Almquist and Qin (2013) compared pyrolyzed de-inking PPMS and the commercial activated carbon BPL (Calgon Carbon, Pittsburgh, PA) in their adsorptive capacity for mercury. Such adsorbents are needed in coal-fired power plants that are responsible for more than $50 \%$ of the anthropogenic mercury emissions in the United States (Almquist and Qin, 2013). Adsorbent made from pyrolyzed de-inking PPMS at $750^{\circ} \mathrm{C}$ and $950^{\circ} \mathrm{C}$ demonstrated higher mercury adsorption capacities compared with commercial BPL mainly due to pore size distribution (Almquist and Qin, 2013). Pyrolyzed de-inking PPMS with pore sizes between 25 and $100 \mathrm{~nm}$ favored the kinetics for mercury compared with the pore sizes of less than $10 \mathrm{~nm}$ for commercial BPL (Almquist and Qin, 2013). Hofman and Pietrzak (2012) showed that adsorbent made from the pyrolysis and physical activation of PPMS was efficient to remove $\mathrm{NO}_{2}$ in wet and dry conditions.

PPMS has absorptive properties that could be used in soil bioremediation and animal bedding (Table 6). The absorptive capacity of PPMS can be used as a vector to release chemicals and inoculated bacteria in agriculture and horticulture (Ilyina et al., 2000). De-inking PPMS was tested to be a carrier for microorganisms for potential use in soil bioremediation. Ilyina et al. (2000) reported that granulated de-inking PPMS was able to sustain inoculated microorganisms for at least two months. However, de-inking PPMS decreased soil capacity to retain moisture, which is likely due to the PPMS porosity that favored water evaporation (Ilyina et al., 2000). Beauchamp et al. (2002) investigated the animal product safety and performance in presence of de-inking PPMS. One of the treatments consisted of feeding broilers with 0,5 or $10 \%$ of their ration with de-inking PPMS. Broilers and pigs were also subjected to a growth experiment in which bedding treatments were de-inking PPMS compared with wood shavings (Beauchamp et al., 2002). Results showed that blood and bone contents in aluminum and copper were not affected by de-inking PPMS for both broilers and pigs (Beauchamp et al., 2002). Moreover, feeding and bedding with de-inking PPMS did not affect the polycyclic aromatic hydrocarbon 
contents of liver, fat, meat or urine, neither the growth for broilers and pigs. This study showed that de-inking PPMS could be safely used as low cost material for animal bedding.

\section{Determinants of GHG emissions from PPMS management practices: knowns and unknowns}

Some studies presented in this paper provide information on known determinants of GHG emissions from PPMS management practices (Table 7). This information could constitute a basis on which upcoming research challenges should focus in order to increase the comprehension of known GHG determinants and reveal unknown factors. Future research should aim to increase the amount of robust GHG emission assessments from the life cycles of various PPMS management practices (Table 7).

The GHG emissions from PPMS landfilling can be estimated using approved methods but the uncertainties are large and no measurements at the industrial scale are available for all countries neither for each type of PPMS (Table 7; NCASI, 2005; IPCC, 2006; Faubert et al., 2015). It is crucial to perform such measurements that would isolate the PPMS contributions to the GHG emissions from a landfill site. As a common baseline scenario for several jurisdictions, a pulp and paper mill that would reduce the amount of PPMS managed by landfilling could generate tradable GHG offset credits on carbon markets, such as those of the WCI and European Union Emissions Trading Systems (EU ETS). In this context, reliable comparisons of the GHG assessments between PPMS landfilling and alternative practices would be necessary. These assessments should be based on measurements, follow the six principles of a project-based GHG reductions (relevance, completeness, consistency, transparency, accuracy and conservativeness) and demonstrate additionality to the baseline scenario (WBCSD, 2005).

Although literature on PPMS land application in agriculture is relatively abundant (Tables 2 and 3), the impacts on GHG emissions remain largely unknown (Table 7). Part of the nitrogen contained in PPMS and other organic fertilizers is emitted from agricultural soils as $\mathrm{N}_{2} \mathrm{O}$ (IPCC, 2006; Rochette et al., 2008). In Canada, agriculture is responsible for $70 \%$ of the anthropogenic $\mathrm{N}_{2} \mathrm{O}$ emissions (Environment Canada, 2015). $\mathrm{N}_{2} \mathrm{O}$ emissions from agricultural soils are caused by denitrification and nitrification processes driven by a myriad of factors such as the form under which nitrogen is present in the soil (e.g., $\mathrm{NH}_{4}, \mathrm{NO}_{3}$ ), labile carbon and water contents, organic matter, $\mathrm{pH}$ and meteorological factors (Rochette et al., 2008; Thangarajan et al., 2013). The percentage of applied nitrogen lost as $\mathrm{N}_{2} \mathrm{O}-\mathrm{N}$ emissions from agricultural soils is called the fertilizer-induced $\mathrm{N}_{2} \mathrm{O}$ emission factor (FIEF; Bouwman, 1996, 1998; IPCC, 2006; Rochette et al., 2008; Chantigny et al., 2013). The IPCC guidelines for national greenhouse gas inventories (IPCC, 2006) ruled on a default FIEF of $1 \%$ for all types of nitrogen additions (i.e., mineral and organic amendments). Uncertainties on this default FIEF are large ranging from 0.3 to 3\% (IPCC, 2006). Moreover, the studies preoccupied with the FIEF reported that it varies according to the type of nitrogen addition (mineral vs. organic; Baggs et al., 2002; Gregorich et al., 2005; Rochette et al., 2008; Chantigny et al., 2013; Thangarajan et al., 2013). So far, FIEFs from PPMS land application have only been reported by few studies (Baggs et al., 2002; Chantigny et al., 2013; Faubert et al., 2015). A 2yr mean FIEF of $1 \%$ was measured for mixed PPMS applied on a soil cropped with wheat (Faubert et al., 2015). Chantigny et al. (2013) measured 2-year mean FIEFs of $0.9 \pm 0.2 \%$ and $-0.4 \pm 0.2 \%$ for mixed and de-inking PPMS applications, respectively (the negative FIEF means that de-inking PPMS application had lower $\mathrm{N}_{2} \mathrm{O}$ emissions than the control). The $\mathrm{N}_{2} \mathrm{O}$ emissions from mixed and de-inking PPMS applications were also compared with other types of mineral and organic amendments on a corn crop. FIEFs from mixed and de-inking PPMS applications were lower than from nitrogen fertilization using mineral fertilizer and pig slurry (2-year mean FIEFs: mineral fertilizer, $4.2 \pm 0.9 \%$; pig slurry, $2.5 \pm 0.5 \%$; Chantigny et al., 2013). On the other hand, Baggs et al. (2002) reported a 5\% FIEF from PPMS application on a soil that had been cropped with calabrese (Brassica oleracea italic var. cymosa) after two years $\left(\mathrm{N}_{2} \mathrm{O}\right.$ emissions measured over 67 days). Such results are important as it shows that $\mathrm{N}_{2} \mathrm{O}$ emissions from PPMS land application on agricultural soils can differ considerably from the $1 \%$ default value currently used (IPCC, 2006). Research on $\mathrm{N}_{2} \mathrm{O}$ emission dynamics from PPMS land application is in its infancy and must be pursued. More data on GHG emissions linked to a variety of agricultural practices, a large array of soils, crop types and PPMS characteristics are needed (Table 7). Using PPMS as a soil amendment can be a GHG offset when it substitutes mineral fertilizers. Such usage avoids scope 3 GHG emissions due to the life cycle of mineral fertilizer production (Wood and Cowie, 2004; Murray et al., 2008; Brown et al., 2010).

One study reported on GHG emissions induced by PPMS application in silviculture, in managed forest stands (Table 7). Chuan-kuan et al. (2005) observed that PPMS (ratio $\mathrm{C}: \mathrm{N}=23: 1$, type not specified) application in a sugar maple (Acer saccharum) forest, significantly increased maximum soil $\mathrm{CO}_{2}$ emissions by $91 \%$ and $126 \%$ compared with the mineral fertilizer treatment and control, respectively. As the $\mathrm{CO}_{2}$ released from the PPMS decomposition in soil is from biogenic sources it may not be included in a GHG emission inventory (IPCC, 2006). No studies were found on the effect of PPMS application on $\mathrm{N}_{2} \mathrm{O}$ and $\mathrm{CH}_{4}$ emissions from forest soils. The default values for $\mathrm{N}_{2} \mathrm{O}$ emissions from managed temperate and boreal organic nutrient rich and poor forest soils are $0.6 \mathrm{~kg}$ $\mathrm{N}_{2} \mathrm{O}-\mathrm{N} \mathrm{ha}^{-1}$ (uncertainty range of $0.16-2.4$ ) and $0.1 \mathrm{~kg} \mathrm{~N}_{2} \mathrm{O}-\mathrm{N} \mathrm{ha}^{-1}$ (uncertainty range of $0.02-0.3$ ), respectively (IPCC, 2006). Further research should be conducted on the effect of PPMS application on forest soil $\mathrm{N}_{2} \mathrm{O}$ emissions notably to assess if they would be within the range of the IPCC (2006) default emission factors. Moreover, GHG emissions from the application in forest stands should be estimated by life cycle analyses including all emissions related to the machinery required by this practice, such as trucks transporting PPMS from the paper mill to the forest sites and so on. PPMS spreading also requires that some temporary trails are used in the forest by machinery, which can have an effect on the whole forest management and final stand production. Nevertheless, as discussed for land application in agriculture, PPMS application in managed forest stands could represent a GHG offset because it reduces the use of mineral fertilizers, which production generates GHGs (Wood and Cowie, 2004; Murray et al., 2008; Brown et al., 2010). Increased forest productivity from PPMS application can result in a net carbon uptake from the atmosphere. Under certain conditions, this could be considered as a carbon absorption, which can be offset from life cycle emissions. More research is needed on that particular topic (Table 7).

Literature on GHG emissions from PPMS application for land reclamation is scant (Table 7). This practice may favor true carbon sequestration (where $\mathrm{CO}_{2}$ is removed from the atmosphere and sequestrated into the vegetation and soil) by increasing overall soil qualities and consequent increase in net primary productivity from reclaimed soils that are poor in nutrients and organic matter content (Larney and Angers, 2012). Larney and Angers (2012) underlined the need for studies on the related GHG emissions, using life cycle analyses, as does the present review. GHG emission assessments of PPMS composting, using life cycle analyses, are also non-existent, to the best of our knowledge (Table 7). This issue deserves more attention as this practice is a potential alternative to landfill disposal. Two studies on the management of municipal wastes and biosolids showed that composting can reduce, or maintain similar GHG emissions, when compared to current 
Table 7

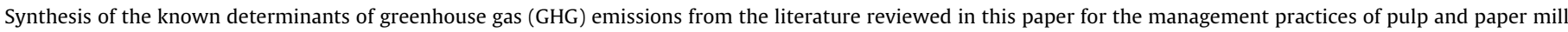

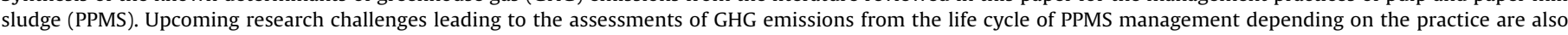
presented.

\begin{tabular}{|c|c|c|}
\hline $\begin{array}{l}\text { PPMS management } \\
\text { practice }\end{array}$ & Determinants of GHG emissions & $\begin{array}{l}\text { Upcoming research challenges leading to the assessments of } \\
\text { GHG emissions from the life cycles of PPMS management } \\
\text { practices }\end{array}$ \\
\hline
\end{tabular}

PPMS landfilling

-Direct GHG emission estimations using the first order of decay method (FOD; NCASI, 2005; IPCC, 2006):

- The FOD method is recommended by the IPCC guidelines for greenhouse gas inventories (IPCC, 2006) to estimate GHG emissions from solid waste disposal. The calculation tool of NCASI (2005) estimates the GHG emissions from landfill sites of the pulp and paper industry using a simplified approach of the FOD method. In this simplified approach, the degradable organic carbon (DOC) in wastes is one of the main parameters affecting $\mathrm{CH}_{4}$ emissions (NCASI, 2005; IPCC, 2006). The FOD method assumes that the DOC in waste decays throughout a few decades and produces $\mathrm{CH}_{4}$ and $\mathrm{CO}_{2}$ emissions (IPCC, 2006). - GHG emission determinants related to the use of the FOD method are attributable to the uncertainties associated with the method itself, activity data and parameters (IPCC, 2006): - GHG determinants related to the method: - $\mathrm{CH}_{4}$ emissions are induced by a series of complex chemical reactions and a first-order decay reaction may not always occur in nature. Thus, reactions may involve higher orders or be limited according to specific landfill site conditions, access to water and local variations in populations of bacteria (IPCC, 2006).

- GHG determinants related to the activity data and FOD parameters:

- Amount, composition and water content of wastes affect the DOC used to estimate $\mathrm{CH}_{4}$ emissions from landfill sites (IPCC, 2006).

-Theoretical estimations of aerobic and anaerobic decomposition (Buswell and Mueller, 1952; Likon et al., 2009; Likon and Saarela, 2012; Likon and Trebše, 2012):

- Estimated GHG emissions from low-ash PPMS:

- $2.69 \mathrm{Mg} \mathrm{CO}_{2} \mathrm{Mg}^{-1}$ low-ash PPMS

- $0.24 \mathrm{Mg} \mathrm{CH}_{4} \mathrm{Mg}^{-1}$ low-ash PPMS

-Estimations and measurements of GHG emissions from PPMS landfilling:

- $\mathrm{CH}_{4}$ generation potential used in Sweden in the FOD method: $0.045 \mathrm{Mg} \mathrm{CH}_{4} \mathrm{Mg}^{-1}$ PPMS (national value for any type of PPMS; Swedish EPA, 2015); this value is also reported in the simplified FOD method of NCASI (2005).

- Measurements at the pilot scale, cumulated GHG emissions

$\left(\mathrm{N}_{2} \mathrm{O}\right.$ and $\mathrm{CH}_{4}$ ) over two snow-free seasons (Faubert et al.

2015):

- $0.90 \mathrm{Mg} \mathrm{CO}_{2}$ equivalent $\mathrm{Mg}^{-1}$ dry mixed PPMS

- $0.017 \mathrm{Mg} \mathrm{CO}_{2}$ equivalent $\mathrm{Mg}^{-1}$ dry primary PPMS

-No methods exist to estimate direct $\mathrm{N}_{2} \mathrm{O}$ emissions from solid waste disposal because they were assumed not significant by the IPCC guidelines for greenhouse gas inventories (IPCC, 2006). However, certain determinants could induce significant $\mathrm{N}_{2} \mathrm{O}$ emissions from PPMS landfilling:

- C: $\mathrm{N}$ ratio affects $\mathrm{N}_{2} \mathrm{O}$ emission in soils (Thangarajan et al.,

2013): a low C: $N$ ratio may lead to $\mathrm{N}_{2} \mathrm{O}$ release.

- $\mathrm{N}_{2} \mathrm{O}$ emissions were measured at the pilot scale from

primary and mixed PPMS (Faubert et al., 2015).

- $\mathrm{N}_{2} \mathrm{O}$ emissions are estimated from the landfilling of

municipal biosolids in the biosolids emissions assessment

model (BEAM; Brown et al., 2010).

-GHG emissions to consider in a life cycle approach:

- PPMS transportation to the landfill site (e.g., distance,

machinery type).

- Energy used (e.g., fossil fuel consumption, electricity) for

PPMS handling and facility maintenance of the landfill site.

-Assessment of GHG emissions from landfill sites should include the monitoring of the specific site conditions such as meteorological variables (e.g., precipitations, atmospheric pressure), air and soil moisture/temperature and water table depth. Analyses of the microorganism communities may also be recommended to determine the local variations on the site leading to methanogenesis and methanotrophy (Le Mer and Roger, 2001).

-An accurate monitoring of the weight of PPMS and other pulp and paper wastes disposed at the landfill site should be performed in order to produce reliable GHG emission assessments (IPCC, 2006).

-DOC for industrial waste is poorly known (IPCC, 2006). Thus, DOC measurements of each type of PPMS (i.e., primary, secondary, mixed and de-inking) as well as other wastes should be achieved for each landfill to increase the accuracy of $\mathrm{CH}_{4}$ emissions estimated by the FOD method.

-These theoretical estimations of $\mathrm{CO}_{2}$ and $\mathrm{CH}_{4}$ emissions need to be validated based on measurements from landfill sites, at the industrial scale.

-The $\mathrm{CH}_{4}$ generation potential used in Sweden is specific to this country and information on those values is scarcely known for other countries. Faubert et al. (2015) measured GHC emissions at the pilot scale, which could be underestimated as the experimental set-up could not simulate all operating conditions of a landfill site, at the industrial scale. Thus, $\mathrm{CH}_{4}$ emissions should be measured at the industrial scale, on real landfill sites, if the objective is to produce accurate GHG emission assessments that represent each type of PPMS. Emission factors should be available at the country scale and preferably at the local scale (for a mill), as landfill operating conditions can vary among mills. The most important techniques to measure direct GHG emissions are (1) static or forced flux chamber measurements, (2) mass balance methods, (3) micrometeorological measurements and (4) plume measurements (IPCC, 2006).

-Secondary and mixed PPMS have low $\mathrm{C}: \mathrm{N}$ ratio that may lead to significant $\mathrm{N}_{2} \mathrm{O}$ emissions. Thus, measurements of $\mathrm{N}_{2} \mathrm{O}$ emissions from each type of landfilled PPMS should be perform to prevent an underestimation of the GHG emissions.

-GHG emissions related to all operations involved in PPMS handling and site maintenance should be included in an assessment using a life cycle analysis approach. 
Table 7 (Continued)

\begin{tabular}{|c|c|c|}
\hline $\begin{array}{l}\text { PPMS management } \\
\text { practice }\end{array}$ & Determinants of GHG emissions & $\begin{array}{l}\text { Upcoming research challenges leading to the assessments of } \\
\text { GHG emissions from the life cycles of PPMS management } \\
\text { practices }\end{array}$ \\
\hline
\end{tabular}

\section{Land application of PPMS}

Agriculture

-Soil and agricultural practices:

- Soil texture influences $\mathrm{N}_{2} \mathrm{O}$ emissions: fine-textured soils were estimated to induce $\mathrm{N}_{2} \mathrm{O}$ emissions that are $50 \%$ higher than those from coarse- and medium-textured soils in eastern Canada (Rochette et al., 2008).

- Soil tillage affects $\mathrm{N}_{2} \mathrm{O}$ emissions (Gregorich et al., 2005; Rochette et al., 2008).

- Meteorological conditions: e.g., precipitations increase soil water content, which is a favorable condition for $\mathrm{N}_{2} \mathrm{O}$ emissions (Rochette et al., 2008).

- Factors controlling direct and indirect $\mathrm{N}_{2} \mathrm{O}$ and $\mathrm{CO}_{2}$ emissions from managed soils are presented in the IPCC guidelines for national greenhouse gas inventories (IPCC, 2006). -PPMS decomposition once applied on agricultural soils: - Factors reported to influence $\mathrm{N}_{2} \mathrm{O}$ emissions from land application of PPMS and organic fertilizers (Chantigny et al. 2013; Thangarajan et al., 2013):

- C:N ratio: PPMS application with high C: $\mathrm{N}$ ratio, such as de-inking PPMS, result in $\mathrm{N}$ immobilization which reduces $\mathrm{N}_{2} \mathrm{O}$ emissions.

- Denitrification/nitrification: $\mathrm{N}_{2} \mathrm{O}$ emissions are related to $\mathrm{NO}_{3}$ and $\mathrm{NH}_{4}$ availability.

- Labile carbon and organic matter contents.

- Estimation of $\mathrm{N}_{2} \mathrm{O}$ emissions from PPMS application on a fine-textured soil cropped with corn (Chantigny et al., 2013):

- Fertilizer-induced $\mathrm{N}_{2} \mathrm{O}$ emission factor (FIEF - i.e., percentage of applied nitrogen lost as $\mathrm{N}_{2} \mathrm{O}-\mathrm{N}$ emissions) for mixed PPMS: $0.9 \%$.

- FIEF for de-inking PPMS: $-0.4 \%$ (a negative value means that the application had lower $\mathrm{N}_{2} \mathrm{O}-\mathrm{N}$ emissions than the control). - Estimation of $\mathrm{N}_{2} \mathrm{O}$ emissions from mixed PPMS application on a fine-textured soil cropped with wheat (Faubert et al., 2015), FIEF: $1 \%$.

- Estimation of $\mathrm{N}_{2} \mathrm{O}$ emissions from PPMS application (type not determined in the study) on a soil (sandy loam) that had been cropped with calabrese, FIEF: 5\% (Baggs et al., 2002). - Default FIEF recommended by IPCC (2006) regardless of the fertilizer type (i.e., mineral vs. organic): $1 \%$.

- Direct $\mathrm{CH}_{4}$ emissions from agricultural soils are not significant (Ball et al., 2004; Jones et al., 2006).

-Determinants of indirect GHG emissions and offsets that should be considered in a life cycle analysis approach: - Fuel consumption resulting from PPMS handling: e.g., by transportation between the mill and the agricultural land and machinery used to apply PPMS on land.

- PPMS storage before application, if any: aerobic and anaerobic decomposition of organic matter releases GHG emissions (IPCC, 2006).

- GHG offsets:

- Soil carbon sequestration. BEAM uses an offset of $0.25 \mathrm{Mg}$ $\mathrm{CO}_{2}$ equivalent $\mathrm{Mg}^{-1}$ dry biosolid for land application of municipal biosolids (Brown et al., 2010). - Offsets from the substitution of mineral fertilizers by land application of organic fertilizers (Wood and Cowie, 2004; Murray et al., 2008; Brown et al., 2010).

Silviculture

-The study of Chuan-kuan et al. (2005) reported $\mathrm{CO}_{2}$ emissions from PPMS application from forest soil. The $\mathrm{CO}_{2}$ emission determinants were:

- Soil temperature

- Soil moisture only when it was below the critical value of $18 \%$ (10 cm depth)

- Possibly microbial respiration (not directly measured in the study) affected by PPMS labile carbon content combined with the low $\mathrm{C}: \mathrm{N}$ ratio and nitrogen addition

Land reclamation
-Literature reviewed did not provide information on determinants of GHG emissions from this practice concerning PPMS management.
-Future research should concentrate to unravel the impact of the agricultural management practices on the GHG emissions from land application of PPMS in agriculture.

-Information on GHG emissions from decomposition of PPMS applied on agricultural soils is scant. Future research should focus on increasing the knowledge on direct $\mathrm{N}_{2} \mathrm{O}$ emissions for each type of PPMS applied in order to increase the accuracy of the emission factors.

-All these factors should be included in life cycle analysis approaches. Future research should focus on measuring the GHG emissions from PPMS storage prior to land application, if any, as well as offsets for each type of PPMS applied.

-Upcoming research needs to determine the factors controlling direct and indirect GHG emissions from PPMS application on forest soils as literature on the topic does not actually provide substantial information.

-The review of Larney and Angers (2012) supports the need for further research that will unravel the factors controlling GHG emissions from this practice. 
Table 7 (Continued)

\begin{tabular}{|c|c|c|}
\hline $\begin{array}{l}\text { PPMS management } \\
\text { practice }\end{array}$ & Determinants of GHG emissions & $\begin{array}{l}\text { Upcoming research challenges leading to the assessments of } \\
\text { GHG emissions from the life cycles of PPMS management } \\
\text { practices }\end{array}$ \\
\hline
\end{tabular}

Composting prior to land application

$-\mathrm{CO}_{2}$ is the main GHG released from composting of organic matter, thus not included in a GHG inventory as it is from a biogenic source (IPCC, 2006). $\mathrm{N}_{2} \mathrm{O}$ emissions vary between less than $0.5-5 \%$ of the initial nitrogen content of the material and $\mathrm{CH}_{4}$ emissions range from less than $1 \%$ to a few percent of the initial carbon content in the material (IPCC, 2006). - Default emission factors presented by IPCC (2006) for waste composting:

- $\mathrm{CH}_{4}$ emissions: $10 \mathrm{~g} \mathrm{CH}_{4} \mathrm{~kg}^{-1}$ dry waste, uncertainty is $0.08-20 \mathrm{~g} \mathrm{CH}_{4} \mathrm{~kg}^{-1}$ dry waste.

- $\mathrm{N}_{2} \mathrm{O}$ emissions: $0.6 \mathrm{~g} \mathrm{~N}_{2} \mathrm{O} \mathrm{kg}^{-1}$ dry waste, uncertainty is $0.2-1.6 \mathrm{~g} \mathrm{~N}_{2} \mathrm{O} \mathrm{kg}^{-1}$ dry waste.

-No GHG emission factors were specifically found for PPMS composting.

PPMS energy recovery

Combustion

Anaerobic digestion
-Known determinants of $\mathrm{N}_{2} \mathrm{O}$ and $\mathrm{CH}_{4}$ emissions from biomass boilers:

- Combustion temperature:

- $\mathrm{N}_{2} \mathrm{O}$ emissions were determined to be the highest at $727^{\circ} \mathrm{C}$

(IEA GHG R\&D, 2000; Tsupari et al., 2007).

- Fuel characteristics:

- $\mathrm{N}_{2} \mathrm{O}$ and $\mathrm{CH}_{4}$ emission factors from different types of biomass (e.g., wood and wood waste) are presented in the calculation tool of NCASI (2005) and the IPCC guidelines for greenhouse gas inventories (IPCC, 2006), but no emission factors are estimated for PPMS

- $\mathrm{N}_{2} \mathrm{O}$ emissions may increase with nitrogen and char contents (Åmand and Leckner, 1991; Hämäläinen and Aho, 1996 Tsupari et al., 2007).

- Incomplete combustion increases $\mathrm{CH}_{4}$ emissions (Flagan and Seinfeld, 1988; Tsupari et al., 2007).

- $\mathrm{N}_{2} \mathrm{O}$ and $\mathrm{CH}_{4}$ emissions are often more directly associated to combustion conditions than to fuel type (NCASI, 2005): - Variability of $\mathrm{N}_{2} \mathrm{O}$ and $\mathrm{CH}_{4}$ emission factors are explained by types and ages of boilers and operating conditions (NCASI, 2005).

- GHG emissions $\left(\mathrm{N}_{2} \mathrm{O}\right.$ and $\left.\mathrm{CH}_{4}\right)$ of $0.00057-0.13 \mathrm{Mg} \mathrm{CO}$ equivalent $\mathrm{Mg}^{-1}$ dry mixed PPMS were measured from three types of biomass boilers; lowest emissions were from the fluidized bed boiler (Faubert et al., 2015).

-GHG offsets:

- Energy production from biomass may be a GHG emission offset compared with the use of fossil fuel.

$-\mathrm{CH}_{4}$ is the main $\mathrm{GHG}$ released from this process, which is induced by the anaerobic conditions (IPCC, 2006; Meyer and Edwards, 2014).

-Direct $\mathrm{CH}_{4}$ emissions from gas collection systems are judged negligible when it is burned and converted to $\mathrm{CO}_{2}$, as it is from biogenic sources (NCASI, 2005).

$-\mathrm{CH}_{4}$ leakage from collection systems may occur and represent up to $10 \%$ of the total amount of $\mathrm{CH}_{4}$ generated (IPCC, 2006). Specific information on $\mathrm{CH}_{4}$ leakage from gas collection systems for anaerobic digestion of PPMS is not available. -Meyer and Edwards (2014) reported that $\mathrm{CH}_{4}$ emissions or yields from anaerobic digestion of PPMS depend on:

- Chemical oxygen demand

- Volatile solid fed

- Pretreatment, if any. Highest $\mathrm{CH}_{4}$ yields were reported with thermal pretreatment, microwave pretreatment and high-pressure homogenization.

- PPMS type and properties

-The review of Meyer and Edwards (2014) reported $\mathrm{CH}_{4}$ yields varying between $40-200 \mathrm{ml} \mathrm{g}^{-1}$ volatile solid fed for various types of PPMS.
-GHG emission factors need to be assessed for PPMS composting.

-Estimations of GHG emissions from municipal biosolids revealed large uncertainties (Bhunia et al., 2010). Research on GHG emissions from PPMS composting need to be initiated if this practice is to be applied as an alternative to landfilling.

-This critical value should be validated with measurements as it may depend on operating conditions (NCASI, 2005).

-Data on GHG emissions from biomass combustion are scant (NCASI, 2005). PPMS contribution to GHG emissions within a fuel mixture should be isolated. As emissions vary with combustion and operating conditions responsible for large uncertainties (IPCC, 2006), it would be appropriate that a mill measures its own GHG emission factors instead of using default values (NCASI, 2005; Faubert et al., 2015). Such factors should be estimated for each type of PPMS

-The offsets should be identified, measured and integrated in a life cycle analysis approach.

$-\mathrm{CH}_{4}$ emissions should be included in a GHG inventory when the gas is collected and directly released to the atmosphere, without being burned and converted to $\mathrm{CO}_{2}$ (NCASI, 2005. IPCC, 2006)

$-\mathrm{CH}_{4}$ emissions should be included in a GHG inventory only if a substantial gas leakage occurs from the system (NCASI, 2005; IPCC, 2006)

-Meyer and Edwards (2014) suggested that future research should focus on these factors to increase $\mathrm{CH}_{4}$ emission yields from anaerobic digestion of PPMS. 
Table 7 (Continued)

\begin{tabular}{|c|c|c|}
\hline $\begin{array}{l}\text { PPMS management } \\
\text { practice }\end{array}$ & Determinants of GHG emissions & $\begin{array}{l}\text { Upcoming research challenges leading to the assessments of } \\
\text { GHG emissions from the life cycles of PPMS management } \\
\text { practices }\end{array}$ \\
\hline
\end{tabular}

$-\mathrm{N}_{2} \mathrm{O}$ emissions from anaerobic digestion of organic matter were judged negligible (NCASI, 2005; IPCC, 2006) and not reported in the review of Meyer and Edwards (2014) for PPMS. -GHG offsets:

- $\mathrm{CH}_{4}$ produced by anaerobic digestion of PPMS is usually collected and burned to produce steam and electricity (Meyer and Edwards, 2014).

- Digestate can be used as a fertilizer (Meyer and Edwards, 2014).

Pyrolysis

-This is a net energy positive process and not known to be a net GHG emission source as it sustains itself once it is initiated (Laird et al., 2009; Miller-Robbie et al., 2015).

-GHG emissions are related to energy required for biomass handling (e.g., harvest and transport) and to build the pyrolysis equipment and plant as well as for its maintenance (Laird et al., 2009).

-GHG offsets:

- Bio-oil and gases are used as fuel (Laird et al., 2009; Lou et al.,

2012; Ouadi et al., 2013; Miller-Robbie et al., 2015) that can

substitute fossil fuel.

- Biochar contributes to carbon sequestration (McGlashan

et al., 2012; McLaren, 2012; Thornley et al., 2015).

Bioethanol production and other energy recovery practices

-Literature reviewed on these practices did not provide

information on determinants of GHG emissions.
-These offsets should be measured and integrated in a life cycle analysis approach.
-Miller-Robbie et al. (2015) presented one of the first life cycle analyses of the co-location of a pyrolysis plant with a municipal wastewater treatment plant. GHG emissions were evaluated in scenarios comparing pyrolysis with common municipal biosolid management (landfilling, incineration and land application). Such life cycle analyses should also be performed for PPMS to assess the net effect of pyrolysis on the GHG emissions.

Integration of PPMS in materials: biocomposites (wood and plastic materials), cement, asphalt and adsorbent-absorbent

-Determinants of GHG emissions from these practices were not presented in the literature reviewed.

-A life cycle analysis was performed and compared the carbon footprints of the combinations of these scenarios in which de-inking PPMS is used as sorbent (Likon and Saarela, 2012; Likon and Trebše, 2012):

- Substitution of expanded polypropylene with PPMS as sorbent for oil spill sanitation

- PPMS used as sorbent instead of disposal by landfilling

-The lack of information on these practices supports the need for future research that would characterize the GHG emissions and offsets (e.g., fossil fuel substitution).

\footnotetext{
-Deviatkin et al. (2015) also reported the results of a life cycle analysis in which the global warming potentials of baseline and alternative scenarios were compared for de-inking PPMS - Baseline scenario: landfilling disposal

- Four alternative scenarios in which PPMS is used in two cement plants, a lightweight aggregate plant and stone wool plant.
}

scenarios in which landfilling is included (Brown et al., 2008; Pikon and Gaska, 2010). On the other hand, a review underlined that composting of municipal biosolids can produce significant $\mathrm{N}_{2} \mathrm{O}$ emissions that may be greater than demonstrated by the actual studies (Bhunia et al., 2010). More research is obviously needed to determine whether composting PPMS before land application reduces or produces similar GHG emissions as landfilling (Table 7).

The technologies on the use of PPMS in energy recovery practices have the potential to offset GHG emissions as it substitutes the consumption of fossil fuel to produce heat (Table 7; CANMET, 2005). Several compounds are produced following biomass combustion for energy recovery. Emissions of atmospheric contaminants must be monitored on a regular basis, as it is required by laws and regulations in several countries. However, little data exist on the contribution of PPMS combustion on the GHG emission budgets from boiler and recovery furnaces (Gavrilescu, 2008). Emission of $\mathrm{CO}_{2}$ from PPMS combustion is usually excluded from GHG inventories as it is from biogenic sources (IPCC, 2006). Emissions of $\mathrm{N}_{2} \mathrm{O}$ and $\mathrm{CH}_{4}$ are important GHGs produced by PPMS combustion and should be included in GHG emission inventories. $\mathrm{N}_{2} \mathrm{O}$ emissions depend on combustion temperature and fuel type (Tsupari et al., 2007), they were determined to be the highest at a temperature of $727^{\circ} \mathrm{C}$ and negligible at temperatures below $527^{\circ} \mathrm{C}$ or above $927^{\circ} \mathrm{C}$ (IEA GHG R\&D, 2000). $\mathrm{N}_{2} \mathrm{O}$ emissions may increase with the nitrogen and char contents in the fuel during combustion (Åmand and Leckner, 1991; Hämäläinen and Aho, 1996; Tsupari et al., 2007). $\mathrm{CH}_{4}$ emissions from boilers and furnaces arise when combustion is incomplete and when oxidation reactions are quenched at the beginning of the combustion (Flagan and Seinfeld, 1988; Tsupari et al., 2007). Large boilers with efficient combustion rarely emit $\mathrm{CH}_{4}$ compared to small scale combustion, heating stoves and open fireplaces (IPCC, 2006; Tsupari et al., 2007). $\mathrm{N}_{2} \mathrm{O}$ and $\mathrm{CH}_{4}$ emissions from biomass boilers and recovery furnaces from pulp and paper production are scarcely known and uncertainties are still 
rather large (IPCC, 2006). The IPCC (2006) estimated the uncertainties for $\mathrm{N}_{2} \mathrm{O}$ and $\mathrm{CH}_{4}$ emission factors for stationary combustion to be of one order of magnitude and \pm 50 to $150 \%$, respectively. The calculation tool built by NCASI (2005) estimates $\mathrm{N}_{2} \mathrm{O}$ and $\mathrm{CH}_{4}$ emissions from biomass combustion practiced in pulp and paper industry but no emission factors are available yet for PPMS combustion. Therefore, further research should be conducted to decrease the large uncertainties and lack of emission factors in order to estimate and isolate the contribution of PPMS combustion on GHG emission budgets from pulp and paper industry (Table 7).

The main GHG emitted from anaerobic digestion of PPMS is $\mathrm{CH}_{4}$, which yields vary between 40 and $200 \mathrm{ml} \mathrm{g}^{-1}$ volatile solid fed for various types of PPMS (Table 7; Meyer and Edwards, 2014). $\mathrm{CH}_{4}$ yields depend on the factors presented in Table 7 as reviewed by Meyer and Edwards (2014). The technologies increasing the efficiency of biogas production from PPMS in bioreactors could lead to GHG offsets. Such biogas production reduces electricity consumption and PPMS production (Magnusson and Alvfors, 2012). Anaerobic digestion of municipal biosolids was shown to decrease GHG emissions compared to combustion (Zitomer et al., 2008; Ashrafi et al., 2015). Fossil fuel can also be replaced by biogas, thereby potentially reducing GHG emissions, the impacts on the environment and climate change (Poeschl et al., 2012). Digestates from biogas production can be substitutes for mineral fertilizers applied on agricultural land, again reducing GHG emissions (IPCC, 2006; Murray et al., 2008; Wood et al., 2009; Brown et al., 2010; Poeschl et al., 2012; Meyer and Edwards, 2014; Dahlin et al., 2015). Modeling and simulations can estimate $\mathrm{CH}_{4}$ emissions from PPMS anaerobic digestion in the wastewater treatment plants of pulp and paper mills (Ashrafi et al., 2013a, 2013b, 2015; O'Connor et al., 2014). Hence, research on the assessments of GHG emissions is advanced and this practice could be included in future PPMS management practices as an alternative to landfilling but the GHG emissions need to be compared to diverse landfilling current scenarios.

PPMS pyrolysis produces liquid fuel, gases and biochar that come from biomass, a renewable source. Life cycle analyses are needed to quantify the effective impact of PPMS pyrolysis on the GHG emission reduction among other impacts (Table 7). The solid residue produced by pyrolysis, the biochar, can be applied on agricultural soils as an amendment in combination with mineral and organic fertilizers to improve soil properties (Camps Arbestain et al., 2014). Biochar also stocks carbon in soils and has the potential to reduce their GHG emissions, but more research is needed on the actual mechanisms (Lehmann, 2007; Cayuela et al., 2013, 2014). Miller-Robbie et al. (2015) performed a life cycle analysis evaluating the potential of GHG emission reduction for the co-production of biochar (from yard trimmings feedstock) and municipal biosolids (Table 7). When compared to the current US biosolid disposal practice (55\% land applied without biochar, 30\% landfilled, $15 \%$ incinerated), a GHG emission reduction of $26 \%$ was achieved when $55 \%$ of the biosolids were combined with biochar and land applied (Miller-Robbie et al., 2015). Biochar is a form of negative emission technology, which is defined as a mean to withdraw GHGs from the atmosphere (McGlashan et al., 2012; McLaren, 2012; Thornley et al., 2015). Thus, biochar production is a technology with real potential for atmospheric $\mathrm{CO}_{2}$ reduction, receiving research attention from substantial levels of academic or privately funded research, but it seems unlikely that large scale productions would be deployed before the 2020s or 2030s (McLaren, 2012). Determinants of GHG emissions were not reported from the literature reviewed on the production of bioethanol and biohydrogen (fermentation and supercritical water treatments) from PPMS as well as biofuel production from direct liquefaction, opening several new research opportunities (Table 7).
All the options aiming at using PPMS in a variety of materials provide a longer GHG storage period compared with landfilling, which is beneficial to the carbon debt in proportions to the material lifetime (Tables 6 and 7). Life cycle analyses comparing the GHG emissions from various uses of PPMS in materials show the potential for emission reductions when compared to the baseline scenario of landfilling (Likon and Saarela, 2012; Likon and Trebše, 2012; Deviatkin et al., 2015). Utilization of PPMS for its sorptive property could be a practice that extends its life cycle before being definitely disposed of. Using databases, a life cycle analysis was performed to compare the carbon footprints between the uses of de-inking PPMS (defined as "unwanted by-product in paper and cardboard recycling processes") versus expanded polypropylene as sorbents for oil spill sanitation and/or de-inking PPMS disposal by landfilling (Likon and Saarela, 2012; Likon and Trebše, 2012). Results showed that the carbon footprint was decreased by 2.75 times if de-inking PPMS was used as a sorbent for oil spill sanitation instead of expanded polypropylene and by 5.25 times compared to sending it straight to a landfill site (Likon and Saarela, 2012; Likon and Trebše, 2012). Once the options of using de-inking PPMS as a sorbent instead of expanded polypropylene and landfill disposal were combined, the carbon footprint was reduced by more than 14 times (Likon and Saarela, 2012; Likon and Trebše, 2012). Contaminated de-inking PPMS used as a sorbent was assumed to be ultimately disposed of by combustion for energy recovery (Likon and Saarela, 2012; Likon and Trebše, 2012). The GHG emission factor for landfilling was not based from measurements on an actual landfill site but from an equation for aerobic and anaerobic decay (Table 7; Buswell and Mueller, 1952; Likon and Saarela, 2012; Likon and Trebše, 2012). Nevertheless, this modeling exercise tended to demonstrate that using de-inking PPMS as a sorbent could decrease the impact on climate change when the disposal practice is diverged from landfilling.

Using modeling and databases in a life cycle analysis on deinking PPMS management, Deviatkin et al. (2015) compared the global warming potentials of the landfilling baseline scenario with alternative scenarios in which PPMS was integrated in cement, lightweight aggregate and stone wool (Table 7). GHG emission factors used for PPMS landfilling were from the landfilling of municipal solids and industrial wastes (Deviatkin et al., 2015), which demonstrates that factors specific for PPMS are crucially needed as such life cycle analyses may become more common. The results showed that using PPMS in cement production (substituting limestone and petcoke) reduced the global warming potential by $13 \%$ (Deviatkin et al., 2015). The authors concluded that utilization of de-inking PPMS in the scenarios tested instead of landfilling can improve environmental quality and support waste paper recycling as a part of circular economy and cleaner production (Deviatkin et al., 2015). Thus, such analyses (Likon and Saarela, 2012; Likon and Trebše, 2012; Deviatkin et al., 2015) should be performed to tend toward a responsible PPMS management. Life cycle analyses based on field measurements are needed to assess the carbon footprints of using PPMS in materials to compare with current scenarios. Most of the literature reviewed and presented in Section 5 did not mention how PPMS was disposed of after being used in materials. Therefore, GHG emissions from the ultimate PPMS disposal should also be documented depending on the management practice.

\section{Conclusions and recommendations}

This review demonstrated that there are numerous PPMS management practices and alternative options to disposal by landfilling, which tends to be reduced or banned in certain jurisdictions (Council of the European Communities, 1991; US EPA, 1994; Ljunggren Söderman, 2003; EC-BiPRO, 2007; Fytili and Zabaniotou, 
2008; Monte et al., 2009; MfE, 2010; MDDEP, 2011; Gouvernement du Québec, 2012). PPMS land application in agriculture and energy recovery through combustion actually are the most practiced alternatives to disposal by landfilling. However, these may not be applicable for the entire volume of PPMS generated by all pulp and paper mills once/if landfilling is banned. It is therefore imperative to find different usages. This review showed that emerging practices have great potential to recycle and valorize PPMS by creating industrial synergies in which the residual of one industry can be used as a resource by another industry.

As mentioned, GHG emissions from the actual PPMS management are unknown for the current scenarios in which disposal by landfilling is still allowed and practiced. These emissions need to be assessed in order to plan responsible future PPMS management practices that will effectively decrease GHG emissions. The key to estimate GHG emissions from all the possible scenarios is the life cycle analysis. Modeling approaches can estimate GHG emissions from wastewater treatment plants (Ashrafi et al., 2013b, 2013a, 2015; O'Connor et al., 2014; Zang et al., 2015) but the emissions are unknown outside the mill operations. In Canada, GHG emissions from municipal biosolid management can be assessed by BEAM (SYLVIS, 2009; Brown et al., 2010). A similar modeling approach would be more than helpful for PPMS management. However, field measurements on the GHG emissions from the actual and emerging PPMS management practices are missing to feed life cycle analysis models. Such GHG emission data could be integrated in widely used databases such as Ecoinvent (2013) and life cycle analysis models would ultimately lead to approved GHG emission protocols to foster better management practices through the local and global carbon markets. For instance in the province of Quebec, Canada, such life cycle analyses would be essential to support the objectives of the 2013-2020 climate change action plan aiming at reducing GHG emissions of $20 \%$ below the 1990 level by 2020 (Gouvernement du Québec, 2012).

PPMS management practices identified in this review lead to the following recommendations on the next research issues in terms of GHG emission quantification:

\section{(1) PPMS landfilling}

Future research should focus on measuring the GHG emissions from landfill sites in which PPMS is disposed of, in order to correctly assess the current management scenarios. As pulp and paper mill landfill sites contain other residues than PPMS, future research should also isolate the PPMS contribution to the emissions. These GHG emission data will be essential in planning future responsible management practices.

(2) PPMS land application

Future research should focus on measuring the actual GHG emissions from PPMS decomposition after being applied as a soil amendment in agriculture as it has been done for other kinds of organic amendments, such as municipal biosolids and manures. The impact of driving factors such as soil type, crop, application season and climate need to be better related to the $\mathrm{N}_{2} \mathrm{O}$ emission dynamics of applied PPMS on agricultural soils. Similarly, data on GHG emissions from PPMS used in silviculture, land reclamation and composting need to be acquired.

(3) PPMS energy recovery

Future research should aim at isolating the GHG emission contribution of PPMS within the fuel mixture when combustion is practiced. The NCASI GHG calculation tool (NCASI, 2005) actually assesses the GHG emissions from biomass boilers but GHG emission fraction from PPMS combustion is not isolated, which should be addressed. Studies on the GHG emissions from the emerging practices of anaerobic digestion, pyrolysis, bioethanol and hydrogen productions as well as direct liquefaction are also needed. Emissions need to be measured or estimated by life cycle analyses for each PPMS treatment according to the relating practice. These emission assessments are essential if to be compared with landfilling practices in order to determine if GHG emissions are avoided and/or decreased when considering the whole processes.

(4) PPMS integration in materials

PPMS integration in materials could be interpreted as a practice that delays the disposal by landfilling, as all materials are ultimately disposed of after a certain period of time. Thus, future research should use life cycle analyses to assess if GHG emissions of PPMS stored in various materials are lower than direct landfill disposal or other management practices. GHG emission assessment from PPMS integration in materials is important as it can lead to industrial synergies, which have economic and environmental benefits.

As research progresses and GHG data related to the different PPMS management practices are obtained, models will gain in accuracy and will contribute to assist decision makers in implementing the best PPMS management practices i.e., those with the least impact on climate change.

\section{Acknowledgments}

This study was funded by the Ministère du Développement durable, de l'Environnement et de la Lutte contre les changements climatiques of Québec. We are also grateful for the collaborative support from the Québec Forest Industry Council.

\section{References}

Ackermann, R., Hughes, G., Hanrahan, D., Somani, A., Aggarwal, S., Fitzgerald, A., Dixon, J., Kunte, A., Lovei, M., Lvovsky, K., 1999. Pollution Prevention and Abatement Handbook 1998: Toward Cleaner Production. World Bank Group, Washington, DC, USA, pp. 471.

Ahmadi, B., Al-Khaja, W., 2001. Utilization of paper waste sludge in the building construction industry. Resour. Conserv. Recycl. 32 (2), 624824, 105-113, http://dx.doi.org/10.1016/S0921-3449(01)00051-9.

Aitken, M.N., Evans, B., Lewis, J.G., 1998. Effect of applying paper mill sludge to arable land on soil fertility and crop yields. Soil Use Manag. 14 (4), 215-222 http://dx.doi.org/10.1111/j.1475-2743.1998.tb00153.x.

Allahdadi, I., Beauchamp, C.J., Chalifour, F.-P., 2004. Symbiotic dinitrogen fixation in forage legumes amended with high rates of de-inking paper sludge. Agron. J. 96 (4), 956-965, http://dx.doi.org/10.2134/agronj2004.0956.

Almquist, C., Qin, N., 2013. Pyrolysis of deinked paper sludge to synthesize adsorbents for elemental $\mathrm{Hg}$ vapors. Environ. Prog. Sustain. Energy 32 (3), 524-534, http://dx.doi.org/10.1002/ep.11652.

Åmand, L.E., Leckner, B., 1991. Oxidation of volatile nitrogen compounds during combustion in circulating fluidized bed boilers. Energy Fuels 5 (6), 809-815, http://dx.doi.org/10.1021/ef00030a007.

Amberg, H.R., 1984. Sludge dewatering and disposal in the pulp and paper industry. Journal (Water Pollut. Control Federation) 56 (8), 962-969, http://dx. doi.org/10.2307/25042402.

Amini, S., Movahedi Naeini, S.A.R., Mashayekhi, K., 2012. Effects of paper-mill sludge as a mulch versus topsoil incorporation on potassium uptake and the grain yield of rain-fed wheat in a high specific surface loess soil with illite dominance in clay fraction. Appl. Environ. Soil Sci., 2012, http://dx.doi.org/10. $1155 / 2012 / 624824$

Amoo, L.M., Fagbenle, R.L., 2014. An integrated impact assessment of hydrogen as a future energy carrier in Nigeria's transportation, energy and power sectors. Int. J. Hydrogen Energy 39 (24), 1732, 12409-12433, http://dx.doi.org/10.1016/j. ijhydene.2014.06.022.

Ashrafi, O., Yerushalmi, L., Haghighat, F., 2013a. Application of dynamic models to estimate greenhouse gas emission by wastewater treatment plants of the pulp and paper industry. Environ. Sci. Pollut. Res. 20 (3), 1858-1869, http://dx.doi. org/10.1007/s11356-012-1310-5.

Ashrafi, O., Yerushalmi, L., Haghighat, F., 2013b. Greenhouse gas emission by wastewater treatment plants of the pulp and paper industry - modeling and simulation. Int. J. Greenh. Gas Control 17, 462-472, http://dx.doi.org/10.1016/j. ijggc.2013.06.006.

Ashrafi, O., Yerushalmi, L., Haghighat, F., 2015. Wastewater treatment in the pulp-and-paper industry: a review of treatment processes and the associated greenhouse gas emission. J. Environ. Manag. 158, 146-157, http://dx.doi.org/ 10.1016/j.jenvman.2015.05.010. 
Baeyens, J., Kang, Q., Appels, L., Dewil, R., Lv, Y., Tan, T., 2015. Challenges and opportunities in improving the production of bio-ethanol. Prog. Energy Combust. Sci. 47, 60-88, http://dx.doi.org/10.1016/j.pecs.2014.10.003.

Baggs, E.M., Rees, R.M., Castle, K., Scott, A., Smith, K.A., Vinten, A.J.A., 2002. Nitrous oxide release from soils receiving $\mathrm{N}$-rich crop residues and paper mill sludge in eastern Scotland. Agric. Ecosyst. Environ. 90 (2), 109-123, http://dx.doi.org/10. 1016/s0167-8809(01)00175-X.

Ball, B.C., McTaggart, I.P., Scott, A., 2004. Mitigation of greenhouse gas emissions from soil under silage production by use of organic manures or slow-release fertilizer. Soil Use Manag. 20 (3), 287-295, http://dx.doi.org/10.1111/j.14752743.2004.tb00371.x.

Baziramakenga, R., Simard, R.R., 2001. Effect of deinking paper sludge compost on nutrient uptake and yields of snap bean and potatoes grown in rotation. Compost Sci. Util. 9 (2), 115-126, http://dx.doi.org/10.1080/1065657X.2001. 10702025.

Beauchamp, C.J., Boulanger, R., Matte, J., Saint-Laurent, G., 2002. Examination of the contaminants and performance of animals fed and bedded using de-inking paper sludge. Arch. Environ. Contam. Toxicol. 42 (4), 523-528, http://dx.doi. org/10.1007/s00244-001-0036-Z.

Behrendt, F., Neubauer, Y., Oevermann, M., Wilmes, B., Zobel, N., 2008. Direct liquefaction of biomass. Chem. Eng. Technol. 31 (5), 667-677, http://dx.doi. org/10.1002/ceat.200800077.

Bhunia, P., Yan, S., LeBlanc, R.J., Tyagi, R.D., Surampalli, R.Y., Zhang, T.C., 2010. Insight into nitrous oxide emissions from biological wastewater treatment and biosolids disposal. Pract. Period. Hazard. Toxic Radioact. Waste Manag. 14 (3), 158-169, http://dx.doi.org/10.1061/(ASCE)HZ.1944-8376.0000029.

Bouwman, A.F., 1996. Direct emission of nitrous oxide from agricultural soils. Nutr Cycl. Agroecosyst. 46 (1), 53-70, http://dx.doi.org/10.1007/bf00210224.

Bouwman, A.F., 1998. Environmental science: nitrogen oxides and tropical agriculture. Nature 392 (6679), 866-867, http://dx.doi.org/10.1038/31809.

Brown, S., Beecher, N., Carpenter, A., 2010. Calculator tool for determining greenhouse gas emissions for biosolids processing and end use. Environ. Sci. Technol. 44 (24), 9509-9515, http://dx.doi.org/10.1021/es101210k.

Brown, S., Kruger, C., Subler, S., 2008. Greenhouse gas balance for composting operations. J. Environ. Qual. 37 (4), 1396-1410, http://dx.doi.org/10.2134 jeq2007.0453.

Buruberri, L.H., Seabra, M.P., Labrincha, J.A., 2015. Preparation of clinker from paper pulp industry wastes. J. Hazard. Mater. 286, 252-260, http://dx.doi.org/ 10.1016/j.jhazmat.2014.12.053.

Buswell, A.M., Mueller, H.F., 1952. Mechanism of methane fermentation. Ind. Eng. Chem. 44 (3), 550-552, http://dx.doi.org/10.1021/ie50507a033.

Cabral, F., Vasconcelos, E., Goss, M.J., Cordovil, C.M., 1998. The value, use, and environmental impacts of pulp-mill sludge additions to forest and agricultura lands in Europe. Environ. Rev. 6 (1), 55-64, http://dx.doi.org/10.1139/a98-004.

Calace, N., Di Muro, A., Nardi, E., Petronio, B.M., Pietroletti, M., 2002. Adsorption isotherms for describing heavy-metal retention in paper mill sludges. Ind. Eng Chem. Res. 41 (22), 5491-5497, http://dx.doi.org/10.1021/ie011029u.

Calace, N., Nardi, E., Petronio, B.M., Pietroletti, M., Tosti, G., 2003. Metal ion removal from water by sorption on paper mill sludge. Chemosphere 51 (8), 797-803, http://dx.doi.org/10.1016/S0045-6535(02)00864-0.

Camberato, J.J., Gagnon, B., Angers, D.A., Chantigny, M.H., Pan, W.L., 2006. Pulp and paper mill by-products as soil amendments and plant nutrient sources. Can. J. Soil Sci. 86 (4), 641-653, http://dx. doi.org/10.4141/S05-120.

Camberato, J.J., Vance, E.D., Someshwar, A.V., 1997. In: Rechcigl, J.E., MacKinnon, H.C. (Eds.), Agricultural Uses of By-products and Wastes. American Chemical Society, pp. 185-202, http://dx.doi.org/10.1021/bk-1997-0668.ch012.

Camps Arbestain, M., Saggar, S., Leifeld, J., 2014. Environmental benefits and risks of biochar application to soil. Agric. Ecosyst. Environ. 191, 1-4, http://dx.doi. org/10.1016/j.agee.2014.04.014.

CANMET E.T.C., 2005. Pulp and Paper Sludge to Energy - Preliminary Assessment of Technologies. Natural Resources Canada, CANMET Energy. Report (34) 0173e479.1., pp. 152

Carlsson, M., Lagerkvist, A., Morgan-Sagastume, F., 2012. The effects of substrate pre-treatment on anaerobic digestion systems: a review. Waste Manag. 32 (9), 1634-1650, http://dx.doi.org/10.1016/j.wasman.2012.04.016.

Caulfield, P., 2012. Unlocking the value in sludge. Pulp Pap. Can. 113, 18-19.

Cayuela, M.L., Sánchez-Monedero, M.A., Roig, A., Hanley, K., Enders, A., Lehmann, J, 2013. Biochar and denitrification in soils: when, how much and why does biochar reduce $\mathrm{N}_{2} \mathrm{O}$ emissions? Sci. Rep. 3, http://dx.doi.org/10.1038/ srep01732.

Cayuela, M.L., van Zwieten, L., Singh, B.P., Jeffery, S., Roig, A., Sánchez-Monedero, M.A., 2014. Biochar's role in mitigating soil nitrous oxide emissions: a review and meta-analysis. Agric. Ecosyst. Environ. 191, 5-16, http://dx.doi.org/10. 1016/j.agee.2013.10.009.

Chantigny, M.H., Angers, D.A., Beauchamp, C.J., 1999. Aggregation and organic matter decomposition in soils amended with de-inking paper sludge. Soil Sci. Soc. Am. J. 63 (5), 1214-1221, http://dx.doi.org/10.2136/sssaj1999.6351214x.

Chantigny, M.H., Angers, D.A., Beauchamp, C.J., 2000. Active carbon pools and enzyme activities in soils amended with de-inking paper sludge. Can. J. Soil Sci. 80 (1), 99-105, http://dx.doi.org/10.4141/S99-050.

Chantigny, M.H., Pelster, D.E., Perron, M.-H., Rochette, P., Angers, D.A., Parent, L.-É. Massé, D., Ziadi, N., 2013. Nitrous oxide emissions from clayey soils amended with paper sludges and biosolids of separated pig slurry. J. Environ. Qual. 42 (1), 30-39, http://dx.doi.org/10.2134/jeq2012.0196.

Charbonneau, H., Hébert, M., Jaouich, A., 2001. Translation of the original title in French: Portrait de la valorisation agricole des matières résiduelles fertilisantes au Québec-partie 2: Contenu en éléments fertilisants et qualité environnementale (Overview of the agricultural valorization of the fertilizing residual matter in Quebec - Part 2: Content in fertilizing elements and environmental quality). Vecteur Environ. 34 (1), 56-60.

Charest, M.H., Antoun, H., Beauchamp, C.J., 2004. Dynamics of water-soluble carbon substances and microbial populations during the composting of de-inking paper sludge. Bioresour. Technol. 91 (1), 53-67, http://dx.doi.org/10. 1016/S0960-8524(03)00155-X.

Charest, M.H., Beauchamp, C.J., 2002. Composting of de-inking paper sludge with poultry manure at three nitrogen levels using mechanical turning: behavior of physico-chemical parameters. Bioresour. Technol. 81 (1), 7-17, http://dx.doi. org/10.1016/S0960-8524(01)00104-3.

Chuan-kuan, W., Feldkirchner, D., Gower, S., Ferris, J., Kruger, E., 2005. Effects of amendments of paper mill sludge and nutrients on soil surface $\mathrm{CO}_{2}$ flux in northern hardwood forests. J. For. Res. 16 (4), 265-269, http://dx.doi.org/10. $1007 / B F 02858186$.

Council of the European Communities (The), 1991. Council directive 91/271/EEC of 21 march 1991 concerning urban waste-water treatment. The Council of the European Communities, Official Journal of the European Communities, Rule OJ L 135, 30.5.1991

Crain, N., Shanableh, A., Gloyna, E., 2000. Supercritical water oxidation of sludges contaminated with toxic organic chemicals. Water Sci. Technol. 42 (7-8), 363-368.

Curnoe, W.E., Irving, D.C., Dow, C.B., Velema, G., Unc, A., 2006. Effect of spring application of a paper mill soil conditioner on corn yield. Agron. J. 98 (3) 423-429, http://dx.doi.org/10.2134/agronj2005.0041.

Dahlin, J., Herbes, C., Nelles, M., 2015. Biogas digestate marketing: qualitative insights into the supply side. Resour. Conserv. Recycl. 104 (Part A), 152-161, http://dx.doi.org/10.1016/j.resconrec.2015.08.013.

Davis, E., Shaler, S.M., Goodell, B., 2003. The incorporation of paper deinking sludge into fiberboard. For. Prod. J. 53 (11/12), 46-54.

Demir, I., Serhat Baspınar, M., Orhan, M., 2005. Utilization of kraft pulp production residues in clay brick production. Build. Environ. 40 (11), 1533-1537, http:// dx.doi.org/10.1016/j.buildenv.2004.11.021.

Demirbas, M.F., Balat, M., Balat, H., 2011. Biowastes-to-biofuels. Energy Conv. Manag. 52 (4), 1815-1828, http://dx.doi.org/10.1016/j.enconman.2010.10.041.

Deviatkin, I., Kapustina, V., Elena, V., Isyanov, L., Horttanainen, M., 2015. Comparative life cycle assessment of deinking sludge utilization alternatives. J. Clean. Prod., http://dx.doi.org/10.1016/j.jclepro.2015.10.022 (in press).

Dolar, S.G., Boyle, J.R., Keeney, D.R., 1972. Paper mill sludge disposal on soils: effects on the yield and mineral nutrition of oats (Avena sativa L.). J. Environ. Qual. 1 (4), 405-409, http://dx.doi.org/10.2134/jeq1972.00472425000100040015x.

EC-BiPRO (European Commission-Beratungsgesellschaft für integrierte Problemlösungen), 2007. Organisation of Awareness-raising Events Concerning the Implementation of Directive 1999/31 EC on the Landfill of Waste. Reference: Env.G.4/ser/2006/0049. European Commission, Brussels, Belgium, pp. 133

Ecoinvent, 2013. Swiss Centre for Life Cycle Inventories. Ecoinvent Database Version 3.1. Ecoinvent Centre, Zürich, Switzerland.

Eifling, B.R., Ebbers, J.H., 2006. Cellulose absorbent. Patent number: US 7,038,104 B1. USA.

Elliott, A., Mahmood, T., 2005. Survey benchmarks generation, management of solid residues. Pulp Pap. 79 (12), 49-55.

Elliott, A., Mahmood, T., 2007. Pretreatment technologies for advancing anaerobic digestion of pulp and paper biotreatment residues. Water Res. 41 (19), 4273-4286, http://dx.doi.org/10.1016/j.watres.2007.06.017.

Elliott, A., Mahmood, T., 2012. Comparison of mechanical pretreatment methods for the enhancement of anaerobic digestion of pulp and paper waste activated sludge. Water Environ. Res. 84 (6), 497-505, http://dx.doi.org/10.2175/ $106143012(13347678384602$

Elvira, C., Sampedro, L., Benítez, E., Nogales, R., 1998. Vermicomposting of sludges from paper mill and dairy industries with Eisenia Andrei: a pilot-scale study. Bioresour. Technol. 63 (3), 205-211, http://dx.doi.org/10.1016/S09608524(97)00145-4.

Environment Canada, 2015. National Inventory Report 1990-2013. Greenhouse Gas Sources and Sinks in Canada. The Canadian Government's Submission to the UN Framework Convention on Climate Change. Part 1, Environment Canada, Gatineau, QC, Canada., pp. 208

Fan, J.-L., Ziadi, N., Gagnon, B., Hu, Z.-Y., 2010. Soil phosphorus fractions following annual paper mill biosolids and liming materials application. Can. J. Soil Sci. 90 (3), 467-479, http://dx.doi.org/10.4141/CJSS09037.

Fan, Z., Lynd, L.R., 2007a. Conversion of paper sludge to ethanol. II: Process design and economic analysis. Bioprocess Biosyst. Eng. 30 (1), 35-45, http://dx.doi. org/10.1007/s00449-006-0092-x.

Fan, Z., Lynd, L.R., 2007b. Conversion of paper sludge to ethanol. I: Impact of feeding frequency and mixing energy characterization. Bioprocess Biosyst. Eng. 30 (1), 27-34, http://dx.doi.org/10.1007/s00449-006-0091-y.

Fan, Z., South, C., Lyford, K., Munsie, J., van Walsum, P., Lynd, L.R., 2003. Conversion of paper sludge to ethanol in a semicontinuous solids-fed reactor. Bioprocess Biosyst. Eng. 26 (2), 93-101, http://dx.doi.org/10.1007/s00449-003-0337-x.

FAOSTAT (Food and Agriculture Organization of the United Nations - Statistics Division), 2015. Domain Forestry, http://faostat3.fao.org/download/F/FO/E (accessed 15.06.15)

Fargione, J., Hill, J., Tilman, D., Polasky, S., Hawthorne, P., 2008. Land clearing and the biofuel carbon debt. Science 319 (5867), 1235-1238, http://dx.doi.org/10. 1126/science. 1152747. 
Faubert, P., Lemay-Bélisle, C., Bertrand, N., Bouchard, S., Chantigny, M., Durocher, S., Rochette, P., Tremblay, P., Ziadi, N., Villeneuve, C., 2015. La gestion des biosolides de papetières au Québec: quelle serait la meilleure option pour réduire les émissions de gaz à effet de serre? (Pulp and paper mill sludge management in Quebec: what should be the best option to reduce greenhouse gas emissions?). Vecteur Environ. 48 (5), 50-58.

Feagley, S.E., Valdez, M.S., Hudnall, W.H., 1994. Bleached, primary papermill sludge effect on bermudagrass grown on a mine soil. Soil Sci. 157 (6), 389-397.

Feldkirchner, D.C., Wang, C., Gower, S.T., Kruger, E.L., Ferris, J., 2003. Effects of nutrient and paper mill biosolids amendments on the growth and nutrient status of hardwood forests. For. Ecol. Manag. 177 (1-3), 95-116, http://dx.doi. org/10.1016/S0378-1127(02)00318-3.

Field, G., Carroll, B., Fasth, W.,1996. Beneficial use of primary sludge from a recycle/tmp newsprint mill - a case study. In: Proceedings of TAPPI Environmental Conference. TAPPI Press, Atlanta, GA, USA, pp. 539-544

Fierro, A., Angers, D.A., Beauchamp, C.J., 1999. Restoration of ecosystem function in an abandoned sandpit: plant and soil responses to paper de-inking sludge. J. Appl. Ecol. 36 (2), 244-253, http://dx.doi.org/10.1046/j.1365-2664.1999. 00395.x.

Fierro, A., Norrie, J., Gosselin, A., Beauchamp, C.J., 1997. Deinking sludge influences biomass, nitrogen and phosphorus status of several grass and legume species. Can. J. Soil Sci. 77 (4), 693-702, http://dx.doi.org/10.4141/S96-114.

Filiatrault, P., Camiré, C., Norrie, J.P., Beauchamp, C.J., 2006. Effects of de-inking paper sludge on growth and nutritional status of alder and aspen. Resour. Conserv. Recycl. 48 (3), 209-226, http://dx.doi.org/10.1016/j.resconrec.2006. 02.001 .

Fischedick, M., Roy, J., Abdel-Aziz, A., Acquaye, A., Allwood, J.M., Ceron, J.-P., Geng, Y., Kheshgi, H., Lanza, A., Perczyk, D., Price, L., Santalla, E., Sheinbaum, C., Tanaka, K., 2014. Climate change 2014: mitigation of climate change. In: Edenhofer, O., Pichs-Madruga, R., Sokona, Y., Farahani, E., Kadner, S., Seyboth, K., Adler, A., Baum, I., Brunner, S., Eickemeier, P., Kriemann, B., Savolainen, J., Schlömer, S., von Stechow, C. Zwickel, T., Minx, J.C. (Eds.), Contribution of Working Group III to the Fifth Assessment Report of the Intergovernmental Panel on Climate Change. Cambridge University Press, Cambridge, United Kingdom and New York, NY, USA, pp. 739-810.

Flagan, R.C., Seinfeld, J.H., 1988. Fundamentals of Air Pollution Engineering. Prentice-Hall, Inc., Englewood Cliffs, NJ, USA, pp. 542.

Frei, K.M., Cameron, D., Jasmin, S., Stuart, P.R., 2006. Novel sludge drying process for cost-effective on-site sludge management. Pulp Pap. Can. 107 (4), $47-53$

Furness, D.T., Hoggett, L.A., Judd, S.J., 2000. Thermochemical treatment of sewage sludge. Water Environ. J. 14 (1), 57-65, http://dx.doi.org/10.1111/j.1747-6593. 2000.tb00227.x.

Fytili, D., Zabaniotou, A., 2008. Utilization of sewage sludge in EU application of old and new methods-a review. Renew. Sustain. Energy Rev. 12 (1), 116-140, http://dx.doi.org/10.1016/j.rser.2006.05.014.

Gagnon, B., Ziadi, N., 2012. Papermill biosolids and alkaline residuals affect crop yield and soil properties over nine years of continuous application. Can. J. Soil Sci. 92 (6), 917-930, http://dx.doi.org/10.4141/cjss2012-026.

Gagnon, B., Ziadi, N., Chantigny, M.H., Bélanger, G., Massé, D.I., 2012. Biosolids from treated swine manure and papermill residues affect corn fertilizer value. Agron. J. 104 (2), 483-492, http://dx.doi.org/10.2134/agronj2011.0327.

Gagnon, B., Ziadi, N., Côté, C., Foisy, M., 2010. Environmental impact of repeated applications of combined paper mill biosolids in silage corn production. Can. J. Soil Sci. 90 (1), 215-227, http://dx.doi.org/10.4141/CJSS09055.

Gallardo, F., Bravo, C., Briceño, G., Diez, M.C., 2010. Use of sludge from kraft mill wastewater treatment as improver of volcanic soils: effect on soil biological parameters. Rev. cienc. suelo nutr. veg. 10 (1), 48-61.

Gallardo, F., Cea, M., Tortella, G.R., Diez, M.C., 2012. Effect of pulp mill sludge on soil characteristics, microbial community and vegetal production of lolium perenne. J. Environ. Manag. 95 (Supplement), S193-S198, http://dx.doi.org/10. 1016/j.jenvman.2010.11.001.

Gavrilescu, D., 2008. Energy from biomass in pulp and paper mills. Environ. Eng Manag. J. 7 (5), 537-546.

Gea, T., Artola, A., Sánchez, A., 2005. Composting of de-inking sludge from the recycled paper manufacturing industry. Bioresour. Technol. 96 (10), 1161-1167, http://dx.doi.org/10.1016/j.biortech.2004.09.025.

Geng, X., Deng, J., Zhang, S.Y., 2007a. Paper mill sludge as a component of wood adhesive formulation. Holzforschung 61 (6), 688-692, http://dx.doi.org/10. 1515/HF.2007.112.

Geng, X., Zhang, S.Y., Deng, J., 2007b. Characteristics of paper mill sludge and its utilization for the manufacture of medium density fiberboard. Wood Fiber Sci. 39 (2), 345-351.

Gijzen, H.J., Derikx, P.J.L., Vogels, G.D., 1990. Application of rumen microorganisms for a high rate anaerobic digestion of papermill sludge. Biol. Wastes 32 (3), 169-179, http://dx.doi.org/10.1016/0269-7483(90)90046-U.

Gijzen, H.J., Schoenmakers, T.J.M., Caerteling, C.G.M., Vogels, G.D., 1988. Anaerobic degradation of papermill sludge in a two-phase digester containing rumen microorganisms and colonized polyurethane foam. Biotechnol. Lett. 10 (1), 61-66, http://dx.doi.org/10.1007/BF01030025.

Girones, J., Pardini, G., Vilaseca, F., Pelach, M.A., Mutje, P., 2010. Recycling of paper mill sludge as filler/reinforcement in polypropylene composites. J. Polym. Environ. 18 (3), 407-412, http://dx.doi.org/10.1007/s10924-010-0169-0.

Gloyna, E.F., Li, L., McBrayer, R.N., 1994. Engineering aspects of supercritical water oxidation. Water Sci. Technol. 30 (9), 1-10.
Gouvernement du Québec, 2012. Québec in Action Greener by 2020. 2013-2020 Climate Change Action Plan. Phase 1. Gouvernement du Québec, Quebec, QC, Canada, pp. 55

Gregorich, E.G., Rochette, P., VandenBygaart, A.J., Angers, D.A., 2005. Greenhouse gas contributions of agricultural soils and potential mitigation practices in Eastern Canada. Soil Tillage Res. 83 (1), 53-72, http://dx.doi.org/10.1016/j.still. 2005.02.009.

Guo, M., Song, W., Buhain, J., 2015. Bioenergy and biofuels: history, status, and perspective. Renew. Sustain. Energy Rev. 42, 712-725, http://dx.doi.org/10. 1016/j.rser.2014.10.013.

Hagelqvist, A., 2013. Batchwise mesophilic anaerobic co-digestion of secondary sludge from pulp and paper industry and municipal sewage sludge. Waste Manag. 33 (4), 820-824, http://dx.doi.org/10.1016/j.wasman.2012.11.002.

Hämäläinen, J.P., Aho, M.J., 1996. Conversion of fuel nitrogen through HCN and $\mathrm{NH}_{3}$ to nitrogen oxides at elevated pressure. Fuel 75 (12), 1377-1386, http:/ dx.doi.org/10.1016/0016-2361(96)00100-7.

Hamzeh, Y., Ashori, A., Marvast, E.H., Rashedi, K., Olfat, A.M., 2012. A comparative study on the effects of Coriolus versicolor on properties of HDPE/wood flour/paper sludge composites. Compos. B: Eng. 43 (5), 2409-2414, http://dx. doi.org/10.1016/j.compositesb.2011.11.043.

Hamzeh, Y., Ashori, A., Mirzaei, B., 2011. Effects of waste paper sludge on the physico-mechanical properties of high density polyethylene/wood flour composites. J. Polym. Environ. 19 (1), 120-124, http://dx.doi.org/10.1007/ s10924-010-0255-3.

He, X., Yao, L., Liang, Z., Ni, J., 2010. Paper sludge as a feasible soil amendment for the immobilization of $\mathrm{Pb}^{2+}$. J. Environ. Sci. 22 (3), 413-420, http://dx.doi.org/ 10.1016/S1001-0742(09)60123-6.

Henry, C.L., 1991. Nitrogen dynamics of pulp and paper sludge amendment to forest soils. Water Sci. Technol. 24 (3/4), 417-425.

Henry, C.L., Cole, D.W., Hinckley, T.M., Harrison, R.B., 1994. The use of municipal and pulp and paper sludges to increase production in forestry. J. Sustain. For. 1 (3), 41-55, http://dx.doi.org/10.1300/J091v01n03_04.

Hofman, M., Pietrzak, R., 2012. $\mathrm{NO}_{2}$ removal by adsorbents prepared from waste paper sludge. Chem. Eng. J. 183, 278-283, http://dx.doi.org/10.1016/j.cej.2011 12.077 .

Hossain, A.K., Ouadi, M., Siddiqui, S.U., Yang, Y., Brammer, J., Hornung, A., Kay, M. Davies, P.A., 2013. Experimental investigation of performance, emission and combustion characteristics of an indirect injection multi-cylinder $\mathrm{CI}$ engine fuelled by blends of de-inking sludge pyrolysis oil with biodiesel. Fuel 105, 135-142, http://dx.doi.org/10.1016/j.fuel.2012.05.007.

Huang, H.B., Du, H.H., Wang, W.H., Shi, J.Y., 2012. Characteristics of paper mill sludge-wood fiber-high-density polyethylene composites. Polym. Compos. 33 (9), 1628-1634, http://dx.doi.org/10.1002/pc.22287.

Hubbe, M.A., Nazhad, M., Sánchez, C., 2010. Composting as a way to convert cellulosic biomass and organic waste into high-value soil amendments: a review. Bioresources 5 (4), 2808-2854.

IEA GHG R\&D (International Energy Agency Greenhouse Gas R\&D Programme), 2000. Abatement of Other Greenhouse Gases - Nitrous Oxide. Report Number PH3/29., pp. 85.

Ilyina, A.D., Villarreal, S.J.A., Rivera, R.E., Garza, G.Y., Rodríguez, M.J., 2000. Using of BIODAC (adsorbent granules produced from paper industry residues) as carrier to microorganisms for soil inoculation. Vestnik Moskovskogo Universiteta. Khimiya 41 (6), 135-138.

IPCC (Intergovernmental panel on climate change), 2006. Guidelines for National Greenhouse Gas Inventories. Institute for Global Environmental Strategies, Hayama, Kanagawa, Japan.

IPCC, 2013. Climate change 2013: the physical science basis. In: Stocker, T.F., Qin, D., Plattner, G.-K., Tignor, M., Allen, S.K., Boschung, J., Nauels, A., Xia, Y., Bex, V., Midgley, P.M. (Eds.), Contribution of Working Group I to the Fifth Assessment Report of the Intergovernmental Panel on Climate Change. Cambridge University Press, Cambridge, United Kingdom and New York, NY, USA, p. 1535

IPPC (Integrated Pollution Prevention and Control), 2001. Reference Document on Best Available Techniques in the Pulp and Paper Industry. European Commission, pp. 475.

Ismail, H., Rusli, A., Rashid, A.A., 2006. The effect of filler loading and epoxidation on paper-sludge-filled natural rubber composites. Polym. Plast. Technol. Eng. 45 (4), 519-525, http://dx.doi.org/10.1080/03602550600553820.

Ismail, H., Bakar, S., Bakar, A.A., 2005. The effect of paper sludge content and size on the properties of polypropylene (PP)-ethylene propylene diene terpolymer (EPDM) composites. J. Reinf. Plast. Compos. 24 (2), 147-159, http://dx.doi.org/ $10.1177 / 0731684405042955$.

Jackson, M.J., Line, M.A., Wilson, S., Hetherington, S.J., 2000. Application of composted pulp and paper mill sludge to a young pine plantation. J. Environ. Qual. 29 (2), 407-414, http://dx.doi.org/10.2134/jeq2000. 00472425002900020006x.

Jiang, J., Ma, X., 2011. Experimental research of microwave pyrolysis about pape mill sludge. Appl. Therm. Eng. 31 (17-18), 3897-3903, http://dx.doi.org/10. 1016/j.applthermaleng.2011.07.037.

Jones, S.K., Rees, R.M., Kosmas, D., Ball, B.C., Skiba, U.M., 2006. Carbon sequestration in a temperate grassland; management and climatic controls. Soil Use Manag. 22 (2), 132-142, http://dx.doi.org/10.1111/j.1475-2743.2006.00036.x.

Joo, S.H., Monaco, F.D., Antmann, E., Chorath, P., 2015. Sustainable approaches for minimizing biosolids production and maximizing reuse options in sludge management: a review. J. Environ. Manag. 158, 133-145, http://dx.doi.org/10. 1016/j.jenvman.2015.05.014. 
Joshi, B., Bhatt, M.R., Sharma, D., Joshi, J., Malla, R., Sreerama, L., 2011. Lignocellulosic ethanol production: current practices and recent developments. Biotechnol. Mol. Biol. Rev. 6 (8), 172-182.

Kádár, Z., Vrije, T., Budde, M.A.W., Szengyel, Z., Réczey, K., Claassen, P.A.M., 2003. Hydrogen production from paper sludge hydrolysate. Appl. Biochem. Biotechnol. 107 (1-3), 557-566, http://dx.doi.org/10.1385/abab:107:1-3:557.

Kádár, Z., Vrije, T., Noorden, G.E., Budde, M.A.W., Szengyel, Z., Réczey, K., Claassen, P.A.M., 2004. Yields from glucose, xylose, and paper sludge hydrolysate during hydrogen production by the extreme thermophile Caldicellulosiruptor saccharolyticus. Appl. Biochem. Biotechnol. 114 (1-3), 497-508, http://dx.doi. org/10.1385/abab:114:1-3:497.

Kang, H.-Y., Park, S.-S., Rim, Y.-S., 2006. Preparation of activated carbon from pape mill sludge by KOH-activation. Korean J. Chem. Eng. 23 (6), 948-953, http://dx. doi.org/10.1007/s11814-006-0013-3.

Kang, L., Wang, W., Lee, Y.Y., 2010. Bioconversion of kraft paper mill sludges to ethanol by SSF and SSCF. Appl. Biochem. Biotechnol. 161 (1-8), 53-66, http:// dx.doi.org/10.1007/s12010-009-8893-4.

Kim, S., Kim, H.-J., Park, J.C., 2009. Application of recycled paper sludge and biomass materials in manufacture of green composite pallet. Resour. Conserv. Recycl. 53 (12), 674-679, http://dx.doi.org/10.1016/j.resconrec.2009.04.021.

Kothari, R., Singh, D.P., Tyagi, V.V., Tyagi, S.K., 2012. Fermentative hydrogen production - an alternative clean energy source. Renew. Sustain. Energy Rev. 16 (4), 2337-2346, http://dx.doi.org/10.1016/j.rser.2012.01.002.

Kraske, C.R., Fernandez, I.J., 1993. Biogeochemical responses of a forested watershed to both clearcut harvesting and papermill sludge application. J. Environ. Qual. 22 (4), 776-786, http://dx.doi.org/10.2134/jeq1993. 00472425002200040020x.

Krogerus, M., Tennander, E., Sivard, Å., 1999. Sludge Handling Practices in the Pulp and Paper Industry, Värmefrosk, Stockholm, Sweden., pp. 49.

Laird, D.A., Brown, R.C., Amonette, J.E., Lehmann, J., 2009. Review of the pyrolysis platform for coproducing bio-oil and biochar. Biofuels Bioprod. Biorefin. 3 (5) 547-562, http://dx.doi.org/10.1002/bbb.169.

Lalande, R., Gagnon, B., Simard, R.R., 2003. Papermill biosolid and hog manure compost affect short-term biological activity and crop yield of a sandy soil. Can. J. Soil Sci. 83 (4), 353-362, http://dx.doi.org/10.4141/S03-004.

Lark, N., Xia, Y., Qin, C.-G., Gong, C.S., Tsao, G.T., 1997. Production of ethanol from recycled paper sludge using cellulase and yeast, Kluveromyces marxianus. Biomass Bioenergy 12 (2), 135-143, http://dx.doi.org/10.1016/S09619534(96)00069-4.

Larney, F.J., Angers, D.A., 2012. The role of organic amendments in soil reclamation: a review. Can. J. Soil Sci. 92 (1), 19-38, http://dx.doi.org/10.4141/cjss2010-064.

Le Mer, J., Roger, P., 2001. Production, oxidation, emission and consumption of methane by soils: a review. Eur. J. Soil Biol. 37 (1), 25-50, http://dx.doi.org/10. 1016/S1164-5563(01)01067-6.

Leão, A.L., Cherian, B.M., de Souza, S.F., Sain, M., Narine, S., Caldeira, M.S., Toledo, M.A.S., 2012. Use of primary sludge from pulp and paper mills for nanocomposites. Mol. Cryst. Liq. Cryst. 556 (1), 254-263, http://dx.doi.org/10. 1080/15421406.2012.635974.

Legendre, B.L., Bischoff, K.P., Gravois, K.A., Hendrick, R.D., Arceneaux, A.E., 2004 Sugarcane yields and soil analysis following application of paper-mill sludge. J. Am. Soc. Sugar Cane Technol. 24, 60-69.

Lehmann, J., 2007. A handful of carbon. Nature 447 (7141), 143-144, http://dx.doi. org/10.1038/447143a.

Li, W., Yue, Q., Tu, P., Ma, Z., Gao, B., Li, J., Xu, X., 2011. Adsorption characteristics of dyes in columns of activated carbon prepared from paper mill sewage sludge. Chem. Eng. J. 178, 197-203, http://dx.doi.org/10.1016/j.cej.2011.10.049.

Likon, M., Černec, F., Saarela, J., Zimmie, T.F., Zule, J.,2009. Use of paper mill sludge for absorption of hydrophobic substances. In: 2nd International Conference on New Developments in Soil Mechanics and Geotechnical Engineering. Near East University, Nicosia, North Cyprus, Cyprus, pp. 526-533.

Likon, M., Saarela, J., 2012. The conversion of paper mill sludge into absorbent for oil spill sanitation - the life cycle assessment. Macromol. Symp. 320 (1), 50-56, http://dx.doi.org/10.1002/masy.201251006.

Likon, M., Trebše, P., 2012. Recent advances in paper mill sludge management. In: Show, K.-Y. (Ed.), InTech. Rijeka, Croatia, pp. 73-90.

Lister, S.K., Line, M.A., 2001. Potential utilisation of sewage sludge and paper mill waste for biosorption of metals from polluted waterways. Bioresour. Technol 79 (1), 35-39, http://dx.doi.org/10.1016/S0960-8524(01)00035-9.

Ljunggren Söderman, M., 2003. Recovering energy from waste in Sweden - a systems engineering study. Resour. Conserv. Recycl. 38 (2), 89-121, http://dx. doi.org/10.1016/S0921-3449(02)00103-9.

Lo, A., Liard, A., Velema, G., 1996. Use of primary sludge as a mulch in the forest plantations. Pulp Pap. Can. 97 (12), 161-164.

Lou, R., Wu, S., Lv, G., Yang, Q., 2012. Energy and resource utilization of deinking sludge pyrolysis. Appl. Energy 90 (1), 46-50, http://dx.doi.org/10.1016/j. apenergy.2010.12.025

Mabee, W., Roy, D.N., 2003. Modeling the role of papermill sludge in the organic carbon cycle of paper products. Environ. Rev. 11 (1), 1-16, http://dx.doi.org/10. 1139/a03-001.

Macyk, T.M., 1999. Land application of mechanical pulp mill sludges in Alberta: research and operational activities. Pulp Pap. Can. 100 (6), 34-37.

Magnusson, M., Alvfors, P., 2012. Biogas from mechanical pulping industry potential improvement for increased biomass vehicle fuels. In: Proceedings of ECOS 2012 - The 25th International Conference on Efficiency Cost Optimization Simulation and Environmental Impact of Energy Systems, Perugia, Italy, 54 (1-12).
Mahmood, T., Elliott, A., 2006. A review of secondary sludge reduction technologies for the pulp and paper industry. Water Res. 40 (11), 2093-2112, http://dx.doi. org/10.1016/j.watres.2006.04.001.

Mäkelä, M., Harju-Oksanen, M.-L., Watkins, G., Ekroos, A., Dahl, O., 2012. Feasibility assessment of inter-industry solid residue utilization for soil amendment trace element availability and legislative issues. Resour. Conserv. Recycl. 67 1-8, http://dx.doi.org/10.1016/j.resconrec.2012.06.012.

Mäkelä, M., Watkins, G., Dahl, O., Nurmesniemi, H., Poykio, R., 2010. Integration of solid residues from the steel and pulp and paper industries for forest soil amendment. J. Resid. Sci. Technol. 7 (4), 191-198.

Mäkinen, L., Ämmälä, A., Körkkö, M., Niinimäki, J., 2013. The effects of recovering fibre and fine materials on sludge dewatering properties at a deinked pulp mill. Resour. Conserv. Recycl. 73, 11-16, http://dx.doi.org/10.1016/j.resconrec. 2013.01.011.

Mari, E.L., Moran, M.S.R., Austria, C.O., 2009. Paper mill sludge as fiber additive for asphalt road pavement. Philipp. J. Sci. 138 (1), 29-36

Marques, S., Alves, L., Roseiro, J.C., Gírio, F.M., 2008. Conversion of recycled paper sludge to ethanol by SHF and SSF using Pichia stipitis. Biomass Bioenergy 32 (5), 400-406, http://dx.doi.org/10.1016/j.biombioe.2007.10.011.

Matsumura, Y., Minowa, T., Potic, B., Kersten, S.R.A., Prins, W., van Swaaij, W.P.M. van de Beld, B., Elliott, D.C., Neuenschwander, G.G., Kruse, A., Jerry Antal Jr., M., 2005. Biomass gasification in near- and super-critical water: status and prospects. Biomass Bioenergy 29 (4), 269-292, http://dx.doi.org/10.1016/j. biombioe.2005.04.006.

McGlashan, N., Shah, N., Caldecott, B., Workman, M., 2012. High-level techno-economic assessment of negative emissions technologies. Process Saf. Environ. Prot. 90 (6), 501-510, http://dx.doi.org/10.1016/j.psep.2012.10.004.

McLaren, D., 2012. A comparative global assessment of potential negative emissions technologies. Process Saf. Environ. Prot. 90 (6), 489-500, http://dx doi.org/10.1016/j.psep.2012.10.005.

MDDELCC (Ministère du Développement durable, de l'Environnement et de la Lutte contre les changements climatiques), 2015. Bilan annuel de conformité environnementale 2012. Secteur des pâtes et papiers. Gouvernement du Québec, Quebec, QC, Canada, pp. 74.

MDDEP (Ministère du Développement durable, de l'Environnement et des Parcs), 2011. Québec Residual Materials Management Policy. Gouvernement du Québec, Quebec, QC, Canada, pp. 13.

Méndez, A., Barriga, S., Fidalgo, J.M., Gascó, G., 2009a. Adsorbent materials from paper industry waste materials and their use in $\mathrm{Cu}(\mathrm{II})$ removal from water. J. Hazard. Mater. 165 (1-3), 736-743, http://dx.doi.org/10.1016/j.jhazmat.2008. 10.055 .

Méndez, A., Fidalgo, J.M., Guerrero, F., Gascó, G., 2009b. Characterization and pyrolysis behaviour of different paper mill waste materials. J. Anal. Appl. Pyrolysis 86 (1), 66-73, http://dx.doi.org/10.1016/j.jaap.2009.04.004.

Méndez, A., Barriga, S., Saa, A., Gascó, G., 2010. Removal of malachite green by adsorbents from paper industry waste materials. J. Therm. Anal. Calorim. 99 (3), 993-998, http://dx.doi.org/10.1007/s10973-010-0681-4.

Meyer, T., Edwards, E.A., 2014. Anaerobic digestion of pulp and paper mill wastewater and sludge. Water Res. 65, 321-349, http://dx.doi.org/10.1016/j. watres.2014.07.022.

MfE (Ministry for the Environment of New Zealand), 2010. The New Zealand Waste Strategy - Reducing Harm, Improving Efficiency. Publication number ME 1027 Wellington, New Zealand, pp. 12.

Migneault, S., Koubaa, A., Nadji, H., Riedl, B., Zhang, S.Y., Deng, J., 2010. Medium-density fiberboard produced using pulp and paper sludge from different pulping processes. Wood Fiber Sci. 42 (3), 292-303.

Migneault, S., Koubaa, A., Perré, P., 2014. Effect of fiber origin, proportion, and chemical composition on the mechanical and physical properties of wood-plastic composites. J. Wood Chem. Technol. 34 (4), 241-261, http://dx. doi.org/10.1080/02773813.2013.869604.

Migneault, S., Koubaa, A., Riedl, B., Nadji, H., Deng, J., Zhang, S.Y., 2011a. Binderless fiberboard made from primary and secondary pulp and paper sludge. Wood Fiber Sci. 43 (2), 180-193.

Migneault, S., Koubaa, A., Riedl, B., Nadji, H., Deng, J., Zhang, T.S.Y., 2011b. Potential of pulp and paper sludge as a formaldehyde scavenger agent in MDF resins. Holzforschung 65 (3), 403-409, http://dx.doi.org/10.1515/hf.2011.039.

Miller-Robbie, L., Ulrich, B.A., Ramey, D.F., Spencer, K.S., Herzog, S.P., Cath, T.Y. Stokes, J.R., Higgins, C.P., 2015. Life cycle energy and greenhouse gas assessment of the co-production of biosolids and biochar for land application. J. Clean. Prod. 91, 118-127, http://dx.doi.org/10.1016/j.jclepro.2014.12.050.

Mizuno, O., Dinsdale, R., Hawkes, F.R., Hawkes, D.L., Noike, T., 2000. Enhancement of hydrogen production from glucose by nitrogen gas sparging. Bioresour. Technol. 73 (1), 59-65, http://dx.doi.org/10.1016/S0960-8524(99)00130-3.

Monte, M.C., Fuente, E., Blanco, A., Negro, C., 2009. Waste management from pulp and paper production in the European Union. Waste Manag. 29 (1), 293-308, http://dx.doi.org/10.1016/j.wasman.2008.02.002.

Morales, M., Quintero, J., Conejeros, R., Aroca, G., 2015. Life cycle assessment of lignocellulosic bioethanol: environmental impacts and energy balance. Renew. Sustain. Energy Rev. 42, 1349-1361, http://dx.doi.org/10.1016/j.rser.2014.10. 097.

Moreau, A., Montplaisir, D., Sparling, R., Barnabé, S., 2015. Hydrogen, ethanol and cellulase production from pulp and paper primary sludge by fermentation with Clostridium thermocellum. Biomass Bioenergy 72, 256-262, http://dx.doi. org/10.1016/j.biombioe.2014.10.028.

Mtui, G.Y.S., 2009. Recent advances in pretreatment of lignocellulosic wastes and production of value added products. Afr. J. Biotechnol. 8 (8), 1398-1415. 
Murray, A., Horvath, A., Nelson, K.L., 2008. Hybrid life-cycle environmental and cost inventory of sewage sludge treatment and end-use scenarios: a case study from China. Environ. Sci. Technol. 42 (9), 3163-3169, http://dx.doi.org/10. 1021/es702256w.

N'Dayegamiye, A., 2006. Mixed paper mill sludge effects on corn yield, nitrogen efficiency, and soil properties. Agron. J. 98 (6), 1471-1478, http://dx.doi.org/10. 2134/agronj2005.0339.

N'Dayegamiye, A., 2009. Soil properties and crop yields in response to mixed paper mill sludges, dairy cattle manure, and inorganic fertilizer application. Agron. J. 101 (4), 826-835, http://dx.doi.org/10.2134/agronj2008.0170x.

Nanda, S., Azargohar, R., Dalai, A.K., Kozinski, J.A., 2015. An assessment on the sustainability of lignocellulosic biomass for biorefining. Renew. Sustain. Energy Rev. 50, 925-941, http://dx.doi.org/10.1016/j.rser.2015.05.058.

Navaee-Ardeh, S., Bertrand, F., Stuart, P.R., 2006. Emerging biodrying technology for the drying of pulp and paper mixed sludges. Dry. Technol. 24 (7), 863-878, http://dx.doi.org/10.1080/07373930600734026.

NCASI (National Council for Air and Stream Improvement), 2005. Calculation Tools for Estimating Greenhouse Gas Emissions from Pulp and Paper Mills. Report Version 1.1. A Project of the Climate Change Working Group of the International Council of Forest and Paper Associations (ICFPA). Research Triangle Park, NC, USA., pp. 140.

Nigam, P.S., Singh, A., 2011. Production of liquid biofuels from renewable resources. Prog. Energy Combust. Sci. 37 (1), 52-68, http://dx.doi.org/10.1016/ j.pecs.2010.01.003.

Noike, T., Takabatake, H., Mizuno, O., Ohba, M., 2002. Inhibition of hydrogen fermentation of organic wastes by lactic acid bacteria. Int. J. Hydrogen Energy 27 (11-12), 1367-1371, http://dx.doi.org/10.1016/S0360-3199(02)00120-9.

Norrie, J., Gosselin, A., 1996. Paper sludge amendments for turfgrass. HortScience 31 (6), 957-960

O'Connor, M., Garnier, G., Batchelor, W., 2014. Life cycle assessment comparison of industrial effluent management strategies. J. Clean. Prod. 79, 168-181, http:// dx.doi.org/10.1016/j.jclepro.2014.05.066.

Ochoa de Alda, J.A.G., 2008. Feasibility of recycling pulp and paper mill sludge in the paper and board industries. Resour. Conserv. Recycl. 52 (7), 965-972, http://dx.doi.org/10.1016/j.resconrec.2008.02.005.

Ojeda, K., Sánchez, E., El-Halwagi, M., Kafarov, V., 2011. Exergy analysis and process integration of bioethanol production from acid pre-treated biomass: comparison of SHF, SSF and SSCF pathways. Chem. Eng. J. 176-177, 195-201, http://dx.doi.org/10.1016/j.cej.2011.06.083.

Oral, J., Sikula, J., Puchyr, R., Hajny, Z., Stehlik, P., Bebar, L., 2005. Processing of waste from pulp and paper plant. J. Clean. Prod. 13 (5), 509-515, http://dx.doi. org/10.1016/j.jclepro.2003.09.005.

Ouadi, M., Brammer, J., Hornung, A., Kay, M., 2012. Waste to power. Tappi J. 11 (2), 55-64.

Ouadi, M., Brammer, J.G., Yang, Y., Hornung, A., Kay, M., 2013. The intermediate pyrolysis of de-inking sludge to produce a sustainable liquid fuel. J. Anal. Appl. Pyrolysis 102, 24-32, http://dx.doi.org/10.1016/j.jaap.2013.04.007.

Peng, L., Chen, Y., 2011. Conversion of paper sludge to ethanol by separate hydrolysis and fermentation (SHF) using Saccharomyces cerevisiae. Biomass Bioenergy 35 (4), 1600-1606, http://dx.doi.org/10.1016/j.biombioe.2011.01 059.

Pervaiz, M., Sain, M., 2011. Protein extraction from secondary sludge of paper mill wastewater and its utilization as a wood adhesive. Bioresources 6 (2), 961-970.

Pervaiz, M., Sain, M., 2012. High-yield protein recovery from secondary sludge of paper mill effluent and its characterization. Bioresources 7 (3), 2933-2947.

Pervaiz, M., Sain, M., 2015. Recycling of paper mill biosolids: a review on current practices and emerging biorefinery initiatives. CLEAN - Soil Air Water 43 (6), 919-926, http://dx.doi.org/10.1002/clen.201400590.

Piearce, T.G., Boone, G.C., 1998. Responses of invertebrates to paper sludge application to soil. Appl. Soil Ecol. 9 (1-3), 393-397, http://dx.doi.org/10.1016/ S0929-1393(98)00095-X.

Piearce, T.G., Budd, T., Hayhoe, J.M., Sleep, D., Clasper, P.J., 2003. Earthworms of a land restoration site treated with paper mill sludge. In the 7th international symposium on earthworm ecology, Cardiff, Wales, UK, 2002. Pedobiologia 47 (5-6), 792-795, http://dx.doi.org/10.1078/0031-4056-00260.

Pikon, K., Gaska, K., 2010. Greenhouse gas emission mitigation relevant to changes in municipal solid waste management system. J. Air Waste Manag. Assoc. 60 (7), 782-788, http://dx.doi.org/10.3155/1047-3289.60.7.782.

Poeschl, M., Ward, S., Owende, P., 2012. Environmental impacts of biogas deployment - Part I: Life cycle inventory for evaluation of production process emissions to air. J. Clean. Prod. 24, 168-183, http://dx.doi.org/10.1016/j. jclepro.2011.10.039.

Pokhrel, D., Viraraghavan, T., 2004. Treatment of pulp and paper mill wastewater-a review. Sci. Total Environ. 333 (1-3), 37-58, http://dx.doi.org/ 10.1016/j.scitotenv.2004.05.017.

PRé Consultants, 2014. Simapro 8, Amersfoort, The Netherlands.

Price, G.W., Voroney, R.P., 2007. Papermill biosolids effect on soil physical and chemical properties. J. Environ. Qual. 36 (6), 1704-1714, http://dx.doi.org/10. 2134/jeq2007.0043.

Price, G.W., Voroney, R.P., 2008. Response to annual applications of de-inked papermill biosolids by field earthworms on three agricultural soils. Appl. Soil Ecol. 38 (3), 230-238, http://dx.doi.org/10.1016/j.apsoil.2007.10.014.

Qiao, X., Zhang, Y., Zhang, Y., 2004. Maleic anhydride grafted polypropylene as a coupling agent for polypropylene composites filled with ink-eliminated waste paper sludge flour. J. Appl. Polym. Sci. 91 (4), 2320-2325, http://dx.doi.org/10. 1002/app.13370.
Quaye, A.K., Volk, T.A., Hafner, S., Leopold, D.J., Schirmer, C., 2011. Impacts of paper sludge and manure on soil and biomass production of willow. Biomass Bioenergy 35 (7), 2796-2806, http://dx.doi.org/10.1016/j.biombioe.2011.03. 008.

Quintern, M., 2014. Full scale vermicomposting and land utilisation of pulpmill solids in combination with municipal biosolids (sewage sludge). In: Brebbia, C.A., Passerini, G., Itoh, H. (Eds.), 7th International Conference on Waste Management and the Environment. Wit Press, Ashurst, Southampton, UK, Ancona, Italy, http://dx.doi.org/10.2495/WM140061.

Rabinowitz, B., Stephenson, R., 2005. Improving anaerobic digester efficiency by homogenization of waste activated sludge. Proceedings of the Water Environment Federation 2005: Session 31 through Session 40 (13) 2752-2771, http://dx.doi.org/10.2175/193864705783865578.

Raitio, L., 1992. The properties of deinking sludge. Paperi ja Puu 74 (2), 132-138.

Rama Mohan, S., 2015. Structure and growth of research on biohydrogen generation using wastewater. Int. J. Hydrogen Energy, http://dx.doi.org/10. 1016/j.ijhydene.2015.08.072, in press.

Rashid, M.T., Barry, D., Goss, M., 2006. Paper mill biosolids application to agricultural lands: benefits and environmental concerns with special reference to situation in Canada. Soil Environ. 25 (2), 85-98.

Rato Nunes, J., Cabral, F., López-Piñeiro, A., 2008. Short-term effects on soil properties and wheat production from secondary paper sludge application on two Mediterranean agricultural soils. Bioresour. Technol. 99 (11), 4935-4942, http://dx.doi.org/10.1016/j.biortech.2007.09.016.

Reckamp, J.M., Garrido, R.A., Satrio, J.A., 2014. Selective pyrolysis of paper mill sludge by using pretreatment processes to enhance the quality of bio-oil and biochar products. Biomass Bioenergy 71, 235-244, http://dx.doi.org/10.1016/j. biombioe.2014.10.003.

Ribeiro, P., Albuquerque, A., Quinta-Nova, L., Cavaleiro, V., 2010. Recycling pulp mill sludge to improve soil fertility using GIS tools. Resour. Conserv. Recycl. 54 (12), 1303-1311, http://dx.doi.org/10.1016/j.resconrec.2010.05.009.

Rochette, P., Worth, D.E., Lemke, R.L., McConkey, B.G., Pennock, D.J., Wagner-Riddle, C., Desjardins, R.J., 2008. Estimation of $\mathrm{N}_{2} \mathrm{O}$ emissions from agricultural soils in Canada. I. Development of a country-specific methodology Can. J. Soil Sci. 88 (5), 641-654, http://dx.doi.org/10.4141/CJSS07025.

Ruohonen, P., Hippinen, I., Tuomaala, M., Ahtila, P., 2010. Analysis of alternative secondary heat uses to improve energy efficiency - case: a Finnish mechanical pulp and paper mill. Resour. Conserv. Recycl. 54 (5), 326-335, http://dx.doi. org/10.1016/j.resconrec.2009.07.002.

Saha, M., Eskicioglu, C., Marin, J., 2011. Microwave, ultrasonic and chemo-mechanical pretreatments for enhancing methane potential of pulp mill wastewater treatment sludge. Bioresour. Technol. 102 (17), 7815-7826, http://dx.doi.org/10.1016/j.biortech.2011.06.053.

Sawatdeenarunat, C., Surendra, K.C., Takara, D., Oechsner, H., Khanal, S.K., 2015. Anaerobic digestion of lignocellulosic biomass: challenges and opportunities. Bioresour. Technol. 178, 178-186, http://dx.doi.org/10.1016/j.biortech.2014. 09.103.

Shabna, A., Kale, R.D., Nair, P., 2011. The potential bioconversion of paper waste into bioplastics and biofuel. Biotechnol. Bioinf. Bioeng. 1 (3), 337-342.

Sharma, S., Ghoshal, S.K., 2015. Hydrogen the future transportation fuel: from production to applications. Renew. Sustain. Energy Rev. 43, 1151-1158, http:// dx.doi.org/10.1016/j.rser.2014.11.093.

Shin, D., Jang, S., Hwang, J., 2005. Combustion characteristics of paper mill sludge in a lab-scale combustor with internally cycloned circulating fluidized bed. Waste Manag. 25 (7), 680-685, http://dx.doi.org/10.1016/j.wasman.2004.12.016.

Shipitalo, M.J., Bonta, J.V., 2008. Impact of using paper mill sludge for surface-mine reclamation on runoff water quality and plant growth. J. Environ. Qual. 37 (6), 2351-2359, http://dx.doi.org/10.2134/jeq2007.0648.

Simard, R.R., Baziramakenga, R., Yelle, S., Coulombe, J., 1998. Effects of de-inking paper sludges on soil properties and crop yields. Can. J. Soil Sci. 78 (4), 689-697, http://dx.doi.org/10.4141/S98-003.

Son, J., Yang, H.-S., Kim, H.-J., 2004. Physico-mechanical properties of paper sludge-thermoplastic polymer composites. J. Thermoplast. Compos. Mater. 17 (6), 509-522, http://dx.doi.org/10.1177/0892705704038471.

Soucy, J., Koubaa, A., Migneault, S., Riedl, B., 2014. The potential of paper mill sludge for wood-plastic composites. Ind. Crops Prod. 54, 248-256, http://dx. doi.org/10.1016/j.indcrop.2014.01.013.

Stephenson, R., Rabinowitz, B., Laliberte, S., Elson, P.,2005. Teaching an old digester new tricks: full-scale demonstration of the microsludge process to liquefy municipal waste activated sludge. In: Proceedings of the Water Environment Federation, Residuals and Biosolids Management. Water Environment Federation, Covington, KY, USA., pp. 386-411.

Stoica, A., Sandberg, M., Holby, O., 2009. Energy use and recovery strategies within wastewater treatment and sludge handling at pulp and paper mills. Bioresour Technol. 100 (14), 3497-3505, http://dx.doi.org/10.1016/j.biortech.2009.02. 041.

Strezov, V., Evans, T.J., 2009. Thermal processing of paper sludge and characterisation of its pyrolysis products. Waste Manag. 29 (5), 1644-1648, http://dx.doi.org/10.1016/j.wasman.2008.11.024.

Svanström, M., Modell, M., Tester, J., 2004. Direct energy recovery from primary and secondary sludges by supercritical water oxidation. Water Sci. Technol. 49 (10), 201-208.

Swedish EPA (Environmental Protection Agency), 2015. National Inventory Report Sweden 2015. Greenhouse Gas Emission Inventories 1990-2013. Submitted Under the United Nations Framework Convention on Climate Change and the Kyoto Protocol, Stockholm, Sweden., pp. 505. 
SYLVIS, 2009. The Biosolids Emissions Assessment Model (BEAM): A Method for Determining Greenhouse Gas Emissions from Canadian Biosolids Management Practices. New Westminster, BC, Canada., pp. 178.

Taramian, A., Doosthoseini, K., Mirshokraii, S.A., Faezipour, M., 2007. Particleboard manufacturing: an innovative way to recycle paper sludge. Waste Manag. 27 (12), 1739-1746, http://dx.doi.org/10.1016/j.wasman.2006.09.009.

Thangarajan, R., Bolan, N.S., Tian, G., Naidu, R., Kunhikrishnan, A., 2013. Role of organic amendment application on greenhouse gas emission from soil. Sci. Total Environ. 465, 72-96, http://dx.doi.org/10.1016/j.scitotenv.2013.01.031.

Thompson, G., Swain, J., Kay, M., Forster, C.F., 2001. The treatment of pulp and paper mill effluent: a review. Bioresour. Technol. 77 (3), 275-286, http://dx. doi.org/10.1016/S0960-8524(00)00060-2.

Thornley, P., Gilbert, P., Shackley, S., Hammond, J., 2015. Maximizing the greenhouse gas reductions from biomass: the role of life cycle assessment. Biomass Bioenergy 81, 35-43, http://dx.doi.org/10.1016/j.biombioe.2015.05. 002.

Tong, W.-Y., Fu, X.-Y., Lee, S.-M., Yu, J., Liu, J.-W., Wei, D.-Z., Koo, Y.-M., 2004. Purification of $\mathrm{L}(+)$-lactic acid from fermentation broth with paper sludge as a cellulosic feedstock using weak anion exchanger Amberlite IRA-92. Biochem. Eng. J. 18 (2), 89-96, http://dx.doi.org/10.1016/S1369-703X(03)00170-0.

Trépanier, L., Thériault, G., Caron, J., Gallichand, J., Yelle, S., Beauchamp, C.J.,1996. Impact of deinking sludge amendment on agricultural soil quality. In: Proceedings of TAPPI Environmental Conference. TAPPI Press, Atlanta, GA, pp. 529-537.

Tripathy, S., Bhattacharyya, P., Equeenuddin, S.M., Kim, K., Kulkarni, H.D., 2008. Comparison of microbial indicators under two water regimes in a soil amended with combined paper mill sludge and decomposed cow manure. Chemosphere 71 (1), 168-175, http://dx.doi.org/10.1016/j.chemosphere.2007.10.042.

Tsupari, E., Monni, S., Tormonen, K., Pellikka, T., Syri, S., 2007. Estimation of annual $\mathrm{CH}_{4}$ and $\mathrm{N}_{2} \mathrm{O}$ emissions from fluidised bed combustion: an advanced measurement-based method and its application to Finland. Int. J. Greenh. Gas Control 1 (3), 289-297, http://dx.doi.org/10.1016/s1750-5836(07)00019-9.

US EPA (United States Environmental Protection Agency), 1994. A Guide to the Biosolids Risk Assessments for the EPA Part 503 Rule. Washington, DC, USA.

Valdez-Vazquez, I., Sparling, R., Risbey, D., Rinderknecht-Seijas, N., Poggi-Varaldo, H.M., 2005. Hydrogen generation via anaerobic fermentation of paper mill wastes. Bioresour. Technol. 96 (17), 1907-1913, http://dx.doi.org/10.1016/j. biortech.2005.01.036.

Velis, C.A., Longhurst, P.J., Drew, G.H., Smith, R., Pollard, S.J.T., 2009. Biodrying for mechanical - biological treatment of wastes: a review of process science and engineering. Bioresour. Technol. 100 (11), 2747-2761, http://dx.doi.org/10. 1016/j.biortech.2008.12.026.

Vera, C.J., Servello, F.A., 1994. Effects of paper mill sludge in spruce-fir forests on wildlife in Maine. J. Wildl. Manag. 58 (4), 719-727, http://dx.doi.org/10.2307/ 3809686.

Vijayakumar, J., Aravindan, R., Viruthagiri, T., 2008. Recent trends in the production, purification and application of lactic acid. Chem. Biochem. Eng. Q. 22 (2), 245-264.

Wang, H., Brown, S., Magesan, G., Slade, A., Quintern, M., Clinton, P., Payn, T., 2008 Technological options for the management of biosolids. Environ. Sci. Pollut. Res. Int. 15 (4), 308-317, http://dx.doi.org/10.1007/s11356-008-0012-5.

WBCSD/WRI (World Business Council for Sustainable Development/World Resources Institute), 2005. The Greenhouse Gas Protocol. The GHG Protocol for Project Accounting. Geneva, Switzerland and Washington, DC, USA., pp. 144.

Wood, N., Tran, H., Master, E., 2009. Pretreatment of pulp mill secondary sludge for high-rate anaerobic conversion to biogas. Bioresour. Technol. 100 (23), 5729-5735, http://dx.doi.org/10.1016/j.biortech.2009.06.062.

Wood, S., Cowie, C., 2004. A Review of Greenhouse Gas Emission Factors for Fertiliser Production. International Energy Agency (IEA) Bioenergy Task 38. International Energy Agency, pp. 20.
Xing, S., Riedl, B., Deng, J., Nadji, H., Koubaa, A., 2013. Potential of pulp and paper secondary sludge as co-adhesive and formaldehyde scavenger for particleboard manufacturing. Eur. J. Wood Wood Prod. 71 (6), 705-716, http:// dx.doi.org/10.1007/s00107-013-0729-9.

Xing, S., Riedl, B., Koubaa, A., Deng, J., 2012a. Mechanical and physical properties of particleboard made from two pulp and paper mill secondary sludges. World J. Eng. 9 (1), 31-36, http://dx.doi.org/10.1260/1708-5284.9.1.31.

Xing, S., Riedl, B., Koubaa, A., Deng, J., 2012b. Optimal percentage of pulp and paper mill secondary sludge incorporated in particleboard. In: Proceedings of the 55th International Convention of Society of Wood Science and Technology, Beijng, China, SP-15.

$\mathrm{Xu}, \mathrm{C}$., Lancaster, J., 2008. Conversion of secondary pulp/paper sludge powder to liquid oil products for energy recovery by direct liquefaction in hot-compressed water. Water Res. 42 (6-7), 1571-1582, http://dx.doi.org/10. 1016/j.watres.2007.11.007.

Xu, X., Antal, M.J., 1998. Gasification of sewage sludge and other biomass for hydrogen production in supercritical water. Environ. Prog. 17 (4), 215-220, http://dx.doi.org/10.1002/ep.670170411.

Xu, X., Matsumura, Y., Stenberg, J., Antal, M.J., 1996. Carbon-catalyzed gasification of organic feedstocks in supercritical water. Ind. Eng. Chem. Res. 35 (8) 2522-2530, http://dx.doi.org/10.1021/ie950672b.

Yan, S., Sagoe-Crentsil, K., Shapiro, G., 2011. Reuse of de-inking sludge from wastepaper recycling in cement mortar products. J. Environ. Manag. 92 (8), 2085-2090, http://dx.doi.org/10.1016/j.jenvman.2011.03.028.

Yanik, J., Ebale, S., Kruse, A., Saglam, M., Yüksel, M., 2007. Biomass gasification in supercritical water: Part 1. Effect of the nature of biomass. Fuel 86 (15), 2410-2415, http://dx.doi.org/10.1016/j.fuel.2007.01.025.

Yue, Z.-B., Li, W.-W., Yu, H.-Q., 2013. Application of rumen microorganisms for anaerobic bioconversion of lignocellulosic biomass. Bioresour. Technol. 128, 738-744, http://dx.doi.org/10.1016/j.biortech.2012.11.073.

Zacchi, G., Axelsson, A., 1989. Economic evaluation of preconcentration in production of ethanol from dilute sugar solutions. Biotechnol. Bioeng. 34 (2), 223-233, http://dx.doi.org/10.1002/bit.260340211.

Zang, Y., Li, Y., Wang, C., Zhang, W., Xiong, W., 2015. Towards more accurate life cycle assessment of biological wastewater treatment plants: a review. J. Clean. Prod., http://dx.doi.org/10.1016/j.jclepro.2015.05.060.

Zhang, J., Lynd, L.R., 2010. Ethanol production from paper sludge by simultaneous saccharification and co-fermentation using recombinant xylose-fermenting microorganisms. Biotechnol. Bioeng. 107 (2), 235-244, http://dx.doi.org/10. 1002/bit.22811.

Zhang, L., Champagne, P., Xu, C., 2011. Bio-crude production from secondary pulp/paper-mill sludge and waste newspaper via co-liquefaction in hot-compressed water. Energy 36 (4), 2142-2150, http://dx.doi.org/10.1016/j. energy.2010.05.029.

Zhang, L., Xu, C., Champagne, P., 2010. Energy recovery from secondary pulp/paper-mill sludge and sewage sludge with supercritical water treatment. Bioresour. Technol. 101 (8), 2713-2721, http://dx.doi.org/10.1016/j.biortech. 2009.11.106.

Zhu, M.-J., Zhu, Z.-S., Li, X.-H., 2011. Bioconversion of paper sludge with low cellulosic content to ethanol by separate hydrolysis and fermentation. Afr. J. Biotechnol. 10 (66), 15072-15083, http://dx.doi.org/10.5897/AJB11.1644.

Ziadi, N., Gagnon, B., Nyiraneza, J., 2013. Crop yield and soil fertility as affected by papermill biosolids and liming by-products. Can. J. Soil Sci. 93 (3), 319-328, http://dx.doi.org/10.4141/cjss2012-129.

Zibilske, L.M., Clapham, W.M., Rourke, R.V., 2000. Multiple applications of paper mill sludge in an agricultural system: soil effects. J. Environ. Qual. 29 (6), 1975-1981, http://dx.doi.org/10.2134/jeq2000.00472425002900060034x.

Zitomer, D.H., Adhikari, P., Heisel, C., Dineen, D., 2008. Municipal anaerobic digesters for codigestion, energy recovery, and greenhouse gas reductions. Water Environ. Res. 80 (3), 229-237, http://dx.doi.org/10.2175/ $106143007 \times 221201$. 